\title{
RockING THE TAX CODE: A CASE STUdy OF EMPLOYMENT-RELATED CHILD-CARE EXPENDITURES
}

\author{
Mary Louise Fellows ${ }^{\dagger}$
}

INTRODUCTION 308

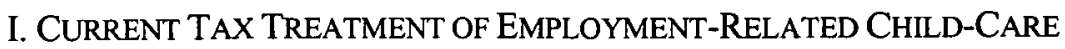

EXPENDITURES 312

II. THE HISTORY OF WAGED CHILDCARE 314

A. Domestic Work from the Nineteenth Century Until World War II......... 316

1. The Respectability/Degeneracy Distinction. 316

2. The Cult of Respectability in the

Last Half of the Nineteenth Century.

3. Geographic Variations from the Last Half of the Nineteenth Century

Until World War II: Class, Gender, and Racial Stratification........ 323

4. Social Programs During the First Half of the Twentieth Century .... 330 B. The Market for Child-Care Services from World War II Through the ... 334 Present Day

1. The Reconfiguration of the Respectability/Degeneracy Distinction 334

2. The Federal Government's Involvement in Childcare. 338

3. Contemporary "Solutions" to Providing Childcare for

Middle-Class Families

4. Summary of the History of Waged Childcare

III. EMPLOYMENT-RELATED CHILD-CARE EXPENDITURES AND TRADITIONAL

TAX PRINCIPLES: THE MYTH OF OBJECTIVITY …....................................... 354

A. The Business/Personal Distinction ......................................................... 354

B. Imputed Income ................................................................................. 357

C. The Interrelationship Between the Business/Personal Distinction and Imputed Income ................................................................................... 360

D. The Politics of the Invisibility of the Child-Care Worker in

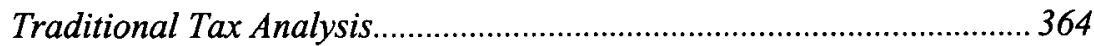

IV. EMPLOYMENT-RELATED CHILD-CARE EXPENDITURES AND TRADITIONAL

TAX LITERATURE: THE MYTH OF OBJECTIVITY ............................................ 367

A. Henry Simons: The Definition of Income ............................................... 369

B. Smith v. Commissioner: Applying "Accepted Principles "..................... 374

C. Stanley Surrey: The Tax Expenditure Budget......................................... 378

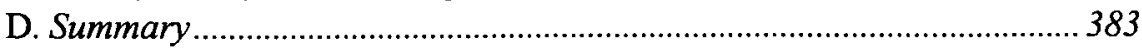

V. EMPLOYMENT-RELATED CHILD-CARE EXPENDITURES UNDER THE TAX LAW:

$\dagger$ Everett Fraser Professor of Law, University of Minnesota. I would like to thank Beverly Balos, Karen Brown, Gwen Handelman, Mary Heen, Sherene Razack, Denise Roy, and Nancy Staudt for their helpful comments on various drafts of this piece. I am also grateful for the opportunity to have presented this article at the Critical Tax Theory Workshop, sponsored by the State University of New York at Buffalo and the Women Studies Colloquium, sponsored by the Women Studies Department at Comell University. 


\section{INTRODUCTION}

Through an examination of the tax law's treatment of child-care expenditures, I intend to show both how the current tax law facilitates class, gender, and race subordination and how it could be designed to disrupt it. ${ }^{1}$ By looking at the tax law's treatment of employment-related child-care expenditures, I will make the argument that a comprehensive tax analysis requires not only an examination of the well-recognized issues of equity, administrability, and economic rationality, ${ }^{2}$ but also consideration of other issues of social justice-specifically, consideration of the implications of economic exploitation, racism, and sexism on economic arrangements. I appreciate that there is currently little consensus among policymakers for the need to include what I will call the antisubordination principle in tax reform deliberations. ${ }^{3} \mathrm{~A}$ review of child-care expenditures offers the opportunity to demonstrate how the antisubordination principle can further social justice while enhancing our general understanding of the tax law and producing reforms that advance the traditional goals of equity, administrability, and economic rationality.

Currently, the Internal Revenue Code (Code) includes two alternative provisions, sections 21 and 129 , designed to reduce the tax liability for taxpayers incurring employment-related child-care costs. ${ }^{4}$ These provisions promise to

1. I have intentionally chosen the term subordination rather than discrimination for two reasons. First, I want to avoid confusing the marketplace arrangements that I will be critiquing with the discriminatory acts that the law already prohibits. Some of the arrangements that I will describe may be illegal, but many of the others are not, despite their discriminatory and subordinating effect. The second reason I am using the term subordination is to encourage the reader to consider the multiple ways in which domination of a group occurs. In this regard, my thinking is informed by the work of Iris Marion Young, who organizes the concepts and conditions that produce oppression into five categories: exploitation, marginalization, powerlessness, cultural imperialism, and violence. See IRIS MARION YOUNG, JUSTICE AND THE POLITICS OF DIFFERENCE 39-65 (1990).

Subordination in the marketplace and the tax law based on disability or sexual orientation must also be investigated. The analysis of both these forms of discrimination requires a substantial amount of background analysis to show how both are related integrally to class, gender, and race and to show how the omission of specific provisions recognizing the specific needs of persons with disabilities and of those in the bisexual, lesbian, gay, and transgender communities is one of the ways discrimination occurs. For that reason, I have decided to limit my introduction of an antisubordination principle to tax policy discussions to consideration of issues of class, gender, and race and to defer questions involving disability and sexual orientation. I acknowledge that the different systems of subordination are related integrally and inseparably and appreciate that I am presenting only a fragment of an antisubordination tax framework by looking exclusively at class, gender, and race issues.

2. See STAFF OF JOINT COMM. ON TAXation, 99TH CONG., GENERAL EXPLANATION OF THE TAX REFORM Act of 1986, 6-11 (Comm. Print 1987); Staff of Jont EConomic COMM., 88Th CONG., THE FEderal TaX System: FaCTS AND PROBlems 30-42 (Comm. Print 1964).

3. In referring to persons who engage in discussions of tax policy, I will use the term policymakers. I include within that term academics, researchers from privately funded organizations, elected officials, and others working in either the executive or legislative branches of government.

4. I.R.C. $\S \S 21,129$ (1994) [hereinafter all citations to the Code will omit the year]. Sections 21 and 129 also reduce the tax liability for taxpayers incurring employment-related care expenditures for dependents other than their minor children. A complete analysis of dependent-care expenditures for persons other than minor 
show the useful application of the antisubordination principle for two reasons. One reason is that the provisions are frequently the subject of a debate in which both proponents and opponents of the provisions rely on one of the tax law's most basic tax tools-the business/personal distinction-to reach different conclusions. ${ }^{5}$ Opponents urge Congress not to make any provision in the Code for child-care expenditures because the expenditures are a form of consumption. ${ }^{6}$ In contrast, proponents argue that current law should be expanded to provide tax relief for child-care costs incurred to permit a parent or parents to engage in business either as an employee or entrepreneur. ${ }^{7}$ If, with regard to a particular tax issue like childcare, the business/personal distinction does not produce predictable and widely accepted results, that suggests that the antisubordination principle may prove useful.

The inadequacy of the tax analysis of child-care expenditures suggests a second reason why the antisubordination principle may be applied profitably to this area of tax law. The conventional tax analysis of child-care provisions focuses exclusively on the effects of the provisions on the parents, usually mothers, to engage in waged work. Little or no consideration is given in traditional tax analysis on the effects of the provisions on the waged child-care worker. ${ }^{8}$ For example, Anne Alstott, who considers the tax treatment of childcare expenditures in a recent article devoted to considering what tax policy might contribute to a feminist legal agenda, analyzes the tax provisions exclusively from the viewpoint of the consumer of child-care services. ${ }^{9}$ Even though Professor Alstott throughout her article is dedicated to evaluating the tax law by considering the different family and economic circumstances of women, ${ }^{10}$ childcare workers are invisible in her analysis. This omission is particularly confounding because the economic arrangement that is the very subject of taxation is the purchase of child-care services. Nevertheless, the focus of attention in tax discussions is the parent's decision to engage in unwaged labor in the home or waged labor in the marketplace. The antisubordination principle,

children would require an investigation of demographic changes within the American family, medicare and medicaid policies, and a range of disability-rights issues. I have therefore decided to limit the inquiry of this article to employment-related child-care expenditures.

5. See infra notes $227-36,250-56$ and accompanying text discussing, within the context of employmentrelated child-care expenditures, the business/personal distinction and its relationship to the tax concept of imputed income.

6. See, e.g., Boris I. Bittker, Federal Income Taxation and the Family, 27 STAN. L. REV. 1389, 1445-47 (1975); Lawrence Zelenak, Children and the Income Tax, 49 TAX L. REV. 349, 359-61 (1994).

7. See, e.g. ABA Section on Taxation, Report of the Child Care Credit Task Force, 46 TAX NOTES 331, 334-35 (1990).

8. See infra notes 271-374 and accompanying text (describing the analysis of employment-related childcare expenditures found in influential tax law texts and showing that the waged child-care worker played no role in that analysis).

9. See Anne L. Alstott, Tax Policy and Feminism: Competing Goals and Institutional Choices, 96 COLUM. L. REv. 2001, 2056-59 (1996). Further evidence of the invisibility of child-care workers in Professor Alstott's analysis is the definition she adopts for the term "caregivers." She defines them as "women or men who perform family labor" using the term "family labor" to mean "the unpaid work of caring for children and other family members." Id. at $2004 \mathrm{nn} .11$ \& 13.

10. See, e.g., id. at 2025-26 
which is based on the proposition that economic exploitation, sexism, and racism operate together, holds out the promise of uncovering this type of analytical shortcoming and thereby enhancing our understanding of the economic implications of a tax rule. ${ }^{11}$

Part I briefly describes the tax treatment of employment-related child-care expenditures for the benefit of those readers who are unfamiliar with the current law. Parts II through IV adopt the critical methodology developed by critical race theorists and legal feminists that stresses historical contextualization in the reading of legal texts. The purpose of Part II is to establish the historical context for evaluating the development of the tax provisions as well as the tax policy discussions surrounding those provisions. The analysis found in this Part is designed to reveal the class, gender, and race subordination in the social and economic arrangements involving childcare found in different parts of the country at different times during the nineteenth and twentieth century. Section A studies the role domestic work in general and childcare in particular played in the United States from the nineteenth century until World War II. Section B builds on the historical analysis found in Section A and discusses post-war trends in the labor market, some post-war legislative efforts dealing with childcare, and the current demand for and the nature of child-care services. The conclusion drawn from the historical study of childcare is that child-care services shape contemporary understandings of class, gender, and race and that class, gender, and race shape contemporary understandings of child-care services.

11. An equally important reason for studying the tax treatment of child-care expenditures is that sections 21 and 129 historically have represented the largest source of federal financial support for child care. See Reclaiming the Tax Code for American Families: Hearings Before the House Select Comm. on Children, Youth, and Families, 102d Cong., 1st Sess. 89 (1991) (statement of Nancy Duff Campbell, Managing Attorney, National Women's Law Center, Washington D.C.) [hereinafter Campbell Statement]. See also ABA Section on Taxation, supra note 7, at 333 ("Of the more than 20 separate federal programs providing child care assistance, the child and dependent care credit is the largest, providing some 60 percent of all Federal spending for child care."). The significance of the tax credit resulted from a decrease in government spending for direct subsidies and a liberalization of the tax credit and an increased use of it by eligible families. See Philip K. Robins, Economic Implications of Dependent Care Alternatives, 46 TAX NOTES 343, 349-50 (1990). Estimates are that from 1976 to 1988, the amount of governmental support for child care provided through the tax credit increased by $412 \%$ in constant dollars. See id. at 351 . This increase is attributable most to the increased use of it by eligible families. "It is estimated that the percentage of families with working mothers using the credit increased from 18.2 percent in 1976 to 44.3 percent in 1985 . In contrast, the average constant dollar credit per family increased by only about Il percent from 1976 to 1986." Id. Budget estimates for 1997 were that the cost of section 21 to the federal government will be $\$ 2.8$ billion. See JOINT COMM. ON TAXATON, 103D CONG., ESTIMATES OF FEDERAL TAX EXPENDITURES FOR FISCAL YEARS 1994-1998 PREPARED FOR THE COMMTTIEE ON WAYS AND MEANS AND COMMTTEE ON FINANCE, table 1 (Comm. Print 1995). The figure used is a combination of the cost of the credit for child care as well as adult dependent care. Most analysts agree that the credit is used overwhelmingly for child-care expenditures. See Campbell Statement, supra, at $89 \mathrm{n}$.3. The cost of section 129 was estimated to be $\$ .8$ billion. See JOINT COMM. ON TAXATION, supra, at tbl. 1. Regardless of recent government efforts to fund child care directly, see infra notes 386-89 (describing the 1996 welfare reform legislation that includes federal money for child care), with $\$ 3.6$ billion at stake having to do with the well being of our children and the persons charged with their care, the tax treatment of child-care expenditures is worthy of serious consideration. A complete picture of government supported child care requires consideration of state policies. See Sharon C. Nantell, The Tax Paradigm of Child Care: Shifting Attitudes Towand a Private/ParentalPublic Alliance, 80 MARQ. L. REV. 883, 919-37 (1997) (describing a wide range of state tax provisions relating to child care). 
The historical analysis in Part II showing that child-care services are not distinct from, but are part of, a social and economic system of class, gender, and race subordination becomes the foundation for incorporating the antisubordination principle into a comprehensive tax analysis of child-care expenditures. Part III relies on a traditional tax policy framework to analyze child-care expenditures, describing and applying the widely accepted ideal income tax base developed by Robert Haig and refined by Henry Simons. ${ }^{12}$ The business/personal distinction and imputed income, which are key analytical components of the ideal tax base, are the central focus of the discussion. This Part shows that conventional tax approaches provide little guidance about the appropriate tax treatment of child-care expenditures. This Part further demonstrates how the history of child-care services reveals that the seemingly objective analytical tools of the business/personal distinction and imputed income are limited in their usefulness because they are rooted in the very ideas and practices that have produced systematic subordination based on class, gender, and race.

Part IV continues to interpose the antisubordination principle into traditional tax analysis by examining the three most influential tax law texts dealing with child-care expenditures. The first text analyzed is Henry Simons's pathbreaking book Personal Income Taxation, ${ }^{13}$ the second is the opinion of Judge Opper in the case of Smith $v$. Commissioner, ${ }^{14}$ and the last is Stanley Surrey's book Pathways to Tax Reform: The Concept of Tax Expenditures. ${ }^{15}$ The textual analysis demonstrates that the three authors are unpersuasive when they rely on tax principles to support their conclusions that child-care expenditures should not be excluded from the tax base. Through a close reading of the texts and reference to the historical material presented in Part II, Part IV shows how each author relies on accepted roles based on class, gender, and, in a less obvious way, race to create the appearance of applying tax rules objectively. Subjecting these texts to an antisubordination analysis and uncovering their logical missteps has the important effect of disrupting their influential power. Once the traditional deference to these texts and the tax principles upon which they rely is shown to be unjustified, room is made for deciding the question of the appropriate tax treatment of child-care expenditures by adopting a broader analytical framework.

Part V is an attempt to build an alternative framework that integrates traditional tax and antisubordination principles. Based on the historical examination of child-care services, it demonstrates the class, gender, and race implications of the current tax law regarding child-care expenditures and proceeds to consider alternative approaches. What is most important about the

12. See infra notes 228-29 and accompanying text (discussing the development of the ideal income tax base).

13. Henry C. Smons, Personal income taxation: The definttion of income as a Problem of FISCAL POLICY (1938).

14. 40 B.T.A. 1038 (1939), aff'd per curiam, 113 F.2d 114 (2d Cir. 1939)

15. Stanley SurReY, Pathways to TaX REForm: THE CONCEPT of TAX EXPENDITURES (1973). 
analysis found in Part V is that it shows how the antisubordination principle enhances understanding of the social and economic implications of a tax rule, and how it is essential to the tax law in achieving its goals of equity, administrability, and economic rationality. The Conclusion suggests further avenues of inquiry arising out of the introduction of the antisubordination principle into the tax law.

\section{CURRENT TAX TREATMENT OF EMPLOYMENT-RELATED CHILD-CARE EXPENDITURES}

This section briefly explains the current tax treatment of child-care expenditures and its limited usefulness, especially to low-income taxpayers. As the description of the tax provisions below make clear, Congress has limited the availability of tax relief to those taxpayers who incur child-care expenditures for employment-related purposes. Some of the legislative history of section 21 from its inception in 1954 is discussed in Part IIB ${ }^{16}$ A further critique of both sections 21 and 129 is found in Part V. ${ }^{17}$

Section 21 provides a nonrefundable credit equal to between twenty and thirty percent of the expenditures incurred for childcare during the taxable year that enable the taxpayer to be gainfully employed. ${ }^{18}$ The percentage of expenditures allowed varies depending on the taxpayer's adjusted gross income. ${ }^{19}$ The amount of the employment-related child-care expenditures that may be taken into account to determine the amount of the credit is limited. If a taxpayer has one child in childcare, no more than $\$ 2,400$ can be used to determine the credit, and if the taxpayer has two or more children, no more than $\$ 4,800$ can be used to compute the amount of the credit. ${ }^{20}$ Section 129 authorizes an employer provided assistance program for childcare. An employee is allowed to exclude from gross income up to $\$ 5,000$ ( $\$ 2,500$ in case of a married person filing a separate return) of child-care expenditures that are either paid, reimbursed, or provided in kind by the employer. ${ }^{21}$ Section 125 permits an employer-provided

16. See infra notes $157-69,257-60$ and accompanying text (describing section 21 's legislative history).

17. See infra Part $V$ and accompanying text (critiquing sections 21 and 129 as part of an analysis of alternative tax approaches to employment-related child-care expenditures).

18. See I.R.C. § $21(\mathrm{a})(1)$. The income exclusion allowed under section 129 would seem to undermine the structure of the child-care credit under section 21 , which is designed to limit the tax benefits of high-income taxpayers. Section 129, however, might be more advantageous to low-income taxpayers than the credit. See Edward J. McCaffery, Taxation and the Family: A Fresh Look at Behavioral Gender Biases in the Code, 40 UCLA L. REV. 983, $1018 \mathrm{n} .135$ (1993) (showing how the operation of the earned income credit could lead to an effective marginal rate for a married couple of $27.4 \%$, thereby making the exclusion under section 129 more advantageous in some instances than the credit under section 21). The problem is apparently that the mechanisms for lower-income taxpayers to take advantage of this benefit have proven so cumbersome that section 129 continues to benefit higher-income taxpayers the most. See id.

19. See I.R.C. $\$ 21(\mathrm{a})(2)$ (the $30 \%$ maximum percentage is reduced by 1 percentage point for each $\$ 2,000$ (or fraction thereof) by which the taxpayer's adjusted gross income exceeds $\$ 10,000$, but the percentage is never less than $20 \%$ )

20. See I.R.C. $\S 21$ (c).

21. See I.R.C. $\S 129$. To qualify for the income exclusion a number of different requirements must be 
child-assistance program to be part of a cafeteria plan. ${ }^{22}$ An employee can exclude from income reimbursements for child-care expenditures up to $\$ 5,000$, as authorized by section $129 .^{23}$

One significant practical limitation of both sections 21 and 129 is that the child-care expenditures taken into account are less than the costs incurred by the taxpayers. ${ }^{24}$ Section 129 is further problematic because it is available only if an employer establishes the program. ${ }^{25}$ A significant decrease in the use of the credit occurred in 1989 after the passage of the Family Support Act of 1988, which required that taxpayers claiming the credit include the provider's name, address, and taxpayer identification number. ${ }^{26}$ One explanation might be that some taxpayers were claiming expenditures that they were in fact not paying. A more likely explanation is that child-care workers who do not report their income did not give their employers their taxpayer identification numbers. ${ }^{27}$ Apparently, at least for some taxpayers in need of childcare, the value of the child-care credit and the potential penalties for failure to comply with the law are less than the savings obtainable by using the underground economy. Those savings include avoiding payment of at least the employer's share, if not also the employee's share, of social security taxes as well as avoiding payment of a high enough salary to permit the child-care worker to net a living wage. ${ }^{28}$ Not everyone made

met. The requirements under sections 21 and 129 are quite similar. For example, both require that the taxpayer provide the "name, address, and taxpayer identification number" of the provider on the return. $\S \S 21(\mathrm{e})(9)$, 129(e)(9). Section 129 contains some other qualifications related to the fact that it concerns an employerprovided assistance program. For example, to qualify, the plan must meet a number of different nondiscrimination requirements to assure that it is available generally to the employer's work force. See $\S$ 129 (d). In addition, the two provisions are coordinated. For example, the dollar limit on expenses under section 21 must be reduced by the amount excluded from gross income under section 129 . See $\S 21$ (c).

22. See I.R. C. § 125(a), (e)(1).

23. Not only is the amount excluded under sections 125 and 129 from gross income for federal income tax purposes, it is also excluded from state income taxes and social security taxes. See I.R.C. $\$ 3121$ (a)(18). The exclusion from social security taxes means, however, that some employees may, depending on their income level, receive lower social security benefits than they otherwise would have. In addition to the exclusions under sections 125 and 129 having implications for the employee under the social security system, they also may lead to a reduction in pension coverage. See I.R.C. § 414(s); Treas. Reg. § 1.414(s)-l(a)(2) (as amended in 1993) (a plan must exclude amounts provided under section 129 as compensation for purposes of complying with nondiscrimination provisions applicable to pensions and may exclude amounts provided under section 125 for this purpose, but it is not required to use this same definition of compensation for purposes of calculating the amount of contributions or benefits actually provided under the plan).

24. The amount that is excludable is even more inadequate for those employees with more than one child. The amount is the same regardless of the number of children a taxpayer may have. See I.R.C. $\S 129$ (a). For a taxpayer with one child, however, the exclusion under section 129 may be significantly more advantageous than the credit under section 21 , which limits the expenditures subject to the credit for one child to $\$ 2,400$. See I.R.C. $\$ 21$ (c)(1).

25. See Dependent Care Assistance Programs Provided by 68 Percent of Employers Surveyed, 66 TAX NOTES 324, 324 (1995) (reporting that $68 \%$ of the employers surveyed provided dependent care assistance programs and nearly all of them (97\%) offered it through a dependent care flexible spending account; also reporting that $34 \%$ of the employers indicated that the savings on Social Security and unemployment taxes frequently or always outweighed the administrative costs of the programs). For further discussion of the relationship of social security to the income tax exclusion for child-care expenditures, see supra note 23.

26. See I.R.C. $\S 21(\mathrm{e})(9)$.

27. See Campbell Statement, supra note 11 , at 93.

28. The cost of Social Security taxes are significant and cannot be ignored in discussing the child-care labor market. Cf. McCaffery, supra note 18, at $997-98$ (demonstrating how "social security contributions pose 
this decision. The number of returns reporting income from child-care services increased sixty-five percent from 1988 to 1989 , which is the year the requirement of providing a taxpayer identification number was added to section $21 .{ }^{29}$

A second aspect of the child-care credit that reduces its usefulness to lowincome taxpayers involves structural changes made by the Tax Reform Act of 1986 (TRA) and the recently enacted child credit provided under section $24 .^{30}$ The child-care credit neither provides for an inflation adjustment of the income limitations determining the applicable percentage of expenses, nor for the expense limitations. Moreover the child-care credit is not refundable. After the TRA, which indexes the standard deduction, the dependency exemptions, and the tax brackets, the maximum child-care credit of thirty percent available to taxpayers with incomes of $\$ 10,000$ is illusory because persons with income at this level do not owe taxes. ${ }^{31}$ IRS data demonstrate that the number of taxpayers with adjusted gross incomes under $\$ 15,000$ claiming the child-care credit has decreased every year since $1986 .{ }^{32}$ Fewer public complaints have been registered with regard to the child-care assistance program's limitation of $\$ 5,000$ even though it is also not indexed. The attention paid to the child-care credit, but not to the child-care assistance program, is probably attributable to the fact that most of those taxpayers benefiting from a child-care assistance program are at higher income levels and are still enjoying some benefit from the income exclusion. The recently enacted child credit further reduces the usefulness of the child-care credit for low-income taxpayers. The limitations placed on the child-care credit and the child credit result in tax reductions or in refunds for low-income working families with employment-related child-care expenditures that are not substantially more than they would have been had the child-care expenditures not been incurred. ${ }^{33}$

The nature of the limitations imposed by sections 21 and 129 should be kept in mind in considering the history of waged childcare found in Part II and the critique of traditional tax analysis found in Parts III and IV. As we will see, our understanding of the current tax treatment of child-care expenditures changes dramatically upon the introduction of the antisubordination principle into the tax

a higher burden for all but the wealthiest Americans"); see also David Cay Johnston, Taxes on Nannies Are Going Unpaid Despite New Law, N.Y. TIMES, Apr. 5, 1998, at 1 (reporting a reduction in the number of taxpayers paying the employer's share of social security, medicare and federal unemployment taxes for childcare providers and housecleaners whom they hire).

29. See Campbell Statement, supra note 11, at 93

30. See id. at 90-93; Zelenak, supra note 6, at 413 n.321; Mary L. Heen, Child Care, Welfare Reform, and Taxes, 2 COMMUNITY TAX L. REP., Oct. 1997, at 1, 15-17; see also EDWARD J. MCCAFFERY, TAXING WOMEN 115-18 (1997) (showing that in all income ranges, the child-care credit is relatively rarely used and among lower-income households it is virtually not claimed); Martin J. McMahon Jr., The New Child Credits: Explainable Mechanics and Unfathomable Policy, 76 TAX NOTES 1625 (1997) (discussing the computation of the child credit and its relation to the earned income tax credit).

31. See I.R.C. $\$ \S 1(f), 63(c)(4), 151$ (d)(3).

32. See Campbell Statement, supra note 11, at 91

33. See Heen, supra note 30, at 15-17. 
analysis. One of the key reasons our understanding changes is that the antisubordination principle encourages us to focus on the relationship between the consumer and the waged provider of childcare.

\section{THE HISTORY OF WAGED CHILDCARE}

Childcare is part of a whole range of activities, such as housecleaning, food preparation and service, and laundering and repairing of clothing, frequently referred to as reproductive labor.$^{34} \mathrm{~A}$ history of waged childcare must therefore be placed within the broader history of waged domestic work. A review of waged childcare in the United States shows that the wages and working conditions for child-care workers have not been, and are not currently, the product of a free competitive market establishing an equilibrium between supply and demand. The labor history instead shows how social prejudices and government intervention have produced those wages and working conditions. With an understanding of that market, a tax analysis that looks at the purchasing of child-care services as an objective fact unrelated to the political and economic strongholds of power that influence the nature of that transaction becomes inadequate. A comprehensive tax analysis that applies the antisubordination principle would necessarily take into account the economic exploitation, racism, and sexism that occurs in the child-care labor market. ${ }^{35}$

A substantial amount of the historical data that follows relates to domestic work in general, rather than child-care work specifically. I rely on it because it is often difficult to segregate one aspect of reproductive labor from another. I also rely on it because it provides an important context for evaluating practices found in the child-care labor market, discreetly considered. Although considering childcare within the broader context of domestic work is useful, it cannot be

34. See, e.g., Shellee Colen, "Like a Mother to Them": Stratified Reproduction and West Indian Childcare Workers and Employers in New York, in CONCEIVING THE NEW WORLD ORDER: THE GLOBAL POLITICS OF REPRODUCTION 78, 78 (Faye D. Ginsburg \& Rayna Rapp eds., 1995); Evelyn Nakano Glenn, From Servitude to Service Work: Historical Continuities in the Racial Division of Paid Reproductive Labor, 18 SIGNS I, l (1992)

35. The conclusion that child-care arrangements are the product of class, gender, and race subordination is well supported in the literature from other disciplines, such as social history, economics, and sociology. This literature demonstrates that reproductive labor is a system that establishes and is itself established by hierarchical relationships. As Shellee Colen writes, "physical and social reproductive tasks are accomplished differentially according to inequalities that are based on hierarchies of class, race, ethnicity, gender, place in a global economy, and migration status and that are structured by social, economic, and political forces." Colen, supra note 34, at 78. Colen and Roger Sanjek underscore the important role domestic work plays in constructing (reproducing) hierarchies when they write

In a broad sense, household work does more than provide reproductive labor for employer households and wages for workers. ... [I]t also reproduces the relations of inequality in its local society, the very relations that structure recruitment of workers. These relations of inequality include gender, age, ethnicity, race, class, and migration status, and most often compound two or more of these axes of differentiation.

Shellee Colen \& Roger Sanjek, At Work in Homes I: Orientations, in AT WORK IN HOMES: HOUSEHOLD WORKERS IN WORLD PERSPECTIVE 1, 5 (Roger Sanjek \& Shellee Colen eds., 1990) (footnote omitted) (citation omitted). 
done without paying attention to the historical data which indicates that, within domestic work, employers frequently favored white native-born or immigrant women to do child-care work. ${ }^{36}$ As child-care workers, the women frequently enjoyed higher status, and concomitantly better working conditions, than many women who were performing other forms of reproductive labor, such as laundry, cooking, or housecleaning. ${ }^{37}$ As the discussion that follows shows, the higher status of the work depended on it being performed by white women, and it was performed by white women because the work did have higher status.

\section{A. Domestic Work from the Nineteenth Century Until World War II}

\section{The Respectability/Degeneracy Distinction}

Domestic work has existed, in the form of slavery, indentured labor, and free labor throughout the history of the United States. ${ }^{38}$ In the late 1700 s and early 1800 s, the patterns of domestic work diverged between the North and the South. Black African enslaved labor became prevalent in the South while nonimmigrant free laborers predominantly performed domestic work in the North. ${ }^{39}$ The "intertwined" systems of slavery and service, albeit to differing degrees,

36. See MARY ROMERO, MAD IN THE U.S.A. 80-81 (1992).

37. See Colen \& Sanjek, supra note 35, at 5, 13 n. 11 (observing that child-care work as contrasted with housecleaning "seems to carry less stigma in contemporary North America than other tasks"); infra note 64 (discussing the contradictions surrounding the role of the Victorian governess).

38. See ROMERO, supra note 36, at 51; Glenn, supra note 34, at 4. Transported convicts and indentured white domestic workers were found in all the colonies, but especially in the middle and southem ones. See JUDTH ROLLINS, BETWEEN WOMEN: DOMESTICS AND THEIR EMPLOYERS 49 (1985). Indians performed domestic work mostly in New England and Black Africans performed domestic work mostly in the South. See $i d$. Judith Rollins reports that " $[\mathrm{t}]$ hough servants of European descent had slightly more legal protection, . . . all categories of servants were treated poorly; work conditions . . . were often wretched and physical brutality commonplace." Id. She goes on to observe that the colonialists reconciled their democratic ideals of egalitarianism with their treatment of domestic workers by constructing them to be "of classes and/or races considered biologically inferior; liberal democratic principles simply did not apply to them." Id.

39. See Rollins, supra note 38 , at 50 . Rollins suggests that democratic ideas influenced greatly the relationship between the employer and the domestic worker in the Northeast. She reports that the term help supplanted the term servant and liveries became rare as the relationship was no longer marked by servility or subservience on the part of the domestic laborer. See id. Other familiar terms included hired man, hired hand, and hired girl. See DAVID R. ROEDIGER, THE WAGES OF WHITENESS: RACE AND THE MAKING OF THE AMERICAN WORKING CLASS 50 (1991). Notably, this form of servitude emerges in the Northeast when the employee performing domestic work is of the same community, ethnicity, and religion of the employer. See RoLLINS, supra, at 50. Although David Roediger agrees that this developing language of labor was evidence of republicanism and egalitarianism, he persuasively argues that the new words were inseparable from the workers', as well as the employers', interests in distinguishing the relationship from that of slave and master.

[I]n a society in which Blackness and servility were so thoroughly intertwined-North and Southassertions of white freedom could not be raceless. To criticize Europe as 'slavish' or full of 'dastardly slaves' inevitably called to mind chattel slavery . . . .

The existence of slavery (and increasingly of open Northern campaigns to degrade free Blacks) gave working Americans both a wretched touchstone against which to measure their fears of unfreedom and a friendly reminder that they were by comparison not so badly off. It encouraged an early language of labor that was at once suffused with concern for 'republican liberty' and at the same time willing to settle for .. . 'evasions.'

ROEDIGER, supra, at 49-50 
touched most towns and homes in the United States. ${ }^{40}$

In the middle of the nineteenth century, it seems fair to say that domestic work was a site where class and racial prejudices were established as well as reflected. The most notable change that occurred during the second half of the nineteenth century was that the nation attained the highest proportion of female wage earners in domestic service than at any other time in its history. ${ }^{41}$ This burgeoning of the ranks of domestic workers is traditionally attributed to the expansion of the middle class who, through manufacturing, clerical, and sales positions, acquired the means to hire domestic workers. ${ }^{42}$ Although there is significant evidence to support a marketplace-demand explanation, it fails to capture the interrelationship of events by overemphasizing only one aspect of the industrial revolution. In a world of economic growth and expansion, we need to explain why so many in the middle class chose to consume their discretionary income by hiring domestic workers rather than taking advantage of an array of investment opportunities that held the potential of providing them with more economic security and wealth. It is only with an elaboration of the effects of other economic, political, and social changes, such as the liberation of enslaved women and men in the South, the conquering of Mexican lands in the Southwest, inter- and intranational migration, European colonization efforts, and women's suffrage and reform movements, that the complex forces affecting the middle-class home and domestic work are revealed.

Social historians have shown that early in the nineteenth century, within the context of an emerging urban capitalism and the growing influence of Evangelical Christian religion in both England and the United States, respectability became closely associated with the work ethic, good character, independence from patronage, sobriety, chastity, and dedication to family. ${ }^{43}$ The achievement of these attributes is what set apart the middle class from the aristocracy, the working class, and others who without these attributes could be categorized as degenerate. ${ }^{44}$ Acquiring respectability became a justification for

40. The consequence of that intertwining is that claims by nineteenth-century workers performing domestic work to free labor and dignity were racial claims to whiteness.

41. See Evelyn Nakano GlenN, Issei, Nisei, War Bride: Three Generations of Japanese AMERICAN WOMEN IN DOMESTIC SERVICE 100 (1986); see also THOMAS DUBLIN, TRANSFORMING WOMEN'S WORK: NEW ENGLAND LIVES IN THE INDUSTRIAL REVOLUTION 157-58 (1994) ("In 1870 . . Boston had one servant for every three and one-half families in the city; for New York City and Philadelphia, the comparable proportions were one servant for every four and five families, respectively." (footnote omitted)).

42. See ROMERO, supra note 36 , at 50 .

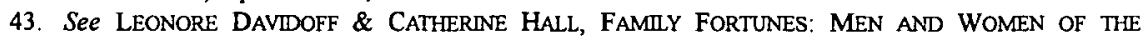
ENGLISH MIDDLE Class, 1780-1850, 108-13, 180-92 (1987); E. ANTHONY ROTUNDO, AMERICAN MANHOOD: TRANSFORMATIONS IN MASCULINTTY FROM THE REVOLUTION TO THE MODERN ERA 20 (1993); Gail Bederman, "Civilization," the Decline of Middle-Class Manliness, and Ida B. Wells's Antilynching Campaign (1892-94), 52 RADICAL HIST. REV. 5, 6 (1992).

44. George Mosse elaborates on how the intellectual construct of middle-class respectability, the term that described the ordered, self-regulating state of bourgeois homes and bodies, came to distinguish bourgeois life:

Through respectability, they [the middle class] sought to maintain their status and self-respect against both the lower classes and the aristocracy. They perceived their way of life, based as it was upon frugality, devotion to duty, and restraint of the passions, as superior to that of the "lazy" lower 
the power that the middle class wielded in economic, social, and political matters. In other words, respectability and its converse, degeneracy, were part of the nineteenth-century ideological language expressing relations of domination and subordination along class, gender, and racial lines. Respectability became an assertion of membership in the middle class and the basis on which one had the right to dominate those classified as degenerate. A primary site where respectability could be produced, as well as displayed, was in the home, and domestic workers had a role to play in that production and display. It is for that reason that respectability becomes a useful lens to use in an inquiry into the history of childcare in the United States.

As we will see, the historical data challenge the myth that marketplace arrangements reflect objective value. Instead, the data link respectability with class, gender, and racial hierarchies and reveal the marketplace as encompassing the ideological constructs and practices that produce, as well as sustain, those hierarchies. Losing the illusion of objective value through historical contextualization of economic arrangements is a necessary first step to appreciating the value of an antisubordination principle in tax policy discussions.

\section{The Cult of Respectability in the Last Half of the Nineteenth Century}

The rise in the percentage of all women laborers hired as domestic workers coincides with the development in the second half of the nineteenth century of an intensification of distinctions, within intellectual thought and through material practices, between women and men, private and public, and home and workplace. The marketplace became characterized as harsh, crude, and brutish while the home became characterized as clean, orderly, and a haven for social and moral graces. ${ }^{45}$ The separate spheres made it possible for a man to earn

classes and the profligate aristocracy.

GEORGE L. MOSSE, NATIONALISM AND SEXUALTTY: RESPECTABILITY AND ABNORMAL SEXUALTTY IN MODERN EUROPE 5 (1985). Mosse continues that once national survival begins to be defined in terms of physical and moral health, and manliness comes to describe those who can possess these qualities, the concept of degeneration emerges as its antithesis. Degeneracy, for Benedict Augustin Morel, who first formulated the concept in medical terms in 1857, is a process of destruction that is brought on by moral and physical poison. See id. at 34-35. Mosse writes:

This deviance from the norm, as Morel called it, could be brought about by such poisons as alcoholism and the use of opium, by debilitating diseases like malaria, but also by the social environment, a nervous temperament, diseased moral faculties, or inherited bodily and mental weakness. Several of these poisons usually combined in order to begin the relentless process of degeneration.

Id. at 35 (note omitted). For further discussion of the different views of degeneracy within sexology in the late nineteenth century, see LAWRENCE BIRKEN, CONSUMTNG DESIRE: SEXUAL SCIENCE AND THE EMERGENCE OF A CULTURE OF ABUNDANCE, 1871-1914, 65-67 (1988). As Birken situates sexology within "the larger history of Western thought," id. at 15 , he shows how the concept of degeneration reflected class, gender, and race differentiations at the tum of the century, see id. at 72-91, as part of his larger argument that sexology "simultaneously furthered and resisted the extension of the concept of citizenship." Id. at 76.

45. See Paula Giddngs, When and Where I ENTER: THE IMPact of Black WOMEN on Race and SEX IN AMERICA 47-49 (1984); ROTUNDO, supra note 43, at 254. 
respect through self-control and good character by looking to his home, wife, and children, leaving him free to lust for power and wealth in the marketplace. Not coincidentally, the barbaric marketplace became a justification for virtuous women to remain in the home and not to compete with men by entering into the public arenas of the workplace, education, or politics. ${ }^{46}$ This era is frequently referred to as either the cult of the lady or the cult of domesticity. ${ }^{47}$

The boundary between the home and the market has been understood as separating the less-valued reproductive labor from the highly-valued industrial progress, but on closer examination, through the lens of respectability, it can be understood as sustaining class and race, as well as the more obvious gender, hierarchies. ${ }^{48}$ It is in the liminal space occupied by domestic work-waged workers doing reproductive labor in the homes of the middle class-that many of these concealed interconnections are unmasked. ${ }^{49}$ To underscore this point and to avoid confusion with earlier writings concerning the cult of the lady or the cult of domesticity, I will refer to the era as the cult of respectability.

Homemaking in the era of the cult of respectability became highly labor intensive as standards increased for cleanliness, orderliness, and ornateness of children, material possessions, and rooms. ${ }^{50}$ Concerns for cleanliness surely were

46. See ROTUNDO, supra note 43 , at 254 ; see also ROMERO, supra note 36 , at $52-53$ (emphasizing how the separate spheres ideology accentuated the dependence of a wife's social position on her husband's and how that social position in turn determined differences in the structure of women's homemaking activity).

47. See, e.g., GDDINGS, supra note 45, at 47-49; Gerda Lerner, The Lady and the Mill Girl: Changes in the Status of Women in the Age of Jackson, 1800-1840, in A HERTAGE OF HER OWN: TOWARD A NEW SOCIAL HISTORY OF AMERICAN WOMEN 182 (Nancy Cott \& Elizabeth Pleck eds., 1979); ROMERO, supra note 36, at 53-58; Barbara Welter, The Cult of True Womanhood: 1820-1960, 18 AM. Q. 151 (1966). As Diane Roberts forcefully demonstrates regarding the distinctions between the meaning of cult of the lady in the North and in the South, it is a mistake to use the concept of the cult of the lady as if it were monolithic in either its practices or effect. See DIANE RoBERTS, THE MYTH OF AUNT JEMIMA: REPRESENTATIONS OF RACE AND REGION 107-09 (1994).

48. Anne McClintock intriguingly connects the inferiorization of domestic workers to colonialism and the idea of "anachronistic space."

Women who transgressed the Victorian boundary between private and public, labor and leisure, paid work and unpaid work became increasingly stigmatized as specimens of racial regression. Such women, it was contended, did not inhabit history proper but were the prototypes of anachronist humans: childlike, irrational, regressive and atavistic, existing in permanently anterior time within modemity. Female domestic servants were frequently depicted in the iconography of degeneration as "plagues," "black races," "slaves" and "primitives."

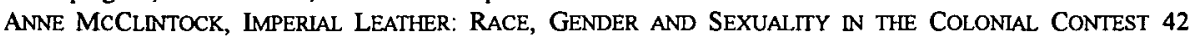
(1995).

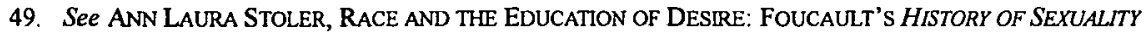
AND THE COLONIAL ORDER OF THINGS 146-47 (1995) ("[T]echnologies . . . designed to affirm the bourgeois self" entailed "discourses [that] were constructed around a spectrum of stereotypic Others, epitomized in the servant class against which the boundaries of the bourgeois self were drawn."); see generally Dorothy $\mathrm{E}$. Roberts, Spiritual and Menial Housework, 9 YALE J. L. \& FEMINISM 51 (1997) (explaining how class, gender, and race hierarchies are reinforced by the distinction between menial and spiritual housework-a distinction that depended on who was performing the tasks).

50. See Suellen Hoy, Chasing Dirt: The American Pursutt of Cleanliness (1995).

Mistresses concentrated on housework for comfort and appearance's sake; and before long "cleanliness, tidiness and the care and arrangement of possessions replaced domestic production as housewives' preoccupations." The upper-middle-class home of the $1840 \mathrm{~s}$ and $1850 \mathrm{~s}$ required downstairs a kitchen and a "wash house" behind it, and upstairs a bath as well as bedrooms and a nursery. 
justified both in the private and public spheres in public health terms, but within the respectability/degeneracy distinction it took on moral and exclusionary overtones. ${ }^{51}$ Suellen Hoy argues that cleanliness "became a route to citizenship, to becoming American" and during the last half of the nineteenth century grew to be "'one of the characteristics of high civilization," which in turn linked cleanliness to whiteness. ${ }^{52}$ As Hoy notes, "[a]t least a century earlier they [Americans], like their English relatives, had often associated the color black with dirt." ${ }^{\text {.53 }}$ Any group perceived as having darker skins than northern Europeans, especially African Americans, Jews, southerm Italians, and Irish were characterized as "filth" who threatened the character and strength of the nation. ${ }^{54}$ The concept of cleanliness, therefore, became one of the technologies used in the nineteenth century to establish the superiority of the middle classes and the inferiority of the lower classes on the basis of race.

The high standards for cleanliness created considerable stress for the middleclass woman, because to be a respectable woman meant she had to be above the dirty work of scrubbing floors and changing babies. The cleanliness/dirt dilemma was resolved for the lady of the house when she transformed homemaking and child-rearing into a profession in which she supervised the reproductive labor of others. ${ }^{55}$ In fact, it was only if she had a domestic worker in the household that she and her husband could know that they had attained respectability. ${ }^{56}$

\footnotetext{
Id. at 18 (footnotes omitted)

51. See id. at 87 .

52. Id. at $87-88$ (quoting from a number of turn-of-the-century publications).

53. Id. at 92

54. See id.

55. See ROMERO, supra note 36, at 53 ("A house kept to the end of display is impossible to all but a few women, and their success is dearly bought.") (quoting RALPH WALDO EMERSON, 7 DOMESTC LIFE: EMERSON'S COMPLETE WORKS 108f (Boston, Houghton Mifflin 1893)). Phyllis Palmer elaborates further on the relationship of the lady of the house to the domestic worker.

$[\mathrm{H}]$ ousewives felt so put upon by endless unpaid work that they wanted desperately to extricate themselves. Thus it was in their interest to pay low wages for such labor; they had an incentive to perpetuate the low social esteem and presumed low economic value of housework. . . Caught in the conflict between society's denigration of housework and evaluation of women on its competent conduct, housewives did not challenge the middle-class norm of housework; rather, they projected their dilemma onto the women less powerful than themselves whom they employed
}

Phyllis Palmer, Housewife and Household Worker: Employer-Employee Relationships in the Home, 19281941, in "TO TOL THE LIVELONG DAY": AMERICA'S WOMEN AT WORK, 1780-1980, 179, 191 (Carol Groneman \& Mary Beth Norton eds., 1987) [hereinafter To TOL THE LIVELONG DAY]; see also HoY, supra note 50, at 19 (arguing that the practice of hiring domestic workers "kept the sexual division of labor intact"); MCCLINTOCK, supra note 48, at $97-98$ (detailing how the "emblems of upper-class prestige depended on the deadly labor of the female working class" by describing the labor of the seamstresses who produced the "sumptuous dresses of London's idle upper-class women," but not further acknowledging the deadly labor performed in the colonies to produce the cotton cloth that became the "sumptuous dresses"); Glenn, supra note 34, at 7 (observing that white middle- and upper-class women hired other women to do the hard and distasteful tasks required in the household rather than challenging the gender-based division of reproductive labor).

56. See Glenn, supra note 34, at 6-7; see also DEBORAH VALENZE, THE FIRST INDUSTRIAL WOMAN $157-$ 58 (1995) (analyzing domestic work in the late eighteenth and nineteenth centuries in England by describing a trend of wealthier wives of tradesmen and farmers expressing a "distaste for the hard labor of housewifery," made more burdensome by rising standards of housekeeping, and finding the solution in the hiring of domestic workers and concluding that " $[t]$ hough not every middle-class family employed a servant, many did; added to 
More was at stake in the employer/employee relationship for the lady of the household than a clean and orderly child and home. The supervision specifically was designed to "imprint[] the work with signs of inferiority, deference, and servility," $" 57$ raising the question: How was respectability maintained (how was the middle class served) by degrading the reproductive labor performed by the domestic worker and the worker herself?

The practices of inferiorization not only were designed to convey to the domestic worker her subordinate status relative to the middle-class family and especially to the lady of the household, but they were also designed to provide assurances to the family of their superiority. Those assurances were particularly crucial because the domestic worker embodied, both materially and figuratively, the contradictions of middle-class life. ${ }^{58}$ Not only was the home supposed to be free of commerce, but women were not supposed to be participating in commerce. Yet, here was a woman receiving payment for work performed in the home. The contradiction was even further complicated by the fact that she was getting paid for doing reproductive labor that was supposed to be produced without pay. ${ }^{59}$ The domestic worker entering the home as a waged laborer created an incursion on the security of middle-class life. The domestic worker knew the very truth that middle-class life was designed to eradicate- -she knew its dirtiness. ${ }^{60}$ In order to render her intimate knowledge of middle-class dirt insignificant, she had to be stripped of the ability to know. She had to be stripped

these numbers were lower-class households needing 'another pair of hands in the workshop or at the counter,' making domestic service a widely extended form of employment" that resulted in a hierarchy with "the woman of greater means acting as supervisor over one or more lower-class servants" that allowed her the leisure that was becoming of her "gentility" and domestic workers that were "a measure of her wealth")

The management model found in the public factories frequently was incorporated into the households, which meant that domestic work became unskilled supervised work that was highly regulated, such as washing had to be done on Mondays and silver polishing on Thursdays. See ROMERO, supra note 36, at 57-58, 62 (reporting that "domestics themselves pushed for working conditions resembling the businesslike relationship between worker and boss in the factory or office"); Sedef Arat-Koc, In the Privacy of Our Own Home: Foneign Domestic Workers as the Solution to the Crisis in the Domestic Sphere in Canada, 28 STUD. POL. ECON. 33, 54 (1989) (arguing that feminists like Charlotte Perkins Gilman, Melusina Fay Pierce, and Mary Livermore "prioritize[d] extension of the principles of industrialization over concerns for equality" by disregarding the interests of household workers and seeing their work, deemed wasteful, annoying, and unreliable, as a problem to be solved "through rigid supervision and factory-like discipline").

This level of intense supervision, regulation, and orderliness can be seen both as mimicking industrialization and creating, nurturing, and embodying the very values that commercial expansion needed. Anne McClintock, challenging the separate spheres of home and workplace, describes the common regulatory attributes as the "concealed alliance" between the "cult of industrial rationality and the cult of domesticity." MCCLINTOCK, supra note 48, at 168 .

57. ROMERO, supra note 36 , at 58 .

58. Cf. id. at $\mathbf{5 0}$ (reasoning that, in the context of nineteenth-century England, "the middle classes found it necessary to draw rigid class lines between master and servant" because they "themselves may have been only one generation away from servanthood"); STOLER, supra note 49, at 109-10 (discussing the "micromanagement of domestic life" as a response to domestic workers "who were viewed as subversive contagions in those carefully managed colonial homes" in reference to the Dutch and the Dutch colonies in the nineteenth century).

59. See MCCLINTOCK, supra note 48 , at $164-65$

60. This story was further complicated by the fact that the appearance of leisure was achieved in many homes that could not afford more than one domestic worker by the labors of the "lady," which were all the more laborious because the lady's labors had to be concealed. See id. at 161-62. 
of her subjectivity. By degrading her and her work, the middle-class family transformed her from a knowing subject into an invisible object and in the process made the reality of their dirt a nonreality. ${ }^{61}$ Tax policymakers' failure to consider the child-care worker in their discussions of child-care expenditures takes on a different cast when held up to the light of the late nineteenth-century middle-class home. ${ }^{62}$

The strategy of objectification and invisibility, of course, contained its own contradictions. By constructing the domestic worker as a degraded object, the lady of the household was faced with yet another dilemma. She could only distance herself from degrading dirt by having it removed from her home by a domestic worker, but by letting the domestic worker into her home, she understood herself to be admitting a contamination. ${ }^{63}$ The domestic worker was the degradation that the home was not supposed to contain, but only if the domestic worker was in the home could the home rid itself of degradation.

The contradictions would seem to be most confounding when the domestic work being provided was childcare. ${ }^{64}$ Mothers and fathers seemingly were required to engage in a wide range of strategies to deny the implications of having their children, during their formative years, being nursed, bathed, comforted, and disciplined by the contaminated Other. ${ }^{65}$ To reconcile the caretaking role of the domestic worker with the responsibility of reproducing themselves through their children, the middle-class parents not only had to denigrate the child-care work and the worker, but they had to socialize their children to do the same. Within the context of waged childcare, therefore, we see how middle-class respectability is inextricably linked to working-class women's

61. See VALENZE, supra note 56, at 158 (showing that the hierarchical dimensions associated with the cult of the lady "absolutely depended on the denigration of household tasks"). McClintock further explores the relationship of dirt to class when she writes, "dirt was the memory trace of working class and female labor, unseemly evidence that the fundamental production of industrial and imperial wealth lay in the hands and bodies of the working class, women and the colonized." MCCLINTOCK, supra note 48, at 153-54.

62. See supra notes 9-11 (critiquing Professor Alstott's article for not considering the waged child-care worker in her analysis of the role of feminist legal theory in tax policy); infra notes 271-374 and accompanying text (describing the analysis of employment-related child-care expenditures found in influential law texts and showing that the waged child-care worker played no role in that analysis)

63. See STOLER, supra note 49 , at 112 (identifying similar types of tensions and transgressions in the colonial as well as the Dutch home, in the context of the Netherlands and its colonies).

64. The position of governess, most typically a white, educated, single woman, established, for those who could afford one, yet another level within the stratified system of reproductive labor. This "solution" served to reinforce racial hierarchy while at the same time exacerbating the very contradictions it was supposed to solve. As McClintock observes within the context of a colonial economy, the Victorian governess was

[r]acially a member of the white elite, [but] she was in reality a member of the serving class. . . She

was paid for work, which the housewife did for free. All in all, the white governess embodied some

of the most abiding contradictions of the colonial economy of female labor. MCCLINTOCK, supra note 48 , at 277.

65. Cf. id. at 270-71 (considering this question regarding British middle-class identity and the effect of children being cared for by "black maids and nurses" in the colonies); $i d$. at 82, 94-95 (elaborating on why psychoanalysis needs to reconsider the "body of the working-class woman" and address middle-class men's "unsettling memory of female power and agency, embodied in the memory of the nurse"); Colen, supra note 34 , at 90-91 (discussing West Indian workers' frustration, in the context of the 1980s in New York City, as well as affective ties forged, when they are given "the responsibility for socializing children without . . . the authority to discipline them"). 
degradation. An inevitable byproduct of naturalizing the denigration of domestic work and the creation of the lady of leisure was the disavowal of the economic value of women's reproductive labor. ${ }^{66}$ Within the middle-class formation, reproductive labor became invisible-an invisibility that naturally found its way, as we will see, into traditional tax analysis. ${ }^{67}$

\section{Geographic Variations from the Last Half of the Nineteenth Century Until World War II: Class, Gender, and Racial Stratification}

Although variations of geography and time periods led to different specific household arrangements, pervasive and tenacious gender and racial stratification characterized domestic labor in the United States in the second half of the nineteenth century. ${ }^{68}$ To be a member of the white middle-class required the hiring of domestic workers and to be a domestic worker was to be a non-white woman of the lower classes. ${ }^{69}$ Domestic work became constructed as degrading work because it was performed predominantly by non-white women, and nonwhite women became constructed as inferior because they predominantly did domestic work. $^{70}$

Given the particularized instability created by the domestic worker crossing over, both literally and figuratively, the threshold of the home, it is not surprising that the middle classes, as well as whites from the working classes, easily called upon the racial caste system embodied in the technology of cleanliness to enforce

66. Cf. Arat-Koc, supra note 56, at 37-38 (discussing the domestic sphere and the "physical, economic, and ideological invisibility of domestic labour").

67. See MCCLNTOCK, supra note 48 , at 164.

68. Cf. Arat-Koc, supra note 56, at 44-45 (describing active Canadian state involvement in the recruitment and control of domestic workers in the late nineteenth century, which included making the immigration of household workers easier, as well as sending immigration employees to England and Scotland to recruit and enforcing indenturing arrangements; also explaining how recruitment through the 1920s was closely linked to Canada's nation-building efforts and aided by middle-class women and social reformers, assured that the household workers were of the "'right' national and racial stock and character").

69. See Glenn, supra note 34, at 9-10. When describing domestic work in England, McClintock says that the "widest definition of the middle class . . . was that of keeping domestic servants," MCCLINTOCK, supra note 48, at 85 (quoting ERIC HOBSBAWM, THE AGE OF CAPITAL 286 (1977)), and that "[t]he essence of middleclassness was the experience of relating to other classes or orders of society. With one group, domestic servants, the middle class stood in a very special and intimate relationship: the one fact played an essential part in defining the identity of the other." Id. at 405 n.30 (quoting JOHN FLETCHER CLEWS HARRISON, THE EARLY VICTORIANS, 1832-51, at 110 (1971)).

70. See ROLLINS, supra note 38, at 52; see also GlENN, supra note 41 , at 5 ("For racial-ethnic women concentration in domestic service in turn reinforced their degraded status in society. They came to be seen as particularly suited for, and only suited for, degraded work. Racial-ethnic status and occupational position became more or less synonymous badges of inferiority."). Colen \& Sanjek provide a further explanation of how the nature of waged domestic work permits employers to rationalize the inferiority of the worker:

[T]he time demands of household work frequently constrain workers from maintaining their own households and participating fully in their own intimate family relationships. These circumstances reinforce employer rationalizations of exploitive behavior, and augment the social stigma of household work. When household work comes to characterize a social group, it stigmatizes in a way that other working-class occupations that involve productive work and permit fuller family and personal life - such as mining, agricultural labor, factory work, or clerical employment-do not.

Colen \& Sanjek, supra note 35, at 6 (citation omitted). 
the respectability/degeneracy distinction that the domestic worker perilously challenged. ${ }^{71}$ The racialized nature of the servant and master class involved not only relegating persons constructed as non-white to domestic work, but also using the ideology of race to determine the interaction between master and servant. The race ideology became particularly useful for employers to achieve emotional distance from those persons who were physically and intimately involved in the operations of their homes. ${ }^{72}$ Stigmatization of impurity and uncleanliness intersected class, gender, and racial hierarchies all for the purpose of assisting middle-class families in maintaining a distance from the domestic workers situated within the intimate confines of their homes. ${ }^{73}$ It is in the specific details of particular labor markets and the changes that occur within them that the full effect of stratified reproduction can be appreciated. ${ }^{74}$

In the Northeast, the story of domestic work is told through the lives of

71. Cf. MCCLINTOCK, supra note 48, at 165 ("Small wonder that female servants in Victorian households came to be figured by images of disorder, contagion, disease, conflict, rage and guilt. For this reason ... domestic space became racialized as the rhetoric of degeneration was drawn upon to discipline and contain the unseemly spectacle of paid women's work.").

72. The British historian, Deborah Valenze, detected the interaction of class and race ideologies in her study of domestic workers in the Victorian era.

[I]f servants could be seen as less than human, employers need not feel self-conscious or embarrassed to carry on their intimate lives in front of them. Reports of interaction between servants and their mistresses, admittedly scarce and not always reliable, nevertheless deserve close analysis. The language and tone of such evidence suggests deeper meaning rooted in an ideology of class and race. For in the eyes of many masters and mistresses, class did operate in ways parallel to racial categories; lower-class people were closer to nature and less pure and clean than the more civilized middle-classes. Female servants suffered from the double stigma of gender and class, and the effect was a foreignness approaching racial difference. The framework of Victorian sexuality subjected lower-class women to inferior status from every point of view.

VALENZE, supra note 56, at 174; see Henry Louis Gates, Jr., Editor's Introduction: Writing "Race" and the Difference it Makes, in "RACE," WRITING AND DIFFERENCE 5 (Henry Louis Gates ed., 1986) ("Race has become a trope of ultimate, irreducible difference between cultures, linguistic groups, or adherents of specific belief systems which- more often than not-also have fundamentally opposed economic interests. Race is the ultimate trope of difference because it is so very arbitrary in its application.").

73. The racial dimension to the stigmatization explains why the middle classes demonstrated their preference for whites by paying them higher salaries, by providing them better working conditions, and by using less demeaning job classifications. If the labor supply permitted the distinctions, white women performing domestic work were classified by their employers as housekeepers while African Americans or Mexicans were classified as laundresses, cooks, or servants. See Glenn, supra note 34, at 10-11. The story of the racial and gender division of reproductive labor is part of a larger story of the racial and gender division of labor in the newly industrialized economy. See Evelyn Nakano Glenn, Cleaning Up/Kept Down: A Historical Perspective on Racial Inequality in "Women's Work," 43 STAN. L. REV. 1333, 1336 (1991).

74. The racial/ethnic hierarchies among women found in reproductive labor in the home were embedded for many of the same reasons outside the home when women of the middle and upper classes ventured into the public sphere. Hoy presents such an example when she describes the making of the nursing profession in support of the Union army during the Civil War:

Afraid that the nursing experiment might fail if too many women of poor judgment secured hospital positions, [Dorthea] Dix set about looking for women of character, good health, and some experience. .

One result of such scrutiny was that the title "nurse" carried cachet. Some 20,000 women served the Union army in all capacities . . but only 2000 to 3000 were called nurses and were under Dix's supervision; these were "white women of the middle and upper classes." The other nine-tenths served as "matrons," "cooks," and "laundresses" and were African-American women (free or slave) and white working-class women.

HoY, supra note 50, at 47 (footnote omitted) (italics added). 
migrating women-white women who migrated from rural to urban areas, women who migrated from other countries to the United States, and African American women who migrated to the North from the South. Thomas Dublin's study, Transforming Women's Work, New England Lives in the Industrial Revolution, offers data useful to understanding and analyzing the cult of respectability with evidence that "immigrants predominated in Boston's female work force, accounting for almost 64 percent of all workingwomen [sic]."75 When native-born white women did work, they had a relatively broad range of occupations available to them; they found employment as "professionals, proprietors, and clerical and sales workers." ${ }^{.76}$ In contrast, African American women and immigrant women were highly concentrated in domestic work. ${ }^{77}$ Dublin reports that in 1860 in Boston, eighty-seven percent of working African American women were employed in some area of domestic work ${ }^{78}$ and that "[j]ust over eighty percent of all female servants were foreign-born."79 According to Dublin, "[t]he proportion of servants among native-born whites was less than half those among immigrants or blacks, whereas the proportion in white-collar occupations . . was more than four times as great." ${ }^{280}$ His evidence shows that native-born white women performed domestic work, but that they were not defined by, or confined to, domestic work. Moreover, when white native-born women did work in domestic work, they typically worked in professional- or merchant-class families that were wealthier than the families who employed African American domestic workers. ${ }^{81}$ Dublin supplements the statistics with telling contemporary testimony of the racial stratification in the women's labor market in general and the domestic labor market in particular. White native-born women could command higher salaries as domestic workers and even then would avoid it precisely because it felt like being a "slave" and was degrading. ${ }^{82}$

The statistical evidence is overwhelming that in the last half of the nineteenth century, the opportunities in the Northeast for working-class women to choose employment other than domestic work depended largely on the women's race and ethnic background. Dublin reports that among native-born working women,

75. DUBLIN, supra note 41 , at 158.

76. Id. at 236.

77. See Glenn, supra note 34 , at 8 .

78. See DUBLIN, supra note 41 , at 159 . He also provides evidence that they were concentrated in specific occupations of laundresses, cooks, and chambermaids. See id. As is indicated at infra notes 85-86, 90, in 1860, significant migration of African American women from the South to the Northeast had not yet occurred. African American women made up only about one percent of the female labor force in Boston in 1860. See DUBLIN, supra, at 161

79. Id. at 161 ; see id. at $198-99$ (providing further statistical evidence of how the race and ethnicity of domestic workers changed between 1860 and 1870).

80. Id. at 158 .

81. See id. at 202; see id. at 199 (showing that for the less wealthy families, it became more difficult "to find" native-born white women to be domestic workers and referring to a Boston lady of the time who is quoted as saying, "[w] $w$ hen no more American servants could be found, like everyone else we had Irish, in fact, they were the only ones available").

82. See id. at 162; see ROMERO, supra note 36 , at 62 (reporting that women avoided domestic work or left it at the first opportunity notwithstanding the relatively higher pay). 
less than a sixth were employed as domestic workers in $1900 .^{83}$ This was true whether they were of native-born or immigrant parentage. ${ }^{84} \mathrm{He}$ also indicates by contrast that "[a] majority of immigrants ... . worked as servants, and among African Americans the proportion exceeded three-fourths." 85 Similar racial stratification occurred in other northern cities (in New York City in 1900, eightyfour percent of African American women were in domestic work; in Pennsylvania in 1890 the figure was ninety-one percent). ${ }^{86}$

World War I marked a shift in the demographics of domestic work in the Northeast and Midwest. ${ }^{87}$ It became more difficult to hire European immigrants

83. See DUBLIN, supra note 41 , at 243 ; id. at 245 (showing that, in 1900 , "[a]mong the foreign-bom [working women], a scant 7 percent found employment in white-collar clerical or sales occupations. For the native-born, whether of native-bom or immigrant parentage, about 29 percent enjoyed the better wages and working conditions of clerical and sales jobs."); id. at 253 (showing that, in 1900, "[n]ative-born daughters of immigrants most often found work in factories, whereas immigrant women divided their employment almost evenly between domestic service and factory work.").

84. See GLENN, supra note 41 , at 103.

For European women, domestic work functioned as a starting point for both the individual and the group. Most European immigrant domestics were young, single, live-in workers. The typical servant entered service upon leaving school in early adolescence and worked until her early or mid-twenties. After marriage she left service and usually did not return. In addition, although an immigrant woman might not move up the occupational ladder, her daughter usually did. American-bom daughters of immigrants for the most part shunned domestic service and entered the expanding white-collar fields of clerical and sales employment. Thus, the group's involvement in domestic service continued only Id. as long as new immigration from the mother-country continued.

85. DUBLIN, supra note 41, at 243; see also JACQUELNE JONES, LABOR OF LOVE, LABOR OF SORROW: Black WOMEN, WORK, AND THE FAMILY FROM SLAVERY TO THE PRESENT 161 (1985) ("[F]or the most part, black female wage earners remained outside the expanding industrial economy, and the few who gained a foothold in factory work remained in the lowest-paying jobs."); RoLLINS, supra note 38, at 52 (describing the particular stereotyping of Irish immigrant women and how the anti-Irish and antiservitude prejudices reinforced each other). The following unattributed quote captures the constitutive nature of ethnocentrism and domestic work: "The Irish seemed more lower-class because they were in domestic labor, and the work itself seemed more menial because the Irish dominated it." Id.

86. See DUBLIN, supra note 41, at 238; see also JONES, supra note 85, at 156 (reporting that in 1905 in New York, ninety percent of the African American working women were domestic workers). From the Civil War through the first half of the twentieth century, thousands of African American women migrated to northern cities. See id. at 155. The women tended to be young and unmarried, moving from Virginia and the Carolinas to Philadelphia, New York, or Boston. See id at 156.

The manner in which African American women in New York City were strictly confined to domestic work in the early part of this century is usefully compared to the experiences and opportunities, as described by Miriam Cohen, of Italian immigrant women during that same period:

In the United States by the turn of the century, servantry was not considered an acceptable option by many white working-class females. Manufacturing jobs meant shorter hours and at least some freedom from supervision, and such work allowed women to live at home with their parents. As more factory work became available, females of all ethnic groups chose the workshops. Unlike many Irish women in the nineteenth century and Polish women in the early decades of the twentieth, Jewish and especially Italian women emigrated almost exclusively in family groups or to join family groups already in America. These family connections meant that Jewish and Italian women did not need domestic service to supply room and board as well as wages.

MIRIAM COHEN, WORKShOP TO OFFICE: Two GENERATIONS OF ITALIAN WOMEN IN NEW YORK CITY, 1900 1950, at 53 (1992) (footnotes omitted).

87. See ROLLINS, supra note 38 , at 54; see also JONES, supra note 85 , at $156-57$ (describing the Great Migration during World War I (1916-1921) in which about five percent of the total southern African American population migrated north, which was more than the number of African Americans who had migrated north during the preceding forty years; they came from the deep South and a greater proportion of them chose midwestern cities; reporting further that by 1920 the black communities in New York, Chicago, and 
and their families as domestic workers for two reasons. First, the women had the opportunity to leave these jobs when they married, and changes in the labor market allowed their daughters to find manufacturing, clerical, or sales jobs. ${ }^{88}$ Second, limitations on immigration instituted in World War I dramatically reduced the supply of women immigrants available. ${ }^{89}$ The closing of U.S. borders to immigrants combined with the migration of African Americans to the North resulted in African American women comprising a significant percentage of domestic workers outside the South. ${ }^{90}$ This combination of factors reinforced the racial division of reproductive labor. ${ }^{91}$ Racial stratification in domestic work, of course, was concomitant with discriminatory employment practices by northern factory, sales, and clerical employers against African American women. $^{92}$

Racial stratification also occurred in the Southwest, the West, and the South, but marked differences in the domestic labor markets existed. In the Northeast,

Philadelphia "were larger than any in the South," but "no more than 9 percent of the total population of any urban area in the North... [was] black").

88. See Glenn, supra note 34 , at 11

89. See id.

90. See Rollins, supra note 38 , at 54 . Jacqueline Jones provides strong statistical data showing the predominance of African American women as domestic workers in the North and Midwest.

The exploitation of black domestics was thus a national, rather than a southern, phenomenon. In the three largest northem cities-New York, Chicago, and Philadelphia-the total number of servants declined by about 25 percent (from 181,000 to 138,000 ) between 1910 and 1920 , but the proportion of black women in that occupational category increased by 10 to 15 percent. After World War I, black women constituted more than a fifth of all domestics in New York and Chicago, and over onehalf in Philadelphia. ... [I]n 1920 fully 90 percent of black women in that city made their living as day workers, washerwomen, or live-in servants. The 108,342 servants and 46,914 laundresses not in commercial laundries totaled almost two-thirds of all gainfully employed black women in the North.

JONES, supra note 85, at 164 (footnote omitted); see also Elizabeth Clark-Lewis, "This Work Had a End": African-American Domestic Workers in Washington, D.C., 1910-1940, in TO TOL THE LIVELONG DAY, supra note 55, at 196, 197-98 (providing further supporting data that "African-American women were forced into a 'servant caste."'(citation omitted)).

91. See Clark-Lewis, supra note 90, at 202-03 (demonstrating that migrant African American women perceived the white mistresses as engaging in more degrading practices against them as compared to African American women not born in the South because they knew how important the job was to them and that it would not be easy for them to leave); see also id. at 203-12 (outlining benefits for migrant women of household day work as compared to live-in work, changes that occurred in their lives by the move to day work, and the strategies they used that allowed them to attain day work).

92. See JONES, supra note 85 , at 154 . Jones provides data that serves as telling evidence of discriminatory employment practices

[L]ess than 3 percent of all black working women were engaged in manufacturing in 1900 compared with 21 percent of foreign-bom and 38 percent of native-born white working women. By 1930 the comparable figures were 5.5 percent of gainfully employed black women (100,500 out of $1,776,922), 27.1$ percent of foreign-born, and 19 percent of native-born white women. (These figures reveal the impact of the last group's opportunities in sales and clerical work.) Black women, about 10 percent of the total American female population, constituted only 5.4 percent of the country's female manufacturing workers and only 0.5 percent of all female employees in clerical occupations, though they were gainfully employed in disproportionately large numbers overall.

Id. at 166; see also id. at 178-80 (describing further discriminatory hiring policies); id. at 200 (footnote omitted) (reporting that "[i]n 1940 one-third of all white, but only 1.3 percent of all black, working women had clerical jobs. On the other hand, 60 percent of all black female workers were domestic servants; the figure for white women was only 10 percent"); Clark-Lewis, supra note 90, at 198 (explaining that "antimigrant biases in the established African-American communities" meant that the migrating women could seldom find work in African American-owned businesses). 
native-born working women of immigrant parentage found opportunities outside of domestic work. ${ }^{93}$ In contrast, children and grandchildren of Mexicans who found themselves in United States' Southwest territories, either because of having been conquered or of having migrated, remained in domestic work. ${ }^{94}$ The same systematic restrictions were experienced by women who migrated from China, Japan, Korea, and the Philippines to Hawaii and California, ${ }^{95}$ suggesting that the stratified labor market persisted because some groups were racially and ethnically identifiable. ${ }^{96}$

In the Southwest, during the last half of the nineteenth century and the first half of the twentieth century, Chicanas were disproportionately represented in domestic work. ${ }^{97}$ White native-born or immigrant women were preferred, especially for work as nannies, leading to substantially lower salaries and less desirable positions for Chicana domestic workers. ${ }^{98}$ Private enterprise bringing industrialization to the West as well as public education programs were designed to teach domestic skills to the wives and daughters of Chicanos who were hired as miners or as other similar types of laborers. ${ }^{99}$ Chicanas were thought to be particularly well suited to domestic work once trained to clean in accordance with "American standards." 100 The tracking of Chicanas into domestic work continued throughout the depression years of the 1930s under the auspices of the WPA. $^{101}$

In the West, especially California and Hawaii, the largest immigrant groups of men were from Asian countries. ${ }^{102}$ Immigration laws prevented the immigration of families leading to a scarcity of women to do domestic work. Unique in this geographical area, white households hired Chinese men in the late nineteenth century and Japanese men in the early twentieth century to perform domestic

93. See supra note 84 and accompanying text.

94. See GLENN, supra note 41 , at 11 .

95. See id. at $11,23$.

96. See id. at 4-5, 11; see also id. at 23 (describing the industrial development in the West and the economic and political relations of the United States with countries in Asia that created the supply of cheap immigrant labor).

97. See id. at 101 (reporting that "[i]n El Paso, Texas . . Spanish-surnamed females accounted for 65.4 percent of all servants and 64.8 percent of all laundresses in 1910."); ROMERO, supra note 36, at 80 (reporting that in Santa Fe between 1860 and 1880, "the proportion of women with Spanish surnames who were engaged in domestic service almost doubled, from twenty-five percent to forty-eight percent").

98. See ROMERO, supra note 36 , at 80,81

99. See id. at 81,84 .

100. See id. Romero elaborates:

[d]uring the post-World War I period, middle-class white Americanizers continued to view Chicanas and Mexican immigrant women as dependent, inferior females who would be improved by exposure to "American" standards of housekeeping and parenting . . . Self-righteous mistresses actually justified paying low wages on the basis that domestic service would teach skills for social mobility and provide moral benefits to Mexican servants.

Id. at 83-84.

101. See id. at 84-85; Glenn, supra note 34, at 12; see also GLENN, supra note 41, at 103-04 ("Mexican American women... [were] ghettoized in the ethnically segmented labor markets of the Southwest, experienc[ing] virtually no mobility out of domestic and other service occupations.").

102. See GLENN, supra note 41, at 22-23 ("[A] large[] international movement of labor from Asia to the United States . . took place between 1850 and the mid-1930s."). 
work. ${ }^{103}$ Early in the twentieth century, a substantial number of Japanese women immigrated and close to half of all who did became employed either as servants or laundresses. ${ }^{104}$

In the South from the Revolution through the Civil War, enslaved African Americans predominantly performed domestic work under cruel, harsh, and unmerciful conditions. ${ }^{105}$ After Emancipation, African Americans remained in domestic work in the South, which had an exceptionally high ratio of domestic workers to households. ${ }^{106}$ Through the first half of the twentieth century, nearly every southern middle-class housewife employed an African American woman to clean and care for her children. ${ }^{107}$ In addition, it was not uncommon for working-class whites to hire African American women as housecleaners. ${ }^{108}$ Jacqueline Jones reports, however, that in the late nineteenth century in the Cotton Belt African American women found alternatives to doing domestic work in the homes of whites:

Husbands preferred that their wives not work directly for whites, and, if they had to, that they labor in their own homes (as laundresses, for example) rather than in a white woman's kitchen. . . [R]elatively few Cotton Belt women worked regularly as servants for whites $(4.1$ percent in 1880; 9 percent in 1900), some performed day service during the slack season. ${ }^{199}$

The pervasive and tenacious racial stratification of reproductive labor and how it contributed to the making of the middle class is demonstrated by the reaction of the white middle classes to African American women who withdrew from waged labor to care for their own families. ${ }^{110}$ Employers showed "their contempt for freedwomen who 'played the lady' and refused to join workers in the field."

103. See Glenn, supra note 34 , at 9 .

104. See id. at 9; see also GLENN, supra note 41 , at 6 (footnote omitted) ("In the years before World War II, over half of all employed Japanese females in the Bay Area, both foreign- and native-born, were found in domestic work."). Intergenerational mobility from domestic work into other occupations was not as easily achieved for Japanese women as it was for European women. Their daughters and granddaughters, however, had more employment opportunities than did African American women and Chicanas. See GLENN, supra, at 104-05.

105. See ROLLINS, supra note 38 , at 51

106. See id. at 51

107. See JONES, supra note 85 , at 128 ; Glenn, supra note 34 , at 10.

108. See JONES, supra note 85 , at 128 ; Glenn, supra note 34 , at 10.

109. JONES, supra note 85 , at 90.

110. See id. at $\mathbf{5 8}$.

111. Id. at 59. The contempt by whites for African American women who stayed at home continued into the next century. Jones tells of an interview with a Chicago stockyard worker who had left Mississippi during the Great Migration north. He told an interviewer for the Commission on Race Relations that

Men and women had to work in the fields. A woman was not permitted to remain at home if she felt like it. If she was found at home some of the white people would come to ask why she was not in the field and tell her she had better get to the field or else abide by the consequences. After the summer crops were all in, any of the white people could send for any Negro woman to come and do the family washing at 75 cents to $\$ 1.00$ a day. If she sent word she could not come she had to send an excuse why she could not come. They were never allowed to stay at home as long as they were able 
When white employers used the term "lady" in reference to black women it was used for sarcastic and derisive purposes and meant as a criticism for her being lazy. ${ }^{112}$ This type of ridicule, of course, served a dual purpose of denigrating unwaged labor in the home as well as reinforcing the white male's superiority in the public marketplace through racial subordination.

Also worth noting is the effect of the African American urban migration during Reconstruction. Fleeing the rural areas to seek food and safety, they were met with considerable hostility by whites who "believed that the city was 'intended for white people." 113 The lack of housing and employment opportunities resulted in an exodus of African Americans back to farm work in 1866 and 1867, but nevertheless the urban population of African Americans increased significantly during the 1860 s, especially in the larger southern cities. ${ }^{114} \mathrm{~A}$ high ratio of those who stayed were women who found it difficult to support themselves and their children in rural areas. ${ }^{115}$ In these southern cities most of the women were employed as servants or laundresses, with a small minority working as cooks, nurses, seamstresses and unskilled laborers in factories. ${ }^{116}$ Notwithstanding the dramatic changes that occurred in the late nineteenth century regarding white working women's employment opportunities, the labor story of African American women, as Jacqueline Jones forcefully demonstrates, "exhibited striking continuity across space-urban areas in the North and South-and time-from the nineteenth to the early twentieth century."117

to go. Had to take whatever they paid you for your work. Id. at 157 .

112. Id. at 59 .

113. Id. at 73 .

114. See id.

115. See id.

116. See id. at 74. One survey found that servants represented about half of all African American working women in the seven cities studied and laundresses another one-fifth. Id. The heavy toll of this work on African American women and their families cannot be overstated. As reported by Jones, part of what accounts for the disproportionately low fertility rates for African American urban women in the South at the turn of the century was the work they performed in domestic service.

One black physician familiar with the living conditions and work responsibilities of black women in southern cities made this bitter observation in 1896 :

As to still-births: Why should we be surprised at the great number of still-births among our women, since they do most of the work that is liable to produce this state of things? They do the cooking, the sweeping, the lifting of heavy pots; they carry the coal, the wood, the water; they carry heavy burdens on their heads; they do heavy washing, make beds, tum heavy mattresses, and climb the stairs several times during the day, while their more favored white sister is seated in her big armchair, and not allowed to move, even if she wanted to.

Id. at 123. See also id. at 128-34 (describing the African American woman's working conditions, the stress of balancing the need for a cash income by leaving her home with the needs of her children of having her care, and the slavery legacy inherent in the relationship of employers and employees).

117. Id. at 161; see also GLENN, supra note 41, at 103 (describing how marriage did not mean that an African American woman could withdraw from waged labor because her earnings remained necessary for the support of the family and how the exclusion of African American women from factories, offices, and stores until the 1950s resulted in they and their daughters and granddaughters being confined to domestic work or related employment). 
The gender and racial stratification of domestic work in the United States did not, of course, occur solely through private arrangements. State and federal governments also played a role. As already noted, U.S. labor history of domestic work was affected by wars, immigration policies, among other factors. The governmental role in perpetuating the respectability/degeneracy distinction is revealed most obviously in the implementation of social programs during the first half of the twentieth century.

\section{Social Programs During the First Half of the Twentieth Century}

The gender and racial stratification of domestic work not only affected the labor market; it controlled all matters of social and public policy. For example, African American mothers and mothers who had immigrated from Mexico were excluded from government pension programs that were designed to assist mothers after World War I. ${ }^{118}$ The majority of the recipients of these pensions were European immigrant mothers. ${ }^{119}$ Gwendolyn Mink reports that in Los Angeles, county officials justified excluding Mexican widows on the ground that their "feudal background" made it "difficult for them to "understand not to abuse the principle of a regular grant of money from the state. ${ }^{\prime \prime 20}$ Not a single African American family received a pension in Houston, Texas, in 1920, even though they comprised twenty-one percent of the population. ${ }^{121}$

The prevailing stereotype that led officials to deny African American women eligibility status was that they were self-supporting as domestic workers. ${ }^{122} \mathrm{~A}$ field supervisor overseeing the Aid to Dependent Children program was reported to have said:

The number of Negro cases are few due to the unanimous feeling on the part of staff and board that there are more work opportunities for Negro women and to their intense desire not to interfere with local labor conditions. ... There is a hesitancy on the part of the lay boards to

118. See generally Gwendolyn Mink, Welfare Reform in Historical Perspective, 26 CONN. L. REV. 879, 886 (1994) (critiquing maternalist policymakers' challenge to white men's democracy as "constrained by its gender, cultural, and racial prescriptivity").

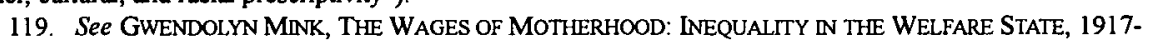
1942, at $49-50$ (1995) (reporting that only 3\% of the recipient population in 1931 were African American mothers and $50 \%$ of them lived in just two states, Pennsylvania and Ohio); see also Lucie E. White, On the "Consensus" to End Welfare: Where are the Women's Voices?, 26 CONN. L. REV. 843, 845-47, 853-54 (1994) (describing the work of elite and middle-class women during the Progressive Era and their role in developing the mothers' pension programs and the racially discriminatory operation of the programs and noting that only after World War $I$ did the Aid to Families with Dependent Children [AFDC] program begin to address the needs of African American women through the influence of the civil rights movement and the legal aid/legal rights movement).

120. MNK, supra note 119 , at $49-50$.

121. See id. at 50 .

122. See WINFRED BELL, Am TO DEPENDENT CHILDREN 174-94 (1965); MINK, supra note 119, at 50 (citing the practices of Chicago officials as an example); FRANCES FOX PIVEN \& RICHARD A. CLOWARD, Regulating tHe POOR: THE Functions OF PUBLIC WELFARE 138 (1971). 
advance too rapidly over the thinking of their own communities which see no reason why the employable Negro mother should not continue her usually sketchy seasonal labor or indefinite domestic service rather than receive a public assistance grant. ${ }^{123}$

At the same time that the middle-class homemaker denied the domestic worker's agency in order to preserve the homemaker's and family's superiority, the federal government was attributing to her full agency as a worker who was not in need of public assistance. The two views are not in conflict. Both characterizations depended on denying the domestic worker her claim to being a woman and a mother; both depended on making the reality of the domestic worker's life invisible; and both served the economic and social interests of the white middle class.

Notwithstanding the New Deal and the accompanying surge in labor regulation, domestic work remained beyond the reach of federal, state, or local government regulatory control. Relying on the assumption that domestic work belonged to the private sphere, lawmakers rationalized that governmental intervention into citizens' homes was unfeasible and, therefore, made no efforts to improve the working conditions of waged household work. ${ }^{124}$ Phyllis Palmer revealingly describes the efforts of non-governmental organizations formed in the late 1920 s to address the need to improve the wages and working conditions of household workers. Their major goal, pursued throughout the 1930s, was "to achieve formulation and widespread adoption of model contracts for the voluntary use of housewives and household workers." ${ }^{25}$ Their project failed because the groups representing the workers and those representing the housewives could not agree on the length of the work day and the work week. ${ }^{126}$ "Employers consistently refused to adopt business standards of set hours and organization for the work of the household, apparently because of the endlessly expansive demands made on women, primarily by their husbands and children. . . . [T] he middle-class woman who could afford to hire help was looking for a clone: a woman who could do things as she herself did them, for the hours that were expected of her ...."127 Although Palmer suggests that the interracial work of the organizations, particularly the YWCA, had a long-term impact on its work for racial justice, she concludes that the exchange of stories between workers and employers "failed to change . . . the middle-class feeling that the only solution [to the demanding and expansive nature of housework] was to pass on as much of the work as possible to another woman." 128

123. MNK, supra note 119, at 143 (quoting Mary S. Larbee, Unmarried Parenthood Under the Social Security Act, NAT'L CONF. SOC. WORK PROC. 434 (1939)).

124. See Palmer, supra note 55, at 180-81; see also id. at 191 (reporting that domestic work was excluded by the unemployment provisions of the Social Security Act along with agricultural labor).

125. Id. at 184

126. See id. at 184-88, 192-95.

127. Id at 193-94.

128. Id. at 195 . 
Concern during World War II that domestic labor would no longer be widely available at a low cost affected labor mobilization efforts. The government, through training programs and propaganda, supported private employers and white workers who were comfortable with existing racial hierarchies in the labor market. ${ }^{129}$ For example, Japanese American women found themselves channeled into domestic work during and after World War II. Accepting these positions made it possible for them to leave the internment camps. Even after the camps were closed, government agencies established to assist them directed them to domestic work jobs. ${ }^{130}$ These efforts were frequently rationalized as being in the women's own best interests. Although different racial stereotypes and characterizations were used for different groups of women, what was clear was that their "best interests" coincided with the belief that the proper role for these women was serving the needs of white families. ${ }^{131}$

Concomitant with federal government programs directing women of color into domestic work was the absence, subsequent to World War II, of protections for domestic workers otherwise available in many other industries. ${ }^{132}$ White employers that expected wages for domestic work would decrease subsequent to the war. "Reports abounded of housewives who immediately lowered the pay of servants as soon as the Japanese surrendered . . .."133 Many African American

129. See Glenn, supra note 34 , at 11 (referring to programs tracking Chicana students into homemaking courses). Jones provides yet another dimension of governmental involvement in the racial stratification of the work force:

From official United States government posters to short stories in popular women's magazines, recruitment propaganda was aimed exclusively at white women of both middle and working classes. When black women were mentioned in connection with the national manpower crisis at all, they were exhorted to enter "war service," by taking jobs that white women most readily abandonedlaundry, cafeteria, and domestic work.

JONES, supra note 85, at 236-37.

130. See Glenn, supra note 34 , at 13 .

131. See id. at 14. Jones elaborates on this point by describing African American women's work experience during the war:

By 1944 black women constituted 60 percent of all private household workers (up 13 percent over the figure for 1940), reflecting white women's hasty flight from service as soon as the Great Depression ended. Black women also filled a disproportionate number of institutional service jobs as a result of the "secondary boom" in the restaurant, lodging, and custodial services industries. For the first two and a half years of the war, especially, when defense plants hired any black women at all, they used them as scrubwomen or janitors and kept them in these jobs for the duration of the conflict. Institutional service jobs offered more in the way of higher wages and on-the-job companionship than private domestic employment; even better, a blue-collar job beat making beds or "busting suds" for anyone.

JONES, supra note 85 , at 237-38

132. See JONES, supra note 85 , at $257-58$. Reformers focusing on mother-directed child welfare policy in the 1930s and 1940s

believed women ought not to work, although sometimes they "needed" to, and therefore [they] . . . did not contest the omission of women from policies developed for workers. The only occupational exclusion seriously challenged by maternalists was the exclusion of domestic work under the Social Security Act. This limited defense of women as workers coincided with a long-standing, separate conception of Black women (a third of all domestic workers) as workers rather than mothers. Perhaps it also coincided with the reformers' view that for some women to work in other women's homes promoted legitimate interest in child and family welfare.

MiNK, supra note 119, at 172 .

133. JONES, supra note 85, at 258. 
women refused to return to domestic work even when the pay remained relatively favorable as compared to factory and laundry workers. ${ }^{134}$ The government's response through the Women's Bureau was to try to convince women, especially African American women, that the work was not degrading. Its dual concerns were to address the anxieties of upper middle-class women who needed (wanted) inexpensive labor and those of African American women who would find it difficult to support themselves if they rejected domestic work as an alternative. ${ }^{135}$ Jones reports, however, that the government's efforts were unsuccessful because employers failed to cooperate and to provide fair wages and reasonable working conditions for those they hired to perform domestic work. ${ }^{136}$

The U.S. history of domestic work from the last half of the nineteenth century until World War II tells an unrelenting story of gender and racial stratification that serves the interest of the middle class. The cumulative data challenges the myth that respectability is earned through hard work and dedication to family and is achievable only by those with good character. The data also challenges the myth that those categorized as degenerate deserve disrespect. What the data shows is that the claim of respectability by the middle class depended ideologically and materially on a class of persons that established respectability for the middle class by being denied it for themselves.

As we will see in the following section, since World War II, domesticity, motherhood, and respectability took on different meanings and supported different practices than they did in the earlier part of the century. As we will also see, however, waged child-care arrangements continue to reflect the class, gender, and racial hierarchies. Data on the U.S. labor market of domestic work after World War II challenge conventional understandings of work and family and lead to a reconsideration of the respectability/degeneracy distinction and the role it may be playing in contemporary tax law.

\section{B. The Market for Child-Care Services from World War II Through the Present Day}

\section{The Reconfiguration of the Respectability/Degeneracy Distinction}

Dividing the story of women's involvement in market work into pre-World War II and post-World War II periods replicates the scholarly literature on women in the United States workforce. ${ }^{137}$ The conventional view is that the war period

134. See id.

135. See id.

136. See id. at 258-59. African American women's working conditions were improved mostly by groups in the African American community organizing to provide training and placement services, to maintain living wages, and to monitor employers who exploited their workers. See id. at 259.

137. See Diane E. Herz \& Barbara H. Wootton, Women in the Workforce: An Overview, in THE AMERICAN WOMAN, 1996-97 at 44, 46 (Cynthia Costello \& Barbara K. Krimgold, Women's Research and Education Institute eds., 1996). 
was "a watershed in women's involvement in market work."138 As we have seen, however, women who were young, unmarried, foreign-born, or nonwhite participated in waged labor in large proportions throughout the late nineteenth and twentieth centuries. To avoid universalizing the experiences of white, U.S.born, middle-class, married women, it is more accurate to see World War II as an important milestone in women's labor history because of its effect on the cult of respectability.

Respectability becomes reconfigured, in part, by the operation of three related developments during the postwar period. One is the spread of industrialization into the home by transferring reproductive labor from the home into the marketplace. ${ }^{139}$ From grocery and convenience stores to restaurants and health clubs, families have been able to purchase many services for the household outside the home. These services, along with technological labor-saving devices, including freezers and frozen foods, automatic washers and permanent-press clothes, microwaves, vacuum cleaners, and dishwashers, have been the industrial response to the household domestic worker. ${ }^{140}$

Cooks are no longer found in the kitchens of those in the middle class. Instead, they work in large industrial kitchens producing packaged food or in restaurant kitchens producing ready-to-eat food. ${ }^{141}$ The shift of reproductive labor to the non-household marketplace, generally, has improved the nature of the work, the working conditions, and its status. ${ }^{142}$ Gender and racial stratification of reproductive labor, however, has remained intact. Although substantial progress has been made with regard to gender and racial discrimination in employment, statistics also reveal that gender and racial divisions in the labor market remain prevalent. ${ }^{143}$

The substitution of non-household market services and commodities for domestic workers has coincided with a labor shortage for household domestic workers. That labor shortage is attributable, in part, to an economic expansion that provides greater employment opportunities for women of color and, in part, to changes in discrimination laws that provide women of color greater access to education and jobs. Thus, the second development affecting the cult of respectability in the postwar years is the representation of women of color in all occupational categories. ${ }^{144}$ Although domestic work and race continue to be

138. Id. at 46

139. See HoY, supra note 50, at 152; Glenn, supra note 34, at 5; ROMERO, supra note 36, at 64-65.

140. See ROMERO, supra note 36 , at 65-66.

141. See Glenn, supra note 34 , at 5-6.

142. See id. at 22-23.

143. See id at 19-22

144. See Glenn, supra note 73 , at 1346 , tbl. 2 . In 1994, about six of every ten white women participated in the labor force. The same proportion of African American women participated. See Herz \& Wootton, supra note 137 , at 50 . Women of Hispanic origin participated at a slightly lower rate (53\%). See id. at 50 .

Of all African American women workers in 1960, 36.2\% were private household workers. That percentage decreased to $5 \%$ by 1980 . See Glenn, supra note 73, at 1345. In 1980, of Mexican women workers in El Paso, 2.1\% were household domestic workers. See id. These declining percentages are contrasted with the increasing percentage of women of color in occupations that have traditionally been filled with white 
mutually constitutive, the inferiorization of domestic work is not occurring at the same level of intensity or pervasiveness.

These two developments-industrialization of reproductive labor and improvement in the occupational opportunities available to women of colortogether signify that the middle class status is no longer equated with the presence of domestic workers in the home. Instead, middle-class status can be acquired through the acquisition of commodities that produce reproductive labor themselves. The more commodities the family acquires - the dishwasher, garbage disposal, lawn-sprinkling system-the more it can be assured of its distinctive status from the working class. With respectability and cleanliness remaining firmly linked, commercial messages by firms suggesting that their products, with minimal effort on the consumer's part, can achieve "cleaner than clean" are particularly attractive. The underlying meaning is that industrialization has provided the solution to the middle class's conundrum of being able to achieve cleanliness only by allowing the unclean to cross their thresholds. Preoccupation with the acquisition of reproductive goods and services produced and sold in the non-household marketplace contributes, in part, to the third development affecting the cult of respectability.

The third development is the entrance of white, middle-class, married women, in greater numbers and at a faster rate than any other demographic group, into the work force. ${ }^{145}$ Given the racial stratification of the labor force for both women and men, it would be far too simplistic to equate the experiences of many white married women entering the work force with those of married women of color. White men historically have been the highest earners in the labor force. ${ }^{146}$ They and their wives, therefore, have been in a better financial position to decide to forgo a second worker's earnings and have the wife remain at home to care for their children. In a comparison by race of the median weekly earnings of

workers. Of all African American women workers, less than $9 \%$ were in clerical positions in 1960 compared to $28 \%$ in 1987 . See id. Hispanic working women have enjoyed some success in overcoming discrimination barriers. The proportion of Hispanic working women in managerial or professional positions increased $61.2 \%$ between 1983 and 1987. See id.

145. See Susan M. Hartmann, Women's Employment and the Domestic Ideal in the Early Cold War Years, in NOT JUNE ClEAVER: WOMEN AND GENDER IN POSTWAR AMERICA, 1945-1960, at 84, 86 (Joanne Meyerowitz ed., 1994). In 1900, approximately $19 \%$ of women were in the waged labor market. Most of them were unmarried and without children. See Diana Furchtgott-Roth, Working Wives Widen "Income Gap", WALL ST. J., June 20, 1995, at A18. In contrast, between 1969 and 1993, the percentage of working-age married couples with two earners rose from $49 \%$ to $72 \%$. See id. In $1994,75 \%$ of women with children over six performed waged work. See id; see also Robins, supra note 11, at 344 (providing further data demonstrating the increased labor force participation of women with children); Herz \& Wootton, supra note 137 , at 52 ("[I]n 1994, 70 percent of women with children under age 18 participated in the workforce, compared with 85 percent of those without children."). The percentage of mothers with children under age 6 in the labor force has also increased. The percentage increased from 28.7 in 1970 to 58.2 in 1990 . See Jonathan R. Veum \& Philip M. Gleason, Child Care: Arrangements and Costs, MONTHLY LAB. REV., October, 1991, at 10. See also Herz \& Wootton, supra, at 52 (reporting that in $1994,60 \%$ of mothers with children under six were in the workforce compared with $39 \%$ in 1975 ; more than $50 \%$ of mothers with children under age one were in the workforce).

146. See Glenn, supra note 73, at 1348-49; Dorothy A. Brown, Race, Class, and Gender Essentialism in Tax Literature: The Joint Return, 54 WASH. \& LEE L. REV. 1469, 1489 (1997). 
husbands whose wives did not have waged employment, the data provides further support that the relatively higher income of a white husband gives his wife more choices in deciding whether to work and how much to work. White husbands' median weekly earnings were $\$ 511$ in 1989 while the median weekly eamings of African American and Hispanic husbands were $\$ 360$ and $\$ 332$, respectively. ${ }^{147}$

Not only have the economics of the decision to enter and stay in the work force been different for white women as compared with women of color, but the political and social consequences of white, middle-class women venturing out of their domestic settings into the public marketplace have also been different. When they leave their homes, they transgress the customs of ladyhood. ${ }^{148}$ Although some may have done so enthusiastically while others may have done so with some regret, what is detectable in the last half of the twentieth century are the efforts of the middle class to draw yet another distinction between what I would term the lady-like worker and the working-class woman. Confounding contradictions arose when working-class women crossed the threshold into the middle-class home; they also arose when the lady crossed her own threshold to go into the marketplace. In both instances, strategies were necessary to mask the similarities and to display the distinctions in order to justify a claim for respectability.

Notwithstanding that substantial numbers of middle-class women are entering the work force in the postwar years, respectability, with an emphasis and celebration of a gendered domesticity, retains its persuasive power. In the 1950s, during the height of the Cold War, "[n]ational leaders as well as popular culture proclaimed that women's role in the international crisis was to strengthen the family and raise new citizens emotionally and mentally fit to win the Cold War." 149 Public opinion constructed the good care, the nurturing, and the education of children as a matter of national security and that mothers were meeting their patriotic duty by meeting their family duties. The famous "kitchen

147. See Glenn, supra note 73 , at 1349 , table 4 ; see also id. (reporting that in 1989 , the median weekly earnings of a two-earner couple both of whom are white was $\$ 867$ as compared to $\$ 753$ for an African American couple and $\$ 680$ for an Hispanic couple). But see Robert Rector, Fourteen Myths about Families and Child Care, 26 HARv. J. ON LEGIS. 517, 521 (1989) (stating that "[m]any traditional families are in fact among the least affluent of America's families. Among families with preschool children earning less than $\$ 15,000$ per year, traditional families outnumber families headed by employed single mothers.").

148. Married women's movement into the labor force has been attributed to the feminist and civil rights movements, the decline in birthrates, which both reflected and contributed to women's growing participation in the work force, and women's higher education levels. See Herz \& Wootton, supra note 137, at 46. Also affecting women's participation in the work force has been the changing nature of the American family. Marriage rates have declined and divorce rates have increased, peaking around 1980. See id. at 48 . Although married-couple families remain prevalent (77\% of all American families in 1994), "women who do not currently maintain households or families are more likely to plan their work lives with that possibility in mind." See id:; see also Robins, supra note 11, at 344-45 (suggesting a number of factors responsible for increasing female labor force participation; the factors suggested employ traditional micro-economic reasoning and rely on traditional stereotypes regarding women and work).

149. Hartmann, supra note 145, at 85 (citing ELAINE TYLER MAY, HOMEWARD BOUND: AMERICAN FAMILIES IN THE COLD WAR ERA (1988)). 
debate" in 1959 between Soviet Premier Nikita Krushchev and Vice-President Richard Nixon linked communism with women in the waged work force and consumerism, in the form of labor-saving home appliances, with freedom. ${ }^{150}$ The lady as homemaker was, in large measure, a thriving image and practice in the postwar years.

At the same time, however, the Cold War demanded that serious consideration be given to maximizing the country's human resources, which to policymakers meant considering women as participants in the work force. ${ }^{151}$ Susan Hartmann argues that "[in] an era dominated by the celebration of domesticity and women's traditional roles, experts and opinion leaders not only recognized and approved of women's increasing employment but also sought to adjust public opinion and public policy to accommodate women's greater participation in the public sphere."152 Whether one views the evidence as demonstrating ambivalence about the appropriate role of women or as a well-designed, twotrack policy, the practices and the rhetoric served to maintain the boundaries between the middle and the working classes. Not surprisingly, childcare became a primary boundary-making tool, which means that childcare, as a concept and a practice, necessarily has class, gender, and race implications. ${ }^{153}$

\section{The Federal Government 's Involvement in Childcare}

The Women's Bureau, which was established in 1920 as part of the Department of Labor, recognized that women in the waged labor force needed childcare. ${ }^{154}$ During World War II, when middle-class women were encouraged to enter the work force to assist the war effort, Congress funded day-care centers. ${ }^{155}$ Presumably, in a war-time economy when issues of domesticity lost sway and the need to encourage women to enter the work force was viewed as a matter of national security, government-provided day care was easily justified. Not surprisingly, the programs were terminated at the end of the war. ${ }^{156}$ No further action occurred at the federal level until 1954, when Congress provided for a tax deduction for employment-related child-care expenditures. ${ }^{157}$

The debate surrounding this tax deduction is revealing as to how the respectability/degeneracy distinction informed both sides of the arguments and

150. See Hartmann, supra note 145 , at 86 .

151. See generally id. (exploring the work of the National Manpower Council and the Commission on the Education of Women to demonstrate how the early Cold War years was a period of transition).

152. Id. at 86 .

153. See supra notes 38-136 and accompanying text providing an historical analysis of domestic work in the late nineteenth and early twentieth centuries that demonstrates the prevalence of a hierarchical construction of child care in the United States.

154. See Jlll Quadagno, The Color of Welfare 136-37 (1994).

155. See id. at 137. The Children's Bureau, Women's Bureau, and a host of other reform groups, however, resisted the development of a child-care policy. See MINK, supra note 119, at 164-66.

156. See QUADAGNO, supra note 154, at 137.

157. See Sar A. Levitan \& Frank Gallo, Work and Family: The Impact of Legislation (The American Family During the 20th Century), 113 MONTHLY LAB. REV., March 1990, at 34. 
thereby reinforced the distinctions between the middle-class lady, the lady-like worker, and the working-class woman. As first proposed, it was a deduction limited to actual expenditures up to $\$ 600$ and available only to widows, widowers, divorced or legally separated individuals, and waged working mothers whose husbands were incapacitated. ${ }^{158}$ The middle-class married woman whose husband earned a family wage was obviously excluded from benefiting from this proposal. The notion of creating an economic environment to enable mothers to have a choice between staying at home with their children and entering the work force was hotly contested. ${ }^{159}$ The legislative history also makes clear that it was beyond the ken of policymakers to attribute the need for childcare to the fact that the huband had entered the work force-the gendered division of reproductive labor remained intact.

Ultimately, Congress passed and the President signed a tax bill that contained a more generous deduction that covered middle-class working wives. A deduction of up to $\$ 600$ of child-care expenditures was allowed for families whose income was below $\$ 4,500$, and only families whose income exceeded $\$ 5,100$ were not allowed any deduction. ${ }^{160} \mathrm{~A}$ review of the hearings indicates that the debate concerned especially married mothers entering the work force and leaving their children under the care of someone else. For example, Congressman Noah H. Mason from Illinois argued at a House Ways and Means Hearing that:

I know of dozens of instances in my own little town where the mother learned she could earn money during World War II and now insists upon doing it while the children are running loose and becoming a nuisance in the town. I would not want to give that kind of mother any exemption for whomever she hires. But if it is a widow or widower ... I think he or she is entitled to it. ${ }^{161}$

Addressing a witness at the Hearing about whether married couples, regardless of their economic status, should qualify for a deduction for child-care expenditures, Congressman Mason later asked the following question:

158. See H.R. 8300, 83d Cong., 2d Sess. § 214 (1953); Hartmann, supra note 145, at 94-95.

159. See infra notes $161-66,257-60$ and accompanying text describing and quoting extensively from the legislative history that led to Congress's enactment of a deduction for employment-related child-care expenditures.

160. See S. REP. NO. 83-1622, at 35-36, 220-21 (1954), reprinted in 1954 U.S.C.C.A.N. 4666-67, 4856-58; Hartmann, supra note 145, at 95 (indicating that nearly half of all families had incomes below $\$ 4,500$ in 1954); see also Forty Topics Pertaining to the General Revision of the Internal Revenue Code Before the House Comm. on Ways and Means, 83d Cong. 27 (1953) [hereinafter 1953 Hearings] 62-63 (statement of Nancy M. Henderson) (arguing that "[b]ecause a woman has been able to acquire an education and has pursued a career along with her family, she should not be penalized because of her capability and ambition and the fact that she is earning a salary of $\$ 6,000$ or more" and responding to a question of whether a woman who marries should give up her career by saying " $[t]$ hat of course, is up to the individual's personal decision whether or not she wises to continue to do that. I don't think that the law should discriminate against her if that is what she wants to do").

161. 1953 Hearings, supra note 160, at 27 (statement of Noah M. Mason, Congressman from Illinois). 
But would you say we should go this far: A married lady insists upon working so that she can buy a $\$ 750$ fur coat because her husband cannot afford it. He is working; he is earning what we would call a good living, but she cannot afford these luxuries and she wants these luxuries and therefore she goes to work and earns for herself enough to get these luxuries, and she neglects her children or hires someone who is not capable of handling them and is letting them run the streets and thus bringing about juvenile delinquency? And I know of several cases of exactly that kind. Would you say this committee should step in and encourage that woman to continue to do that? ${ }^{162}$

Abuse of the tax deduction, by women who went to work to obtain luxuries or to send their children to fancy schools, was of major concern, as was the risk of child delinquency in the absence of a mother's supervision. ${ }^{163}$ The more liberal version of the bill passed through Congress because the participation of middleclass women in the work force was needed. The more liberal version was also passed because it was thought to be unfair not to view child-care expenditures as a necessary cost of earning income when other costs related to business activity, such as travel and country club memberships, were deductible. ${ }^{164}$

In contrast to the concerns expressed about middle-class married women and their children, there were no fears that children from poor and working families would not have the care and nurturing of their mother. The policymakers believed that the tax deduction would promote the welfare of the children and reduce delinquency by allowing their mothers to obtain adequate child supervision. ${ }^{165}$ No concerns were raised about poor and working-class women

162. Id. at $35-36$.

163. See id. at 53 (statement of Arthur G. Klein, Congressman from New York) ("Some of these women might decide they do not like housework and want to get a job. . . I don't think all women ought to get this exemption if they do not have to go out and get a job."); Hartmann, supra note 145, at 96.

164. See, e.g., id. at 30 (statement of Aime J. Forand, Congressman from Rhode Island) (when proposing a bill that limited the deduction to a parent whose spouse is either dead, divorced, or separated from the parent, arguing "[i]t is my belief that if as many mothers, for instance, had been working at the time that regulations were shaping the meaning of 'ordinary and necessary business expenses' as there are now, the Treasury Department would have permitted deductions for wages paid housekeepers, nursemaids, and expenses of nursery care"); id. at 31 (letter from Beryl S. Denzer, a mother with two small children) (referring to the inequity of allowing deductions for membership in country clubs but not deductions for childcare); id. at 38, 41 (statement of Kenneth A. Roberts, Congressman from Alabama) (referring to the deductibility of entertainment expenses as he argued on behalf of child-care deductions); $i d$. at 50 (statement of Julia Thompson, Representative of the American Nurses' Association) (criticizing Smith $v$. Commissioner (discussed infra notes 307-34 and accompanying text) and arguing that "equity demands that the working mother be put on a par with business and professional people with respect to deductions allowed"); id. at 61 (statement of Nancy M. Henderson) (comparing the cost of child care to the cost of a secretary hired by a business concem and arguing, as a matter of equity, against any income limitation being placed on the deductibility of child-care expenditures).

165. See 1953 Hearings, supra note 160 , at 34 (statement of James C. Davis, Congressman from Georgia) ("Without proper care, juvenile delinquency would increase by leaps and bounds."); id. at 58 (statement of Louis B. Heller, Congressman from New York) ("Leaving these children to themselves is an open invitation to the spread of juvenile delinquency."); cf. ROBERTs, supra note 47 , at 876-78 (scrutinizing current welfare reform thetoric and demonstrating that it is based on a historical and systemic stigmatization of 
entering the work force abusing the purpose of the legislation. On the contrary, the child-care deduction was viewed by some as a way to reduce welfare dependency and idleness. ${ }^{166}$

The debate, however filled with contradictions, consistently maintained the boundaries among the three types of post-war women. Tributes went to the lady who stayed home and cared for her children. Skepticism and charges of selfish consumption motives went to the lady-like worker. Her willingness to enter the work force was not viewed as an act of self-sufficiency or initiative. Rather she was seen as perhaps shirking her responsibilities at home. The lady-like worker lost some respectability when she crossed the threshold into the marketplace, but the rhetoric saved her from crossing yet another boundary-being a workingclass woman.

The most degrading arguments were reserved for the working-class woman. Nothing was lost to her, her children, or the nation when she entered the work force. For her not to enter the work force was an act of laziness. ${ }^{167}$ The assumption underlying this view of the working-class woman was that she was not a good mother. The assumption produced its own incongruity because some of these working-class mothers found employment by caring for the lady-like worker's children. ${ }^{168}$ That apparent contradiction was easily explained away, presumably by the fact that the child-care services were being provided under the supervision of the lady-like worker. In the end we are left with the ironic conclusion that one of the major pieces of federal legislation recognizing the child-care issues faced by all mothers in the waged work force was enacted in a manner that sustained the celebration of middle-class domesticity and reinforced the inferiority of working-class mothers. ${ }^{169}$

Black mothers as well as their children).

166. See 1953 Hearings, supra note 160, at 58 (statement of Welsey A. D'Ewart, Congressman from Montana) ("I recall very clearly one case . . . where the working mother paid so much for foster daytime care of her children that she would actually have been money ahead had she stayed at home in idleness and relied on the county welfare board to take care of her."); Hartmann, supra note 145, at 97.

167. See Joel F. Handler, Two Years and You're Out, 26 CONN. L. REV. 857, 857-60 (1994) (looking at the policies and rhetoric of the nineteenth and early twentieth centuries and how they produced the "deviant class" of poor single mothers and compares that rhetoric and those policies to current welfare proposals to argue that "most Americans ahways wanted poor single mothers to be working in the paid labor force rather than being supported by relief").

168. Cf. Dorothy E. Roberts, The Value of Black Mothers' Work, 26 CONN. L. REV. 871, 873-74 (1994) (explaining how current welfare proposals grow out of the devaluation of Black mothering and the invisibility of the injury to Black mothers and their children when they are forcibly separated).

169. Cf. 1953 Hearings, supra note 160, at 56 (statement of David L. Perlman on behalf of the Office Employees International Union, A. F. of L.) (speaking on behalf of the child-care expense deduction that would benefit a substantial portion of the Union's members who were waged working mothers but also urging based on his "personal belief" that the amount deducted should be limited); id. at 62 (statement of Nancy M. Henderson) (referring to herself as a housewife and working mother in a professional position and arguing against the $\$ 6,000$ income limitation but further testifying that "it is perfectly legitimate to keep in the limitation on the maid salaries of $\$ 40$ per week as the maximum expenditures which could be deducted."); id. at 71 (statement of American Federation of Labor) (expressing the group's sympathy to the problem, noting that the "[v]arious bills introduced would serve to benefit women in middle- and upper-income categories, while providing little benefit to the greater majority of working mothers in the low-income groups" and raising concerns that the bills "would permit wholesale evasion and abuse and would be very difficult to enforce," and 
Interest in childcare reemerged in the late 1950s and early 1960s based on a convergence of conflicting concerns. Those concerns included the following: the lack of quality childcare provided to children with waged working mothers, articulated most strongly by the Children's Bureau; working women's need for childcare, articulated most strongly by the Women's Bureau; and a need to reduce the cost of welfare by making it possible for mothers with children to enter the waged work force, articulated most strongly by members of Congress who were feeling pressure about the growing welfare rolls. ${ }^{170} \mathrm{~A}$ bill introduced by Senator Jacob Javits, which had as its original purpose to fund childcare for waged working mothers, was modified to place greater emphasis on reducing the welfare rolls by getting mothers on welfare into the work force. ${ }^{171}$ Opposition to the legislation saw support for childcare as a communist plot to destroy the traditional family. The apparently irreconcilable strategies of fighting the Cold War by celebrating domesticity and by utilizing human resources in the waged work force continued to inform the debate. ${ }^{172}$ Ultimately the bill, providing funds for childcare for mothers on welfare and for waged working mothers with low incomes, was passed in $1962 .{ }^{173}$ The governmental funding of childcare in the early 1960s moved the issue out of the shadows of the private sphere, but only once it was viewed exclusively as a concern of the poor. ${ }^{174}$ For children and their

ultimately endorsing larger personal exemptions and lower tax rates); White, supra note 119 , at $854-55$ (attributing the consolidation of the white middle class to the racialization of welfare and "the impact of public programs like Social Security, which insured risks in primary sector jobs, tax subsidies for home mortgages, and the government-backed loans for college education").

170. See QuADAGNO, supra note 154, at 137-39. Mink provides a useful context for considering the politics of welfare during this time period:

The welfare politics that succeeded the New Deal . . . essentialized the choices and behaviors of welfare mothers and disputed their entitlement to social support. Mothers' pensions became discursively transformed into a "way of life" by the late 1960s, and the worth and rights of single mothers were displaced by the icon of the Black "welfare mother."

At least four policy decisions paved the way for these changes. First, the Social Security Act of 1935 created occupational and work history requirements that excluded many women from unemployment compensation and other income protection. Second, in 1939, New Dealers adopted a two-tiered approach to mothers' pensions when they folded into the survivors' insurance system the widows and children of male workers insured under the Social Security Act. Much like social security benefits for the elderly, survivors' insurance offered widows of insured men an autornatic and unsupervised income subsidy. With "the best" single mothers tracked separately into the social security system, Aid to Dependent Children became a program for the widows of uninsured men and for morally suspect mothers who were single because divorced or never married. Where widows accounted for 43 percent of the ADC case load in 1937, they accounted for only 7.7 percent by 1961 .

A third policy decision came in 1950, when the ADC formula for children's benefits was amended to include a grant for mothers. A fourth policy change developed over the course of the 1960s, when the Aid to Families with Dependent Children program was expanded and barriers to eligibility . . . and moral supervision . . . were eased. Commentators have pointed out that the relaxation of eligibility barriers coincided with an increase in the welfare "take-up" rate for women of color. It also coincided with a wildfire of popular perception that women on welfare didn't deserve it.

MINK, supra note 119, at 175 (footnotes omitted).

171. See QUADAGNO, supra note 154 , at 138 .

172. See id. at 139

173. See id. at 140

174. See id. at 141 
mothers from the middle class, childcare remained a private problem of reproductive labor to be solved through private arrangements. The domestic sphere was preserved, despite the fact that those private arrangements were supported by a federal tax deduction. It was important that the subsidy to ladylike workers was different in kind than that provided to working-class women because it allowed the lady-like worker and the working-class woman to remain distinct socially and politically.

The advent of the War on Poverty in the middle and late 1960s also refocused attention on childcare as a federal issue. ${ }^{175}$ The emphasis, under what was called the Operation Headstart program, was on child development and providing enriching experiences for poor children, especially African American children. ${ }^{176}$ Although a flurry of bills were introduced concerning childcare in the late $1960 \mathrm{~s}$, significant funding languished given the fiscal constraints of the Vietnam War and the growing lack of interest in initiating or expanding programs for the poor, especially for poor African Americans. ${ }^{177}$ Moreover, the rhetoric of the 1950s in celebration of domesticity still held sway. Although influenced in part by the antidiscrimination aspects of the Comprehensive Child Development Act passed by Congress in $1971,{ }^{178}$ Nixon justified his veto by characterizing the child-care programs as antithetical to family values. In his veto message, he stated that support for child development programs "would commit the vast moral authority of the national government to the side of communal approaches to child rearing against the family-centered approach." 179

During the late 1960s, several different women's groups were becoming politically active, but tellingly, their agendas generally did not include childcare. One exception to that was the Congress to Unite Women that called for "employment equality for women, free twenty-four-hour child-care centers, and, until such care was available, the right to deduct child-care expenses from taxable income." ${ }^{\prime 180}$ Whether women's groups ignored child-care issues in the

175. See id.

176. See id, see also White, supra note 119 , at 854 ("Although less than half of welfare recipients are African American, AFDC became identified as a 'black' program . . . . The counterfactual racist stereotypes of the lazy unmarried welfare mother with many children . . . that are statistically and experientially false-began to take hold among the white middle class public, including women."); Handler, supra note 167, at 861-62 (comparing the image of welfare families to its reality by relying on a range of statistics).

177. See QUADAGNO, supra note 154 , at 144-46. The experience with community action agencies in Operation Headstart that proved to be a social catalyst for antidiscrimination initiatives made the question of local control highly controversial. This is most obviously seen in the debates in 1971 surrounding the Comprehensive Child Development Act passed by Congress but vetoed by President Nixon. See id. at 150. In his veto message, Nixon specifically addressed the concern that the Office of Economic Opportunity would abandon its new function of research and return to its original function as an agency of social change that he described led to its losing "much public acceptance." See id. at 153.

178. S. 2007, 92 Cong., Ist Sess., 117 Cong. Rec. 45,612; see also Lance Liebman, Evaluating Child Care Legislation: Program Structures and Political Consequences, 26 HARV. J. ON LEGIS. 357, 377-79 (1989) (describing the Act).

179. QUADAGNO, supra note 154, at 151-52; see also Liebman, supra note 178, at 368 (arguing that, notwithstanding the veto, new money to finance childcare was spent "through several programs instead of one and with no comprehensive strategy or coherent rules of entitlement").

180. QUADAGNO, supra note 154 , at 148 . 
political sphere or proposed solving them through tax deductions, they did not consider how these proposals would affect child-care workers.

Lady-like workers did not see that their interests for adequate quality childcare coincided with the interests of working-class women. The failure to see the common interests was not an oversight, but was in fact necessary to maintaining their tenuous claim to respectability. As working women, albeit white and middle class, they always risked being mistaken for working-class women. The difficulty nineteenth-century ladies had of drawing boundaries within the domestic realm between themselves and their domestic workers was replayed between lady-like workers and their working-class counterparts. The difficulty was intensified because to be a lady-like worker meant, in many instances, that working-class women would cross the lady-like worker's threshold and care for her children in her home. Constructing the child-care worker as an inferior object within these private arrangements would allow the lady-like worker to assure her own superiority as a mother/worker. It is no wonder that within the arrangement it was impossible to see the child-care worker, as a mother with children of her own, who needed her or someone else's care. ${ }^{181}$

Notably Congress responded to the calls to reconsider the child-care tax deduction. In 1971, the same year that President Nixon had vetoed an act that would have provided for child development programs, Congress expanded the income tax deduction for childcare for the express purpose of creating employment opportunities in domestic work. ${ }^{182}$ The Revenue Act of 1971 was passed in response to a lagging economy marked by high unemployment and high inflation. ${ }^{183}$ Congress was interested in reducing taxes for individuals and creating tax incentives for business to encourage growth and increase the number of jobs in the economy. ${ }^{184}$ The modifications to the child-care deduction were politically attractive once conceived of as simultaneously reducing individual taxes while increasing employment. These dual goals were accomplished by permitting a deduction for expenditures for household cleaning and other reproductive labor unrelated to the provision of child-care services, even when the taxpayer already qualified for a child-care deduction, increasing the amount

181.

Given the gendered division of labour in the household, the labour of the housewife and the domestic worker are interchangeable; the domestic worker is employed to replace an absent full-time housewife; but when the domestic worker can't work, the housewife must. Given the social degradation of domestic work and the class inequality between the domestic worker and the mistress, however, their shared subordination does not often lead to solidarity. . . Rather than solidarity, shared subordination can lead to "housewife power strategies" through which "many housewives seek to maintain class and race privileges vis-à-vis their domestics." What characterizes servant-mistress relationships is deference from the worker and maternalism from the employer

Arat-Koc, supra note 56, at 43-44 (quoting Elaine B. Kaplan, I Don't Do No Windows, 10 SoJOURNER 10, 17 (Aug. 1985)).

182. See Revenue Act of $1971, \S 210$, Pub. L. No. 92-178, 85 Stat. 518-20 (current version I.R.C. §

21); S. REP. No. 92-437, at 13-14, 59-62 (1971), reprinted in 1971 U.S.C.C.A.N. 1918, 1929, 1965-68.

183. See H. R. REP. No. 92-533, at 3-4 (1971), reprinted in 1971 U.S.C.C.A.N. 1825.

184. See id. 
that could be deducted, and increasing the family-income limitations to $\$ 18,000$ at a time when the median family income was about $\$ 10,000 .{ }^{185}$ These modifications, which were introduced in the Senate and agreed upon in conference, was justified in part because

it can be expected to give a large number of individuals who are now receiving public assistance the opportunity to perform socially desirable services in jobs which are vitally needed. At the same time, it will help to remove these individuals from the welfare rolls and reduce the cost of providing public assistance. ${ }^{186}$

The implications of this tax change, which remains in effect today, are breathtaking. By government design, lady-like workers are offered incentives to hire domestic workers who are inextricably linked to the racial hierarchy through welfare. ${ }^{187}$ The predictable effect is to maintain the degradation of domestic work because Congress presumed it would be performed by women of color and to maintain the degradation of women of color because Congress presumed they were appropriate for domestic work. The tax change provides relatively contemporary evidence of the tenuous nature of the distinction between childcare services and other types of reproductive labor. To the extent that child-care

185. See S. REP. NO. $92-437$, supra note 182 , at $59-62$, reprinted in 1971 U.S.C.C.A.N. at $1965-68$ The Senate initially had proposed raising the family income limit to $\$ 12,000$ but later increased the limit to $\$ 18,000$ and that was the amount the Conference Committee endorsed. See S. CONF. REP. No. 92-553, at 42 (1971).

186. S. REP. No. 92-437, supra note 182, at 14 (1971), neprinted in 1971 U.S.C.C.A.N. at 1929.

187. The welfare/domestic work linkage appears to be uninterrupted not only in govemment policy but in critiques of that policy. Martha Minow, a law professor who is renowned for her work on women's and children's rights, persuasively argues in an article, Welfare of Single Mothers and Their Children, that we have a responsibility to challenge "public polices [that] seem to work chiefly to express and perpetuate negative images of a class of people" and suggests a "strict social, if not legal, scrutiny, for social policies such as the welfare work requirements applied to mothers of young children, because such policies use and sharpen the already troubling divisions of class, gender, and race." Martha Minow, The Welfare of Single Mothers and Their Children, 26 CONN. L. REV. 817, 839 (1994). She, as I do here in this article, writes about the parallels between the late nineteenth century and the late twentieth century concerning the middle-class family and uses that history to raise concerns about a policy that "is impoverished by . . narrow degrees of empathy," resulting in "a truncated sense of obligation or connection across the society." Id. at 840 . Based on this analysis she urges us to "consider some imaginative changes." It is in her proposed changes that the welfare/domestic worker linkage appears to be unbroken. She proposes "serious efforts to create jobs" and asks "Why not pay poor mothers to become childcare providers, parent aides in the schools, and home visitors supporting other neighborhood families? Why not pay poor mothers, poor fathers, and poor teens to develop community programs like athletics and gardening?' Id at 841 . Nowhere in her analysis or her proposals does she acknowledge either the "connection across the society" reflected in the waged work of childcare (i.e., the caring of children of middle-class families by working-class women) or the gender and racial hierarchies historically embedded in domestic work. Professor Minow's work shows the strength of the linkage and that the tools needed to break it have yet to be designed. Cf. White, supra note 119 , at 855 (writing about middleclass white women "[s]peaking in alliance with poor single mothers" and "insist[ing] that the world of work be made safe for women with children, by paying all women a living wage, giving all women safe, dignified, fulfilling work settings and work experiences, and restructuring work schedules and expectations so that those arrangements are consistent with the responsibilities of raising children," but failing to acknowledge that the lives of middle-class white women and "poor single mothers" are not parallel in our society but interconnected and that one way they are interconnected is that middle-class white women are some of the employers of some of the "poor single mothers" and as their employers do not have uncontested common interests). 
workers historically have enjoyed higher status than housecleaners and laundresses, this tax change shows the fluidity of the stratification and how it is infused with class, gender, and race prejudice. ${ }^{188}$

\section{Contemporary "Solutions" to Providing Childcare for Middle-Class Families}

Although statistics reveal significant progress in removing discriminatory barriers to employment for women of color, in light of current policymaking, it is not surprising that domestic work largely retains its gendered and racial cast. Class, gender, and racial hierarchies that influence our views of motherhood, childcare, and child-care workers explain how it is possible that the need for quality, affordable childcare remains high while at the same time many childcare workers work for low pay under bad working conditions. The answer is not that childcare is impervious to the rules of supply and demand. It is that the child-care market is largely determined by class, gender, and racial hierarchies, and those hierarchies determine what types of childcare are demanded and how it is supplied.

The standard by which all childcare is still measured in the 1990s is the private care and nurturing provided by the lady - the white, middle-class mother and homemaker. By this standard, the closer childcare acquired through marketplace transactions mimics childcare acquired inside the middle-class home by non-waged labor, the more attractive it is to the consumer. ${ }^{189}$ This insight suggests that what has been called the ideology of privatized childcare has two aspects: One is structural in which the government and employers leave workers to arrange childcare through private market and non-market transactions, and the other is the nature of the child-care arrangement itself. ${ }^{190}$

In the late 1980s, over half of all children under the age of five did not have waged working mothers and seventy-five percent of all children were in parental or relative care. ${ }^{191}$ Data available for the early 1990 s show an increase in the

188. See supra notes 36-37 and accompanying text (discussing the relative status of different classes of domestic workers). For an extensive description of the evolution of the tax treatment of employment-related child-care expenditures from 1954 until today, see Nantell, supra note 11, at 910-19.

189. See Abigail B. Bakan \& Daiva K. Stasiulis, Making the Match: Domestic Placement Agencies and the Racialization of Women's Household Work, 20 SIGNS 303, 308 (1995) ("[I]n recent years an ideological argument characteristic of a general backlash against feminism and women's rights has tended to discredit public child care, despite there being no basis in fact to the claim that public child care risks the emotional or physical development of healthy children.").

190. See Colen, supra note 34 , at 81 .

191. See Rector, supra note 147, at 526-27; see also JULIA WRIGLEY, OTHER PEOPLE's CHILDREN 1-2 (1995) (discussing stigmatization of day-care centers). Robert Rector reports on a survey providing data supporting the domesticity ideal:

[E]ighty percent of mothers state that they would prefer to stay at home with their own children if they could afford to do so. And by a ratio of two to one, mothers under age forty-four state that they do not regard the increased enrollment of young children in day care centers in recent years as a positive development. Rector, supra 147, at 520 (footnotes omitted). 
number of children cared for in organized child-care facilities, ${ }^{192}$ but the data also shows that in 1993 forty percent of the children under the age of five with a waged working mother were cared for by a parent, grandparent, or other relative in their own home or in the home of a relative. ${ }^{193}$ The domesticity ideal appears to be alive and well.

These statistics also reveal another way by which the domesticity ideal, combined with the gender stratification of the labor market in general, affects the demand for and cost of childcare. The decision for parents (overwhelmingly mothers) not to enter the labor force, but to remain home to care for their children, is based in part on a comparison of the cost of purchasing childcare and lost wages. Women's average wages are consistently and significantly below the average wages earned by white men. ${ }^{194}$ This wage stratification itself encourages women to remain in their homes to do the unwaged childcare. This decision is also based upon the assumptions about what is the standard of good mothering. The combination of gender wage discrimination and the domesticity ideal has the effect of suppressing the demand for waged childcare and thereby suppressing compensation of workers providing child-care services. The low wages for child-care services in turn suppress the compensation for other women in other occupational categories, which reinforces the low wages earned by child-care workers.

Both the influence of the domesticity ideal of the stay-at-home-mom and its economic viability have predictable race and class implications. One implication is that the father's salary is likely to be affected by the racial stratification of wages in the labor market. Given the higher the salaries of the father the more feasible the decision of a mother to stay at home without the benefit of money wages, the racial stratification of the labor market affects which mothers stay home and which must find waged work. ${ }^{195}$ Data show that more married African American women participate in waged labor than married white women. ${ }^{196}$ They

192. See Hemi I. Hartmann \& DIANa M. PEarce, High SkIIL and low Pay: THE Economics of CHILD CARE WORK 3 (1989) (reporting the results of a survey conducted in 1984-1985 indicating that of the 8 million children under the age of 5 who had waged working mothers, only about $25 \%$ of them were cared for in organized child-care facilities); Colen, supra note 34, at 81-82 (reporting Census Bureau data for 1987). Sharon Nantell, relying on Census Bureau data, reports that until 1991, "the primary child care arrangement for working mothers with children under the age of 5 had consistently been care in the home of another (with such care provided by a grandparent, another relative or a nonrelative)." Nantell, supra note 11, at 899 . The percentage ranged from $40.7 \%$ in 1977 to $36.8 \%$ in 1988 . See id. In 1991, care provided in the child's home was more prevalent (35.7\%). See id. Between 1991 and 1993, however, statistics show a steady increase in the use of organized facilities and a steady decline of care in the child's home. See id. at 900 (for children less than I year old, in $1991,12 \%$ were cared for in organized facilities as compared to $19 \%$ in 1993; for children $3-4$ years of age, the percentage increased from $33 \%$ in 1991 to $39 \%$ in 1993).

193. See Nantell, supra note 11 , at 898.

194. See U.S. DEP'T OF LABOR, BUREAU OF LABOR STATISTICS, EMPLOYMENT AND EARNINGS, tbl. 37, at 204 (1997) (median weekly eamings for men in 1996 was \$599 compared with women's of \$444).

195. See supra notes 146-47 and accompanying text (referring to data showing the relative incomes of married men based on race).

196. See Dorothy Brown, The Marriage Bonus/Penalty in Black and White, in TAXING AMERICA, 45, 49 (Karen B. Brown \& Mary Louise Fellows eds., 1996) (citing U.S. COMM’N ON CIVIL RIGHTS, STAFF REPORT ON THE ECONOMC STATUS OF BLACK WOMEN: AN EXPLORATORY INVESTIGATTON 105 (1990)) (73\% of 
also show that married African American women contribute a higher percentage of income to the household than white women do. ${ }^{197}$

Another race and class implication is the role that women who hold professional and managerial positions play in the child-care labor market. ${ }^{198}$ Armed with economic wherewithal and the domesticity ideal, a significant number of these mothers hire child-care workers to work in their homes on a full-time or live-in basis. ${ }^{199}$ Reported data indicate that, as of 1993, about three percent of the children with waged working mothers are cared for by a child-care worker who lives in the family home. ${ }^{200}$ It is estimated that as of 1993 , there were as many as one-million immigrants hired nationwide to perform childcare and other domestic work. ${ }^{201}$

Notwithstanding that live-in care remains atypical among waged working mothers, it has had a significant effect on the child-care labor market. ${ }^{202}$ With

married Black women compared to $64 \%$ of married white women were in waged labor force in 1990$)$.

197. See id., citing U.S. COMM'N ON CIVIL RIGHTS, supra note 196, at 100, table 8.6 (married Black women contributed $40 \%$ of their total household's income as compared to a $29 \%$ rate of contribution by married white women); see also Brown, supra note 146, at 1491-95 (indicating contribution of African American wives to household income at different income levels).

198. Although women of color are represented within this occupational category, a disproportionate number of white women hold these positions. See Herz \& Wootton, supra note 137, at 58 (reporting that 30\% of white women as compared to $21 \%$ of Black women and $17 \%$ of Hispanic women held managerial and professional jobs in 1994). Although few African American women are performing domestic work in homes, $28 \%$ of Hispanic women are, which is "four times their share of total employment." Id. at 59-60.

199. See Colen, supra note 34, at 82. See also Arat-Koc, supra note 56, at 33, 35 ("[E]mployment of live-in domestic workers, a long-abandoned practice in North America, is once again being presented as a solution to the burdens of housework and childcare among high and middle income groups;" because middleclass families in Canada cannot get subsidies for childcare, "parents with two or more pre-school children [find] employment of a live-in nanny would cost significantly less than sending children to a day care centre or hiring live-out help."). El.

200. See Nancy Imperiale, Child Care with Foreign Flair, ORLANDo SENTINEL TRIB., Feb. 23, 1993, at

201. See Lynn Smith \& Chris Kraul, Together in the Shadows of the Law: The Link Between Panents and Nannies who are Illegal Immigrants Creates an Uneasy and Delicate Balance of Power, Love, Need and Suspicion, L.A. TMMES, Jan. 28, 1993, at A1, A24; see also ROMERO, supra note 36, at 86-87 (describing how migrant women are over-represented among private household workers).

202. The employment of child-care workers who live-in or go to families' homes each day is not limited to high-income families. Newsweek reported in 1993 that

now more families at all income levels are paying sitters to work in their homes, thanks in part to the prevalence of illegal immigrants willing to work at low wages. During one recent survey, ... [a] copresident of the Families and Work Institute in New York . . . says she was stunned to find how many assembly-line workers in Texas had nannies at home. . . " [T] women coming across the border . . . for in-home care." . . . In Chicago, Christine Thomton Wiener of Nannies Midwest, Ltd., estimates that undocumented workers account for 60 to 70 percent of the nanny market in her area.

Melinda Beck et al., The Parent Trap, NEwswEEK, Feb. 1, 1993, at 34-35. See ROMERO, supra note 36, at 9192 (describing a 1983 special report published in an El Paso newspaper that concluded "there may well be more maids per home in the city than anywhere else in the nation. . . At $\$ 40$ plus room and board a week, many El Pasoans can afford them, not just the rich"); see generally Vicki L. Ruiz, By the Day or Week: Mexicana Domestic Workers in El Paso, in To TOL THE LIVELONG DAY, supra note 55, at 269 (exploring the demographic, economic, and historical context affecting women living in the border town of Ciudad Juárez, Mexico and working in El Paso, Texas). But see Leslie Eaton, Show Nanny the Money: As Economy Booms, Pay Rises for Child-Care Workers, N.Y. TIMES, July 26, 1998, at 27 (reporting that "millionaires" are paying college educated maternity nurses and nannies up to $\$ 1000$ a week after taxes and providing health insurance, a retirement benefit, and in some cases even buying the child-care worker a luxury car) 
live-in care viewed as the best form of care because it comes closest to reproducing the ideal of middle-class parenting (mothering), the exploitative working conditions of live-in child-care workers has the further effect of depressing compensation throughout the child-care labor market. The expectations of prospective parent-employers regarding market wages, working conditions, and the general view of the economic worth of the service are greatly influenced by the market reality that undocumented migrant women of color are available to mimic unwaged, home childcare for low pay. ${ }^{203}$

Through live-in childcare, the lady-like worker has found a way to maintain respectability and thereby mark a boundary between herself and her family and other waged working mothers and their families. She has done it by modifying, while at the same time perpetuating, the historical meanings of domestic work, gender, and race. ${ }^{204}$ In the nineteenth century, the lady adopted practices that maintained her hold on respectability by separating herself from the waged worker with whom she shared her home; in the twentieth century, the lady-like worker maintains her respectability in the home and in the marketplace by adopting practices that separate herself from the waged worker she leaves in her home while she enters the marketplace. ${ }^{205}$

Workers view live-in jobs requiring both housework and childcare to be the worst type of waged reproductive labor. ${ }^{206}$ Generally only women who cannot

203. See Demetrios G. Papademetriou, The 'Zoë Baird Problem' Is a Flawed Labor Policy, N.J. L.J., Feb. 15, 1993, at 17; ROMERO, supra note 36, at 92 ("Native-born domestic workers are unable to raise wages or improve working conditions as long as employers have access to a virtually inexhaustible reserve army of undocumented women.").

204.

[T] The very spheres from which the foreign domestic worker is excluded also need her in order to function in their present form, both materially and ideologically. . . [T]he dominant society suppresses awareness of its dependence on foreign domestic workers by rendering domestic workers socially invisible within the household and legally invisible within immigration and employment protection legislation.

Audrey Macklin, Foreign Domestic Worker: Surrogate Housewife or Mail Onder Servant?, 37 MCGLL, L.J. 682, 686 (1992); see Colen, supra note 34, at 90, $92-97$ (reporting how West Indies migrant child-care workers in New York City in the late 1980s experienced their employers' "humiliating behavior" that frequently made them feel invisible and how employers' "profound dependence on caregivers" influenced the qualities they sought in a caregiver and their stereotypical assumptions about them); Macklin, supra, at 751 ("The grim truth is that some Canadian women's access to the high paying, high status professions is facilitated through the revival of semi-indentured servitude. Put another way, one woman is exercising class and citizenship privilege to buy her way out of sex oppression.").

205. See Macklin, supra note 204, at $749-50$ (comparing current trends in reproductive labor in which middle- and upper-class women hire household workers with pre-industrial mistress/domestic worker relationships).

206. See Colen, supra note 34, at 80-81; Doreen Carvajal, For Immigrant Maids, Not a Job but Servitude, N.Y. TMES, Feb. 25,1996 , § 1, at 1,38 ; see also ROMERO, supra note 36 , at 12-13, 66-67 (describing results of a study of Chicana domestic workers in Denver in which the women in day work (note not live-in) found that the flexibility of their employment supported their family and community identities and provided them a measure of autonomy); Abigail B. Bakan \& Daiva Stasiulis, Foreign Domestic Worker Policy in Canada and the Social Boundaries of Modern Citizenship, 58 SCI. \& SOC'Y 7, 16, 16 n.10 (1994) (referring to a survey of live-in workers in Toronto indicating that $65 \%$ of the household workers surveyed worked more than 44 hours per week and $44 \%$ of them reported that they had received no compensation for performing overtime work and reasoning that "[e]xploitation of live-in domestic workers may arise almost invisibly, as there is an inherent expectation of the offer of 'sacrifices' associated with 'family ideology"'). 
otherwise find alternative employment within waged reproductive labor take these positions. ${ }^{207}$ That means they are left to those women most desperate for employment to support themselves and their families. ${ }^{208}$ Through ironic twists of logic, it is the women's attempt to escape from poverty in their home countries that becomes a reason for U.S. families to pay exploitative wages and impose exploitative working conditions. ${ }^{209}$ The wages paid may compare favorably to the wages the women would receive in their home country, and that fact becomes a ready justification by child-care consumers for the employment terms they impose on child-care workers. ${ }^{210}$ It is not difficult to conclude that these justifications have persuasive power because they are made through a racial prism.

The child-care employment practices described below provide further support for the contention that the pay and working conditions are race-based. ${ }^{211}$ Reports

207. See generally Rina Cohen, Women of Color in White Households: Coping Strategies of Live-in Domestic Workers, 14 QUALTTATIVE SOC. 197 (1991) (outlining various strategies the household workers use to limit the overreaching of employers and make a life for themselves based on interviews of live-in household workers who migrated predominantly from Third World countries).

208. See Colen, supra note 34 , at 82 (describing specifically the waged reproductive labor market in New York City during the 1980s).

209. See Carvajal, supra note 206, at 37 ("The dirty little secrets behind the closed doors of some upper middle class houses in the suburbs from New York to Los Angeles are the immigrant women who work up to 15-hour shifts, six day a week, for wages amounting to $\$ 2$ an hour.").

210. But see Macklin, supra note 204, at 690 (discussing postwar immigration policies in Canada regarding household workers and indicating that, because the "Caribbean governments . . . were anxious to make a good name for their citizens abroad, their selection process gave priority to educational attainment and ambition over domestic skills," resulting in "[m]any candidates [who] were actually nurses, teachers or civil servants in search of better job opportunities in Canada").

211. See Bakan \& Stasiulis, supra note 189, at 315 ("Migration and paid domestic service are thus elements of a global set of linkages in which gendered and racialized ideologies play a significant part."); see also WRIGLEY, supra note 191, at 10-11 (providing examples of how parents rely on national and cultural prejudices in choosing a household worker, for example preferring Salvadoran women over women from Guatemala)

Yet, further evidence of the racialized hierarchy related to live-in care in the United States is the phenomenon of the "secondary arrangement," meaning that a child is provided care through more than one child-care arrangement. One example of this is supplementing live-in care by enrolling the child in a preschool. One study shows that when primary care is provided in the child's home, a secondary arrangement is more likely to be used. See Todd P. Steen, An Analysis of Secondary Child Care Arrangements, AM. ECONOMIST, Spring 1994, at 82, 88-89. It further shows that whites are more likely to use such arrangements and that women with higher wages have a higher propensity to use secondary care. See id. at 89; see also Colen, supra note 34, at 94-95 (reporting that the secondary arrangement occurred in a number of the households studied in New York City when parents hired West Indian women as live-in or full-time caregivers). Anecdotal reports reinforce the findings of the Steen study and reveal the stratification of reproductive labor and its racial component. For example, one report described a mother who placed advertisements in newspapers throughout the country, "including a local Korean newspaper and a Middle Westem daily-that yielded the 50-year-old Mexican woman who cares for the house and the children. [She] also sends her 3-year-old to a day-care school so he has a chance to socialize with others his age." Elsa Brenner, Coping with Uncertainties in Child Care, N.Y. TIMES, April 25, 1993, § 13WC, at 1, 8. Another mother, an attomey in Texas whose husband is also an attorney, pays "two illegal domestic workers-one lives in, one lives out $-\$ 130$ a week each in cash to help with their household and three young children. With their combined six-figure income, that doesn't sound like much, but [the mother] says it adds up, particularly since they are paying \$1,000 a month in preschool tuition." Beck et al., supra note 202, at 35 . These two stories suggest that childcare continues to be stratified along race lines where the "dirty work" for low pay remains associated with women of color. The enhancement of live-in childcare through preschool programs has the effect of maintaining the inferior status and working conditions of the live-in household worker. Rather than using the available resources to increase her wages and benefits 
by immigrant rights advocates that the "miserable workplace conditions are rampant" have a racial cast. ${ }^{212}$ One advocate repeats the story told to her of a twenty-seven-year-old woman who was in the country illegally from Mexico:

Once, she said, she was thrown out of a Malibu home at 5 a.m. for refusing to get up to see to a crying infant, a duty she never agreed to or was being paid for. She watched the owners of a Long Beach home let dogs into the kitchen she had just cleaned, feeding them food scraps on the floor.

She said she missed countless outings with her friends during off hours when her Huntington Beach employers called at the last moment to say they were running late and asked if she could stay over an hour or so even though [she] had worked her full 12-hour day. She quit after the couple made her pay for a broken plate. ${ }^{213}$

In the early 1990s, "[w]ithout English or legal papers, the domestic workers earned as little as $\$ 65$ a week in San Diego; with English and papers they earned as much as $\$ 500$ in Los Angeles."214 An employee who lives in the household, but who is without necessary immigration documents, may be paid less than

and improve her working conditions, the family chooses to provide other services to the child.

212. Smith \& Kraul, supra note 201, at A24. Julia Wrigley expands upon the relationship of working conditions to race when she reports that

[p]arents who hire high-status employees are not always confident they can control them. They may hesitate to issue orders to an educated woman the way they would to a less-educated immigrant. The head of a Manhattan domestic employment agency said this was a factor in her failure to find a job for a twenty-seven-year-old American woman.

WRIGLEY, supra note 191, at 5. For a further discussion of the nature of the exploitative working conditions, see Arat-Koc, supra note 56, at 39-43 (addressing the problem for live-in workers of having no separation between home and work and how that can lead to employers exploiting their employees; also describing the inadequacy of laws protecting domestic workers in Canada and the failure of governments to enforce them); Bakan \& Stasiulis, supra note 206, at 17 (describing sexual, physical, and emotional abuse and racial harassment); Diana Vellos, Immigrant Latina Domestic Workers and Sexual Harassment, 5 J. GENDER \& L. 407, 418-26 (1997) (describing low wages and hostile working conditions, particularly sexual harassment, experienced by undocumented Latina domestic workers in the United States).

213. Smith \& Kraul, supra note 201, at A25. In contrast to the treatment described in the text, the au pair program operated through the U.S. Information Agency (USIA) provides substantial protections to the child-care worker. For example, the USIA finalized new rules effective September 5, 1997, which among other things, clarifies that au pair participants must receive the federal minimum wage and specifies that an au pair may not provide more than ten hours of childcare on any given day or more than 45 hours of childcare in any given week. See Exchange Visitor Program (Au pairs), 62 Fed. Reg. 46,876 (1997) (to be codified at 22 C.F.R. 514.31) (finalizing amendments to existing regulations the interim final rule, 62 Fed. Reg. 34,632 (1997)). Until 1995, when Congress passed the Au Pair Program Extension, Pub. L. No.104-72, 109 Stat. 776 (1995), the USIA was limited to authorizing agencies to bringing young people, typically women, only from Western and Northern European countries. See WRIGLEY, supra note 191, at 51-52; Papademetriou, supra note 203 , at 28 . This program is structured to reduce, if not eliminate, the domestic service nature of the employment relationship by requiring that parents provide au pairs their own room, board, and access to transportation and treat the au pair (which is French meaning as an equal) as a family member. See Imperiale, supra note 200, at E1; Robert J. Klein, Finding Live-in Help for your Child that is Loving, Loyal and Also Legal, MONEY, Sept. 1989, at 155, 155. That the workers in this program to date have been nearly exclusively European means that it has served to reinforce the racial stratification of child-care service rather than disrupt it.

214. Smith \& Kraul, supra note 201, at A24. 
what the family would have to pay a child-care center. In 1993, in Houston, the current average for a live-in nanny was $\$ 125$ per week as compared to $\$ 200$ at a child-care center. ${ }^{215}$

A live-in household worker, of course, does not inevitably experience abusive working conditions. It is the isolation of live-in work and the unstable immigration status of household workers that increase the potential for abuse. The structure of the employment arrangement, along with "the racism that deepens and provides additional legitimation" for exploitative conduct, makes it difficult for a household worker to protect herself from exploitative employers. ${ }^{216}$ Given the history of waged childcare, what we know is that this potentially exploitative employment arrangement is built on class, gender, and racial hierarchies. What we also know is that the structure of the arrangement maintains the distinction between the lady, the lady-like worker, and the working-class woman.

What we must not ignore is the complicity of the United States and other developed countries in having created the economic conditions in the women's home countries in recent decades that lead them to seek and remain in live-in household work away from their children, other family members, and native country. ${ }^{217}$ Their migration is one of the "legac[ies] of imperialism" that "combine[] with modern conditions of indebtedness."218 When the women's home countries adopt structural adjustment policies demanded by the International Monetary Fund and the World Bank that result in severe reductions in social services while emphasizing export commodities over local market expansion, a source of migrant female labor is produced. ${ }^{219}$ The government of the home country has reasons to encourage the migration because it is a solution to the problem of chronic unemployment, and it becomes a source of hard

215. See Jo Ann Zuniga \& Pamela Yip, Hiring of Illegal Aliens for Child Care Is Common, Hous. CHRON., Jan. 22, 1993, at A13; see also Bakan \& Stasiulis, supra note 206, at 25 ("[T] he most significant sources for the racial/ethnic variations in the degree of exploitation experienced by foreign domestics reside not in the allocative and legitimizing role of racial/gender stereotypes, but rather in the different citizenship statuses and motivations of white/European women and third-world women of color. . . . The threat of deportation to an advanced capitalist European country does not hold the same implications as it does to a poor third-world country."); id. at 11-19 (analyzing Canadian immigration policies regarding household workers during the twentieth century and showing their racial character and the relationship of race to issues of citizenship); Macklin, supra note 204, at $687-92$ (same).

216. Bakan \& Stasiulis, supra note 206, at 17-18, 24 (making these points in reference to Canadian immigration laws and employment practices).

217. Avoiding this complicity can lead to statements, such as those statements found in $M$. Isabel Medina, In Search of Quality Childcare: Closing the Immigration Gate to Childcare Workers, 8 GEO. IMMGGR. L.J. 161, 199 (1994) that "[p]ersons from overseas are willing and are sometimes more able to perform childcare work. It is unconscionable that parents in our society are denied access to these willing and able childcare providers because they are placed at the bottom of the waiting list for immigrant visas." $I d$.

218. Bakan \& Stasiulis, supra note 189 , at 315.

219. See CyNthIa Enloe, Bananas, Beaches \& Bases: Making Feminist SENSE of INTERnational PoLmics 185 (1989); Bakan \& Stasiulis, supra note 189, at 315; Colen, supra note 34, at 79-80; Macklin, supra note 204, at 694-96; see also Dan Gatmaytan, Death and the Maid: Work, Violence, and the Filipina in the International Labor Market, 20 HARV. WOMEN's L.J. 229, 237-38 (1997) (describing the Philippine government's policy of encouraging the export of labor as a means of servicing and repaying the country's debt). 
currency when the women send back a portion of their pay to support their children and other family members. ${ }^{220}$ The U.S. government also welcomes the migration because it assists the economies of debtor, underdeveloped nations, does not impose substantial burdens on state- or federally-funded social services because the women usually are forced to migrate without their families, suppresses child-care wages that the federal government pays directly or indirectly through its welfare and tax programs, and reduces a labor shortage in child-care workers. ${ }^{221}$ Many of these benefits, of course, depend on the women crossing the U.S. borders without its formal blessing of legal immigration. ${ }^{222}$

Although much work has been done by various grassroots organizations to expose these labor issues and the media has reported some of the egregious working conditions, the basic structures supporting the exploitative employment remain unchanged. ${ }^{223}$ Abigail Bakan and Daiva Stasiulis, experts in the field of domestic work and immigration, argue

[t] he perpetuity of the exploitative conditions associated with in-home domestic service has meant that a practice .. . has become institutionalized in conditions of advanced capitalist liberal democracies. This unequal assignment of rights that works through constructed notions of immigrant status, race, gender, and class is now commonplace in the citizenship practices of most advanced capitalist states. ${ }^{224}$

220. See Bakan \& Stasiulis, supra note 206, at 13 (indicating that the governments of Caribbean countries did not challenge Canada's harsh and unequal treatment of Caribbean household workers who migrated there because the migration alleviated the chronic unemployment being experienced in those countries).

221. Cf. Arat-Koc, supra note 56, at 45-51. Sedef Arat-Koc describes Canadian immigration policies during the postwar period designed to assure a supply of household workers without citizenship rights, concluding:

[t]he state plays an active role in structuring and controlling not only the volume but also the conditions of these workers. There is a striking contrast between the laissez faire approach the liberal state has taken, which favours private solutions to problems in the domestic sphere, and its rigid intervention in the provision, organization and control of 'help' for that sphere

Id. at 51; see also Medina, supra note 217, at 170-86 (describing the Immigration Reform and Control Act of 1986 (IRCA), which enacted sanctions against employers hiring undocumented migrant workers, and concluding that this attempt to protect U.S. borders and stem the exploitation of workers has been ineffective; describing the Immigration Act of 1990, which increased the available number of employment-based visas but classified child-care workers as unskilled and severely limited the number of visas available for unskilled workers, and concluding that the 1990 Act "effectively closed the door to childcare visa applicants").

222. See Macklin, supra note 204, at 685 (providing a useful framework for considering the migrant household worker based on an insider/outsider dichotomy that "encompass[es] a variety of situations where a person is simultaneously part and not part of a social structure in which she finds herself" and reasoning that "[i]n these settings, being an outsider means not only exclusion from participation, but also denial of the protections normally accorded to insiders").

223. See Beck et al., supra note 202, at 36-37; Carvajal, supra note 206, at 1, 38; Macklin, supra note 204, at 738-39; Smith \& Kraul, supra note 201, at A24-25; Zuniga \& Yip, supra note 215, at A13. But see Bakan \& Stasiulis, supra note 206, at 18-19 (describing successful efforts in the 1970s of grassroots organizations to change the immigration laws in Canada while acknowledging that the changes had not "represented an unqualified gain" and that other changes in 1990 in the law, which were widely criticized by advocacy groups representing household workers, had a particularly racist cast).

224. Bakan \& Stasiulis, supra note 189 , at 332 
The use of undocumented migrant women to solve an array of problems for the home and host countries and for middle-class families is tolerable because it takes place in the long history of the degradation of domestic work and the women of color who perform it. ${ }^{225}$ The circumstances of the child-care worker and the child-care consumer, of course, have changed from the late 1800 s to the late 1900s. Although the meaning of domesticity, motherhood, and respectability changes from one period to the next and from one locality to another, contemporary arrangements of waged childcare continue to sustain class, gender, and racial hierarchies.

\section{Summary of the History of Waged Childcare}

The U.S. history of domestic work and, in particular, of waged childcare teaches us two important lessons for applying the antisubordination principle when evaluating the tax law's treatment of employment-related child-care expenditures. The first is that systems of subordination do not operate independently from each other. On the contrary, although each form of subordination operates in a particularized way in different localities at different time periods, they each reinforce and support the other. The racial division of domestic work depends on the gendered nature of reproductive labor and both operate to support the construction of the working class as inferior. As Sedef Arat-Koc writes, "[r]ather than solving the problem of gender inequality, . . . [domestic work] adds class and racial dimensions to it[;] . . [r]ather than easing the public/private split in society, ... [the domestic work] solution polarizes and deepens it, with added class and racial dimensions."226

The second lesson is that wages and working conditions for child-care workers are not products of a free competitive market establishing an equilibrium between supply and demand. The labor history, instead, shows how social prejudices and government intervention greatly influence those wages and working conditions. For our purposes, what follows from the history of the childcare labor market is that a tax analysis of employment-related child-care expenditures must include consideration of the structures in the market that support economic exploitation of child-care workers. Looking at the purchasing

225 .

Gatekeepers to citizenship serve to regulate the entry into and exit from nation-states and labor markets as well as access to citizenship rights. All gatekeepers accomplish this work in part through the construction, articulation, and reproduction of stereotypes about who is, or is not, an appropriate candidate for citizenship within a given nation-state. . .

[I]t is suggested that differences in citizenship status that reflect the hegemony of advanced capitalist states also interact with racial/ethnic, gender, and class differences. These socially constructed differences facilitate structural inequities between predominantly white female citizens and predominantly noncitizen women of color.

Id. at 317, 331 ; see also MICHAEL WALZER, SPHERES OF JUSTICE: A DEFENSE OF PLURALISM AND EQUALITY 56-61 (1983) (analyzing the advantages to wealthy European host countries and the costs to their "guest workers" of being denied citizenship rights).

226. Arat-Koc, supra note 56 , at 53 . 
of child-care services as an objective fact, unrelated to the political and economic strongholds of power that influence the nature of that transaction, becomes a wholly inadequate starting point of analysis.

\section{EMPLOYMENT-RELATED CHILD-CARE EXPENDITURES AND TRADITIONAL TAX PRINCIPLES: THE MYTH OF OBJECTIVITY}

Part II showed how linking reproductive labor to the private sphere and making the domestic worker invisible served the interests of the middle class and therefore was necessarily based on class, gender, and race subordination. The purpose of Part III is to identify how traditional tax principles maintain those subordinating systems. There are two conventional tax concepts that are central to analyzing child-care expenditures incurred by a wage earner. One is the business/personal distinction, and the other is imputed income. The preceding historical analysis is used to show how each, as understood within traditional tax analysis, tends to reinforce dominant structures and how both, once subjected to an antisubordination analysis, could be applied to determine the appropriate tax treatment of child-care expenditures.

\section{A. The Business/Personal Distinction}

The business/personal distinction arises out of the widely accepted understanding of what should constitute income under an ideal accretion tax system. ${ }^{227}$ The ideal tax base was first developed by Robert Haig and then refined by Henry Simons, and is defined to be the sum of "(1) the market value of rights exercised in consumption and (2) the change in value of the store of property rights between the beginning and end of the period in question."228 Simons recognized that this definition of a comprehensive income tax base requires "distinguishing between consumption [personal] and expense [business]. ${ }^{.229} \mathrm{~A}$ business expense is to be taken into account as a diminution in the second part of the calculation when determining the change in value of accumulations. $X$ dollars expended, for example, for inventory, which is later sold for $Y$ dollars would result in $Y-X$ income being subject to tax during the

227. Compare, e.g., I.R.C. $\S 162$ (allows deduction for "all the ordinary and necessary expenses ... in carrying on any trade or business") with I.R.C. $\$ 262$ (disallows deduction for "personal, living, or family expenses"); see DAVID F. BRADFORD, UNTANGLING THE INCOME TAX 16-20 (1986).

228. The definition of income in an ideal accretion tax system was first stated by Robert Haig "as the money value of the net accretion to one's economic power between two points in time." Robert M. Haig, The Concept of Income-Economic and Legal Aspects, in THE FEDERAL INCOME TAX 1, 7 (Robert M. Haig ed., 1921). It was later refined by Henry Simons. SiMONS, supra note 13, at 50.

Jennifer Brooks encourages us to be critical of relying on the Haig-Simons definition of income because, "[e]ven the most widely approved theory of income may be found faulty in succeeding generations." Jennifer J.S. Brooks, Taxation in Human Capital, in TAXING AMERICA, supra note 196, at 58, 61. I see the introduction of the antisubordination principle as consistent with her concern that the dominance of the Haig-Simons definition has precluded consideration of the social context in which the income tax operates. See id. at 64-65.

229. SimONS, supra note 13 , at 54 . 
period. In contrast, $X$ dollars spent during the taxable period for comfort or pleasure, such as for a candy bar or going to a movie, represent an amount to be taken into account as an increase in the first part of the calculation. ${ }^{230}$ The expenditure for candy or a movie is treated as producing no increase in the taxpayer's store of property rights. The conclusion that the expenditure does not produce increases in wealth means that it is treated, under part one of the calculation, as an amount used for consumption and subject to taxation for the taxable period. ${ }^{231}$ The ideal income definition, therefore, requires that every expenditure be classified as either personal, which means that it should not be taken into account as a reduction of income either now or later, or business, which means that it should be deducted from income either now or later. ${ }^{232}$

One difficulty, of course, is that an inherent problem with Simons's definition that he himself recognized is that "[a] thoroughly precise and objective distinction [between personal and business] is inconceivable." ${ }^{3233}$ Simons saw the problem exclusively as a problem of inadequate information. He believed that the difficulty with the distinction was that it required determination of subjective intent. ${ }^{234}$ Child-care expenditures provide an excellent example of how difficult the distinction proves to be for Simons. As he saw the problem with making his definition operational for an issue like child-care expenditures, it was necessary to determine whether taxpayers go to work for the purpose of earning sufficient

230. A more complete description of the tax treatment of a personal expenditure would recognize that the $\mathrm{X}$ dollars spent were first eamed and treated as an increase in accumulations for the period in accordance with the second part of the calculation. Once expended for consumption purposes, the amount of accumulations is reduced by $X$ dollars while the amount of consumption is increased by the same amount. The net effect of both explanations is that the ideal tax base for any period remains the same regardless of whether the increase in accumulations is saved or consumed.

231. The description in the text of the treatment of the expenditure for candy or a movie and its accompanying explanation in terms of the Haig-Simons definition of income reflects conventional tax analysis. For some tax scholars, however, reconsideration of the meaning of the Haig-Simons ideal tax base, especially how it has been used to support current tax treatment of human capital, is overdue. See, e.g., Brooks, supra note 228, at 75-76 (demonstrating how the definition of human capital is over-inclusive with the effect that "[v]alues commonly associated with human capital may in fact be additional, untaxed values attached to material capital"); Charlotte Crane, Shifting from an Income Tax to a Consumption Tax: Effects on Expenditures for Education, in TAXING AMERICA, supra note 196, at 146, 155 (examining the various presumptions made to make the income tax operational and concluding that "[t]he presumptions made regarding the transfer of values concerning the development of human potential are among the least satisfactory of any of those adopted by the income tax"); Gwen Thayer Handelman, Acknowledging Workers in Definitions of Consumption and Investment: The Case of Health Care, in TAXING AMERICA, supra note 196, at 119, 134 (showing that the Haig-Simons model does not specify the proper tax treatment of expenditures related to human capital and urging a tax analysis that does not "disregard the lifelong investments for income production in ourselves and our children").

232. But see Denise D. J. Roy, Consumption in Business/Investment at Home: Environmental Cleanup Costs Versus Disability Access Costs, in TAXING AMERICA, supra note 196, at 170, 182-84, 189 (arguing that, even if the tax law were to recognize better than it does now that some expenditures classified as personal have a business element and that some expenditures classified as business have a personal element, there is yet a type of non-personal business expense that represents consumption that arguably should not be deductible).

The timing of a deduction depends on the timing of the income and that requires consideration of realization rules. The realization principle is unnecessary to a discussion of employment-related child-care expenditures. For a summary of the realization principle, see MARVIN A. CHIRELSTEIN, FEDERAL INCOME TAXATION 72-74 (8th ed. 1994).

233. SIMONS, supra note 13 , at 54 .

234. See id. at 54. 
funds to purchase child-care services for their children, or whether they purchase child-care services for the purpose of earning income in the waged labor market. For Simons, child-care expenditures were troubling because they raised the "unwelcome criterion of intention," that he determined to be "inescapable."235

The difficulty of distinguishing business and personal expenditures is far more complex than merely a problem of determining taxpayer intent. The problem with the distinction is that it marks business expenses as productive, and personal expenses as unproductive in a way that misapprehends productivity in the home and nonproductivity in the marketplace. Rather than acknowledging that household cleaning, cooking, and childcare, among other reproductive tasks, are socially and economically necessary, the intense monitoring of the business/personal distinction that occurs in the tax law denies the intermediate value of reproductive tasks - a value based on how the results from reproductive labor produce further value. ${ }^{236}$ Reliance on a distinction that is "inescapably" difficult to apply has resulted in a tax analysis that distorts the reality of the uncertainty surrounding an expense classified as business or one classified as personal. The binary classification system requires a willed ignorance of the unproductive aspects of the public marketplace and the productive aspects of the private home.

The "inescapable" problems found in the ideal income tax base with the business/personal distinction are further exacerbated when considered from an antisubordination perspective. As shown in Part I, the public/private distinction, which was intensely monitored during the industrialization of the country in the nineteenth century and has continuing influence today, justifies and supports class, gender, and racial hierarchies. The public/private distinction is mirrored in the tax law's business/personal distinction. Within an antisubordination framework, the business/personal distinction, is no longer seen as an abstract tax concept disconnected from social and economic relationships. Rather, the distinction takes on a different meaning once it is understood as being the functional equivalent, in tax terms, of the public/private distinction, the production/reproduction distinction, and the cult of respectability. Reconnecting the business/personal distinction to its social roots removes its seeming

235. Id.

236. See Colen \& Sanjek, supra note 35, at 3; Richard Goode, The Economic Definition of Income, in COMPREHENSIVE INCOME TAXATION 1, 15 (Joseph A. Pechman ed, 1977). Economists have recognized some of the problems with the business/personal distinction. See DAVD F. BRADFORD \& U.S. TREASURY TAX POLICY STAFF, BLUEPRINTS FOR BASIC TAX REFORM 28 (2d ed. Rev. 1984); Goode, supra, at 1, 5-15; see also Crane, supra note 231 , at 155 (reflecting how the tax law presumes all development of human potential, which would, of course, include child care provided by a parent or a waged worker, is "consumption, rather than investment leading to taxable income" and, therefore, suggesting that child care is treated as personal not only because it is not viewed as related to the employment of the parent or parents but because it produces human potential, which itself is viewed in the tax law as personal); Handelman, supra note 231, at 120 (suggesting that embedded in the business/personal distinction is the view that productivity is linked to entrepreneurial activity rather than to the labor of the worker, raising yet another reason why employment-related child-care expenditures, which are closely associated with workers rather than entrepreneurs, are classified as personal rather than business). 
objectivity and makes the widespread willingness to tolerate its "inescapable" problems seem less benign. Even more questions are raised about the acknowledged indeterminacy of the business/personal distinction, as well as its being a proxy for the public/private distinction, when the concept of imputed income is considered.

\section{B. Imputed Income}

When taxpayers personally provide services for themselves, they are producing in-kind income that is referred to in conventional tax analysis as imputed income. ${ }^{237}$ When taxpayers use their own personal property for their own benefit, their property is producing in-kind income that is also referred to as imputed income. Both types of in-kind income are labeled as income because the services and the property produce an economic benefit to the taxpayer. Both types of in-kind income are labeled imputed because the activities take place outside of the marketplace and because the services and property are used for personal (consumption) purposes by the person producing them. The hallmark of imputed income is that the economic benefits are both produced and exhausted by the taxpayer outside the marketplace.

Non-marketplace activities generally are not the subject matter of an accretion tax as defined by Haig-Simons for three reasons. ${ }^{238}$ The first reason for its exclusion from the definition of the ideal income is that it is administratively difficult to value. ${ }^{239}$ The second reason for its exclusion is that it is viewed as inconsequential for determining taxpayers' ability to pay. Its trivial importance is based on the presumption that imputed income, most especially imputed income from services, varies "with considerable regularity, from one income class to the next, along the income scale."240 The third reason for its exclusion is that to include imputed income in the tax base would be inconsistent with American values that require limited governmental interference with an individual's private life. ${ }^{241}$ Although many policymakers might argue that, without unduly sacrificing administrative ease or individual privacy, more imputed income, especially from property, should be included in the tax base to more accurately measure each taxpayer's ability to pay, ${ }^{242}$ no one seriously argues that all imputed income could or should be included in the tax base.

237. The term in-kind income is used to indicate that the income is not received by the taxpayer in the form of cash but rather in the form of services or property use. For examples of discussions of imputed income, see WLLIAM D. ANDREWS, BASIC FEDERAL INCOME TAXATION 74 (4th ed. 1991); CHIRELSTEN, supra note 232, at 22-25; William A. KLEIN \& Joseph BanKMan, Federal InCOME TAXATION 121 (11 th ed. 1997).

238. But see I.R.C. $\$ 7872$ (regarding below-market loans of cash); CHIRELSTEIN, supra note 232, at 218-19 (discussing below-market loans of cash)

239. See KLEIN \& BANKMAN, supra note 237, at 121; see also SMONS, supra note 13, at 51-52 (demonstrating difficulty of line drawing).

240. SIMONS, supra note 13, at 53. See infra notes 271-305 and accompanying text (critiquing Simons's analysis of imputed income).

241. See, e.g., KLEIN \& BANKMAN, supra note 237 , at 121

242. See SLMONS, supra note 13 , at $110-15$. 
The definition of imputed income set forth above is narrower than that found generally in the tax literature. Frequently, commentators define imputed income in such a way as to include in-kind income produced by one family member for another. ${ }^{243}$ For example, when one parent enables the other parent to enter or remain in the waged labor force by providing necessary child-care services in the home, this transaction usually is analyzed under the rubric of imputed income. ${ }^{244}$ Expansion of imputed income to mean more than the production of in-kind income for oneself so that it includes the production of in-kind income for other family members can be challenged within conventional tax analysis, as well as within a tax analysis that includes the antisubordination principle.

Treating intrafamily transfers of in-kind income as imputed income ignores a basic tenet of the income tax-that it is an individual income tax. Except for the provisions related to the joint income tax return for married couples, the Code is framed to determine the taxable income of each individual taxpayer, making no exception for intrafamily transactions. On the contrary, the Treasury and Congress have devoted considerable efforts through litigation and tax reform to prevent unwarranted assignments of income through intrafamily transfers. ${ }^{245}$ One significant reason why the exclusion of intrafamily transfers of in-kind income from imputed income has gone unchallenged is the policymakers' general reluctance to tax it. Taxation, however, is not the inevitable conclusion if the intrafamily transfers were not treated as imputed income. Taxation could be avoided by using conventional tax analysis regarding gifts ${ }^{246}$ or quid pro quo

243. See, e.g., ANDREWS, supra note 237, at 74; CHIRELSTEN, supra note 232, at 23-24

244. In this example, the parent who cares for the children should be understood as in part producing imputed income and in part income for the other parent and children. The care-giving parent is personally benefited by providing child care for her or his own children, while simultaneously producing a benefit for the other parent who also has an obligation to provide the childcare.

I am grateful to Gwen Thayer Handelman for her insights on the inadequacies of the definition of imputed income, which is generally found in the tax literature.

245. E.g., Commissioner v. Culbertson, 337 U.S. 733 (1949) (reversing the appellate court's decision holding a family partnership between a father and his four sons to be legitimate and remanding to the tax court for determination of which, if any, of the sons were legitimate partners, and thus who would be liable for taxes on the income generated by the business); Lusthouse v. Commissioner, 327 U.S. 293 (1946) (finding that a partnership between a husband and a wife, which allowed the husband's eamings to be reported as the wife's income, was not genuine); Commissioner v. Tower, 327 U.S. 280 (1946) (finding that a relationship similar to Lusthouse was not genuine); Harrison v. Schaffner, 312 U.S. 579 (1941) (finding the trust beneficiary responsible for taxes on the entire amount of income from the trust, regardless of her assignment to her children of specific amounts of the income); Lucas v. Earl, 281 U.S. 111 (1930) (finding a husband's entire income taxable to him regardless of his assignment by contract of half of his income to his wife); I.R.C. $\S 7872$ (treating forgone interest on below-market gift loans as having been transferred to the borrower and retransferred to the lender as interest).

246. As a gift, the in-kind income would be excluded from taxation in the recipient's tax base under I.R.C. $\S 102$. The in-kind income would be excluded from the donor's tax base by looking to general tax principles of administrability. There are many instances in the tax law, for reasons of administrability, that exclude income. The administrability reasons include issues of privacy, as well as a determination that the high number of transactions of relative minimal value warrants exclusion. The I.R.S. already takes this position regarding transfers of in-kind income of services to friends and acquaintances. See I.R.C. $\$ 6045$ (requiring information reporting by any "barter exchange"); Treas. Reg. § 1.6045-1(a)(4) (as amended in 1996) (excluding from the term barter exchange "arrangements that provide solely for the informal exchange of similar services on a non-commercial basis"); see also Rev. R. 80-52, 1980-1 C.B. 100 (holding credits earned by the performance of services in a barter club taxable). It takes a similar position regarding transfers of in-kind 
exchanges along with the principle of administrability ${ }^{247}$ or by relying on precedent regarding payments to satisfy support obligations. ${ }^{248}$

Making the antisubordination principle a part of tax analysis leads to the question of why policymakers have relied on imputed income, rather than other tax concepts, to conclude that intrafamily transfers of in-kind income should not be taxed. The effect of treating an intrafamily transfer of in-kind income from services, mostly reproductive labor, as imputed is to make the person who produces the work and the productive value of the work itself invisible under the tax law. The central purpose of the concept of imputed income is to acknowledge economic benefit produced outside of the marketplace. Within this family context, submerging the identity of the worker into the identity of the beneficiary of the work means that the tax law is indifferent as to who is actually doing the work. Through that indifference, the tax law devalues the reproductive labor even as it acknowledges the economic value produced by it. The historical role that class, gender, and racial hierarchies have played within reproductive labor makes the tax law's submergence of reproductive labor and the reproductive laborer under the rubric of imputed income particularly pernicious. ${ }^{249}$

income of property among family members, with the exception of below-market loans. See I.R.C. § 7872. The gift analysis might apply even if family members exchange in-kind income with each other. Although mutual gifts might seem like a contradiction in terms, within a family setting that conclusion may accurately reflect the nature of the economic transactions

247. Even if we were to conclude that an intrafamily transfer of in-kind income of services is in exchange for other in-kind income of services or of property or for cash or other property, that does not mean that taxation is inevitable. For one thing, it is possible that the cost of one family member acquiring in-kind income of services may be deductible as an expense, such as for employment-related child care. For another, the exclusion of this income from tax could be based on principles of administrability as was indicated above regarding the gift approach. See supra note 246.

248. The U.S. Supreme Court held, in Gould v. Gould, 245 U.S. 151 (1917), that payments made to satisfy a support obligation are not income to the recipient for tax purposes. Although the reasoning in this early case is troubling because it narrowly defined income as including only income arising from a business transaction or contract contrary to a broader definition of income later adopted by the Supreme Court in Commissioner v. Glenshaw Glass Co., 348 U.S. 426 (1955), it nevertheless supports the proposition that intrafamily transfers in satisfaction of support obligations are not taxable. Tax provisions subsequently enacted regarding the treatment of payments made pursuant to separation and divorce agreements can be reconciled with this view. See I.R.C. \$ 71 .

249. Evaluating the categorization of in-kind services using the antisubordination principle reveals that even if the in-kind services are conceptualized as a gift, a quid pro quo for other services, property, cash, or satisfaction of a support obligation, they remain grounded in the public/private distinction and, therefore, risk perpetuating class, gender, and racial hierarchies. A closer examination of the different tax approaches, however, shows that they do not all create the same level of risk. Recognizing in-kind services as a gift or as a satisfaction of a support obligation keeps the intrafamily transfer of in-kind services a private transaction. By remaining within the private realm, both conceptualizations of the transfer of in-kind services reinforce treating reproductive labor as not productive. Nevertheless, from an antisubordination perspective, the gift and support approaches are preferable to one based on imputed income. To analyze the transfer as a gift or as support acknowledges the worker, the worker's ownership in the economic value produced, and the worker in the subject position of having transferred economic value. Although no market price is placed on the economic value of the in-kind income from services, the gift approach has the further advantage of challenging the recipient of the services to be grateful for them and encouraging the recipient not to assume that, by virtue of the family relationship, they were rightfully due. The gift and support approaches with their emphasis on the private side of the public/private distinction, of course, reflect the historical and contemporary views of reproductive labor. In that regard, the gift and support approaches make little difference in disrupting the class, gender, and race subordination associated with reproductive labor. The gift and support approaches, however, hold the potential of not treating the reproductive labor or the laborer as invisible and, under the 


\section{The Interrelationship Between the Business/Personal Distinction and Imputed Income}

Even if we ignore the ideological consequences of treating one family member's work as the imputed income of another and adopt the broad definition of imputed income conventionally employed in tax law, traditional analysis, relying on the business/personal distinction and the concept of imputed income, remains inadequate to determine the appropriate tax treatment of child-care expenditures. A typical rationalization of the business/personal distinction is to link an expenditure to the production of imputed income. ${ }^{250}$ So long as imputed income is excluded from taxation, the tax logic under the Haig-Simons ideal tax base requires that any expenditures incurred in the marketplace to produce that untaxed income must also be excluded from the tax computation. ${ }^{251}$

For example, if a taxpayer bought a tomato plant for $\$ 3$, planted and weeded it through the early summer, and then ate the tomatoes produced at the end of the summer, the taxpayer cannot deduct the $\$ 3$ paid for the plant. The taxpayer is denied a deduction for the cost of the plant because she used the plant to produce imputed income in the form of tomatoes that were consumed outside of the marketplace. If the same taxpayer had taken the harvested tomatoes to a local farmers' market and sold them, however, she could deduct the $\$ 3$ paid for the plant because the tomatoes were sold in the marketplace for others to consume.

The argument that the cost of food that a taxpayer consumed makes it possible for that taxpayer to be productive in the marketplace has never been accepted. On the contrary, determining deductibility of the cost of the tomato plant, depending on what the taxpayer did with the tomato, generally has been treated as an easy question based on the obvious distinction between business and personal purposes. Determining whether child-care costs, however, produced taxed income (business) or untaxed imputed income (personal) has been recognized as not so easy even under traditional tax analysis. Nothing in the conventional analysis of imputed income or the business/personal distinction tells us whether it is more appropriate in an accretion tax system to look solely to

antisubordination principle, that potential justifies preferring either of these approaches to the imputed income one.

The quid pro quo approach carries all the advantages of the gift and support approaches. It goes further, however, in contesting the public/private distinction. It acknowledges that productivity occurs in households and that the economic value produced can be transferred in a manner that mirrors transactions typically associated with the marketplace. By using the language of exchange, the approach explicitly recognizes that the recipient of the in-kind income needed and valued those services. So long as the in-kind income is excluded from the tax base of the reproductive laborer for administrative reasons having to do with privacy and the difficulty of valuation and record-keeping, the quid pro quo approach has only limited benefit. Compared to the imputed income approach, however, it establishes a tax approach that would support and reinforce social and economic changes under which reproductive labor would no longer be degraded.

250. See, e.g., CHIRELSTEN, supra note 232, at 165-68.

251. See SIMONS, supra note 13, at 118-19, in which Simons suggests this result when discussing the practical insignificance of income from a non-durable good because "the difference between the value of its use and its original cost is obviously small." 
the fact that the costs of the child-care services benefited the children and their parents (imputed income) ${ }^{252}$ or to look solely to the fact that the costs of the child-care services permitted the parents to enter the waged labor market.

The inadequacy of the tax concepts of business/personal and imputed income is demonstrated further when the deduction of child-care expenditures is analyzed by comparing families with children and families without children. If a two-waged-worker family with young children is compared to a one-wagedworker family with young children, then a deduction for child-care expenditures seems appropriate under traditional tax analysis. ${ }^{253}$ The imputed income produced by the non-waged worker in providing child-care services is not subject to tax. The same tax result can be achieved for the two-waged worker family only by allowing a deduction for child-care expenditures. Both families have young children in need of childcare and both families have two workers. The only difference is that one family has a worker who remains out of the marketplace and personally provides child-care services, permitting the other parent to earn market wages, while the other family has two workers in the marketplace and pays someone else to perform those services. The comparison of these two families leads to a tentative conclusion that child-care expenditures are a cost incurred to allow workers in both families to earn waged income. A deduction for child-care expenditures acquired in the marketplace by the twowaged worker family can be understood as achieving tax equity and economic rationality. ${ }^{254}$ By allowing a deduction for child-care expenditures, the law ensures similar tax liabilities between those families that enjoy imputed income from child-care services and those who do not. ${ }^{255}$

252. The dichotomy in the text adopts conventional tax analysis. It fails to acknowledge the possibility that the costs of producing human capital, through child-care expenditures, is at least partially an investment that would produce income in the future. See supra note 236 and accompanying text

253. For ease of exposition I will use the term deduction to refer to the tax treatment of child-care expenditures because, for purposes of this discussion, the distinction between a deduction and an exclusion from income, such as the one provided in I.R.C. $\$ 129$, and the distinction between a deduction and a credit, such as the one provided in I.R.C. $\S 21$, are not relevant.

254. See CHIRELSTEIN, supra note 232, at 24; David S. Davenport, Education and Human Capital Pursuing an Ideal Income Tax and a Sensible Tax Policy, 42 CASE W. RES. L. REV. 793, $841-46$ (1992); Lawrence Zelenak, Marriage and the Income Tax, 67 S. CAL. L. REV. 339, 372-73 (1994).

255. Although the tax literature frequently pronounces that imputed income from services is not subject to the income tax, see CHIRELSTEN, supra note 232, at 22-25, that statement is misleading. The tax law may not tax imputed income from services directly, but it can tax it indirectly. If the tax law allows a deduction for an amount paid for the same services in the marketplace, then the imputed income is taken into account in the tax base indirectly. The effect of allowing a deduction for the expense of acquiring child-care services in the marketplace is to tax the imputed income produced from child-rearing services performed by a parent.

For example, if a taxpayer, $T$, prepares her own tax return, she has earned imputed income by performing those services. The tax law does not tax $T$ 's imputed income directly. The tax law does tax her imputed income indirectly, however, because, by performing those services for herself, $T$ is denied the right to deduct their value. $T$ can only enjoy that deduction by hiring someone to prepare the tax return. See I.R.C. $\$ 212(3)$. Thus, whether $T$ forgoes earning taxable income by spending time preparing the tax return or earns money for the purposes of paying to have the tax return prepared by someone else, the tax law treats $T$ the same. In both instances, the effect on $T$ 's taxable income is zero. In the first instance, the tax law excludes the imputed income from $T$ 's gross income and denies any deduction for the value of services she provided for herself. In the second instance, the tax law includes the marketplace earnings in $T$ s gross income, but allows a deduction for the amount $T$ paid to have the tax return prepared. 
If a similar analysis is applied to a two-waged worker family with young children and a two-waged worker family without young children, however, a deduction for child-care expenditures is arguably inappropriate. The comparison of these two families reveals an alternative to the view that child-care expenditures enable a taxpayer to enter the waged work force. The comparison of families with and without young children is the basis for an argument that having children is a consumption choice and that the cost of caring for those children should not be deductible. The fact that not every worker/taxpayer has child-care needs allows for an argument to be made that child-care expenditures are an item of consumption unrelated to income-producing activity for which a deduction should be available. To make that argument, however, ignores the economic productivity involved in the rearing of children. That is to say, the argument itself is based on the business/personal distinction, with child rearing being treated as personal.

The family situations just described, of course, do not exhaust the kinds of family situations where child-care needs arise. If a single-parent family with young children is compared with a single person without young children and if the view that having children is a consumption choice prevails, it would seem to have equal force here as in the previous comparison. ${ }^{256}$ By relying exclusively on

An altemative description of the tax consequences of the tax-return preparation example is to say that the income earned in the marketplace that was then used by $T$ to pay someone else to prepare her tax retum is excluded from gross income. If $T$ prepares the return, the value of the services (imputed income) is excluded from gross income; if $T$ earns the money for the purpose of buying those tax preparation services, that income is excluded from gross income. Yet another alternative description of the tax consequences of the tax-return preparation example is to say that the value of $T$ s tax-preparation services (imputed income) is included in her gross income and then deducted as an expenditure necessary to determine taxable income. If $T$ prepares the return, the value of the services (imputed income) is included in gross income and then deducted; if $T$ earns the money for the purpose of buying those tax preparation services, that income is included in her gross income and the cost of the services are deducted.

The treatment of taxpayers as the same regardless of whether they prepare their own tax returns or have them prepared by someone else achieves the tax goals of equity and economic rationality. The deduction for the cost of tax preparation services assures equity by treating taxpayers who buy tax preparation services the same as taxpayers who prepare their own returns. The deduction also assures economic rationality by eliminating any tax benefit to those who prepare their own returns, because whether taxpayers prepare their own returns or pay someone else to do it, the tax consequences are the same.

Although the foregoing discussion is theoretically accurate, it is in practice misleading. A deduction for tax preparation is a miscellaneous itemized deduction, which means that it is not deductible to the extent that the taxpayer's other miscellaneous itemized deductions do not exceed two percent of adjusted gross income. See I.R.C. $\$ 67(\mathrm{~b})$. This categorization is further limited to the extent the taxpayer elects to take the standard deduction. See I.R.C. $\S 63(\mathrm{~b})$. These limitations on the deductibility of the cost of tax retum preparation means that imputed income from preparing one's own tax return enjoys preferential treatment notwithstanding the deduction provided under I.R.C. $\$ 212(3)$

The imputed income/deduction relationship becomes more complicated and more politically charged when the tax analysis concerns childcare, as opposed to tax preparation, costs. One reason the analysis becomes more complicated is that, unlike tax preparation services in which all taxpayers have the obligation to file tax retums, not all taxpayers have children who are young enough to need child-care services. Therefore, the goal of designing a tax that treats similarly situated persons similarly is not so obviously achievable because, as the text suggests, it is less clear with whom a taxpayer should be compared

256. If a single-parent family with young children is compared to a two-parent family with young children, the argument for a deduction for child-care expenditures might initially seem stronger for the singleparent family and less strong for the two-parent family. Incurring child-care expenditures might seem to be less of a necessity of wage earning when it is possible that one parent could stay home to care for the child while 
traditional tax principles and analysis, we see that the various comparisons of family situations provide some insight as to what is at stake when deciding the proper tax treatment of employment-related child-care expenditures. Traditional tax principles, however, provide no clear answer to the question of whether child-care expenditures should be deductible. They provide no clear answer because the principles provide no framework for deciding whether child rearing is personal or predominantly personal and because, even if child rearing is considered personal, the principles provide no framework for evaluating the deductibility question, in terms of either tax equity or economic rationality. The inadequacy of the tax principles becomes even more obvious once we recognize that the business/personal distinction and the imputed income concept serve to obscure the role of child-care workers and the impact on them of tax rules that determine whether their compensation is deductible to their employers (childcare consumers).

\section{The Politics of the Invisibility of the Child-Care Worker in Traditional Tax Analysis}

Within the historical context of waged domestic work and the relation of its invisibility to the nineteenth-century middle-class homes in which that work was done, the invisibility of the domestic worker found within twentieth-century tax analysis should be unsettling. It should be made even more unsettling when, in the development of specific tax proposals, we find political foes defending their respective positions by appealing to the middle class with arguments that depend on the invisibility of the child-care worker. The hearings held by the Senate's Committee on Finance on H.R. 8300, which was the bill that ultimately became the Tax Code of 1954, starkly show, through a comparison of discussions having to do with the tax deduction for depreciation of machinery used in business and with employment-related child-care expenditures, how the invisibility of childcare workers served the interests of the middle class.

In 1954, the Secretary of the Treasury, George M. Humphrey, testified before the Committee on Finance. His testimony covered a wide range of tax reforms, including accelerated depreciation rules for equipment used in business and the deduction for employment-related child-care expenditures. In support of the Eisenhower Administration's proposed accelerated depreciation rules, Secretary Humphrey argued:

To have real prosperity in America, we cannot stimulate consumer buying alone. Large tax cuts to millions of individuals just to buy

\footnotetext{
the other parent provides waged earnings. That analysis is flawed, however, because it assumes that a wageearning parent has no child-care responsibilities that need to be met if the other parent remains in the home to perform those duties. All wage-eaming parents have child-care needs; the difference is that some meet these needs by acquiring child care in the marketplace and others by having those services provided to them within the household.
} 
consumer goods is not enough. Millions of people in this country earn their living making heavy things - big lathes, generators, heavy steel, and machinery that consumers do not buy. Such things are purchased by investors. Our tax program not only returns billions of dollars to consumers but also seeks to stimulate the investment of savings to buy the products of heavy industry-in the production of which so many millions of Americans get their livelihood. ... 257

During an exchange with Senator Russell B. Long from Louisiana, the Secretary remained focused on the workers making the machines and those employed by the businesses buying the machines.

Senator Long. If he [the businessman] makes more profits and continues to expand his business, where are you going to collect the tax? Secretary Humphrey. You get it out of the profits and out of the earnings of all the people working. Every time a man goes to work it helps the income tax....

Senator Long. You say you are getting it directly from the salaries of the laboring men?

Secretary Humphrey. Out of the wages and out of the profits of the business and out of the people who make these new machines. There are going to be a lot of people making them and there will be some profits there. If we can just stimulate the buying of machines and putting in the machines, our income taxes will go up. ${ }^{258}$

Secretary Humphrey's argument in favor of allowing businesses to deduct the cost of machinery in earlier tax years rather than later tax years was that this tax rule would increase employment. He de-emphasized the effect of accelerated depreciation deductions on the profits of both the seller and the buyer of the machinery; instead, he stressed the effect the tax reform would have on the workers producing the machinery and those using the machinery in their jobs.

The argument was made in the political environment of a congressional hearing and was presumably designed to garner public support. The fact that the argument was political underscores the importance of the form it took. Secretary Humphrey apparently believed that the senators and the American public would be more receptive to accelerated depreciation deductions if they understood how they served the interests of U.S. labor.

For comparison purposes, consider the responses of Secretary Humphrey and the Under Secretary of the Treasury, Marion B. Folsom, to Senator Long's questions concerning the proposed deduction for employment-related child-care

257. Act to Revise the Intemal Revenue Laws of the United States: Hearing on H.R. 8300 Before the Senate Comm. on Finance, 83d Cong. 96 (1954).

258. Id. at 119 
expenditures.

Senator Long.

Is there any reason why [the deduction for expenses] should not be more than $\$ 600$ ? Is it that this proposal to recognize the expense of a working mother employing a baby sitter just the same as a businessman who has to employ a night watchman while he is away from his business?... You completely exempt the businessman for the expense of hiring a night watchman, don't you? Is there any reason why you shouldn't completely exempt a widow who has no husband and no one in the family to look after the children while she is gone for the expense of hiring a baby sitter?

Mr. Folsom. There is no exemption now and we think $\$ 500$ or $\$ 600$ would be all right. This will cost us $\$ 40$ million.

Senator Long. As between individuals, wouldn't it seem that she is perhaps even more entitled to that deduction than some of those people who draw corporation dividends?

Mr. Folsom. It is very difficult to administer this, anyhow ... Senator Long. What would the reaction be of the Treasury Department to a proposal to permit working mothers to deduct that same expense of hiring a baby sitter, even though their husbands are able to work, even though they are married and their husbands are able to work? ... [Is the only objection] that it would add to the cost?

Secretary Humphrey. No, Senator, we are definitely opposed to that.

The Ways and Means Committee held long hearing on that and many of the child-care organizations and many of the churches and a great many people came in and objected to it. The Ways and Means Committee selected this as the proper way to do it.

Senator Long. What is the argument against it? It is not a question of who objects, but what is the argument against it?

Secretary Humphrey. The child-delinquency cases.

There are great arguments that the mother ought to be at home looking after children where there is a wage earner in the family. ... We are in favor of doing it this way and limiting it in this manner.

Senator Long. Actually, though, isn't that every bit as much of a legitimate expense on the part of a mother who feels that she must work, even though she is married, as it is on behalf of a businessman who has to hire that night watchman I was speaking of.

Secretary Humphrey. That is right. [The hearing then moved on to another provision. $]^{259}$

Asked to defend the limitations on the deductibility of child-care expenditures, Secretary Humphrey and Mr. Folsom spoke about administrability problems, 
loss of tax revenue, and child delinquency. Although they conceded the incomeproducing aspect of child-care expenditures, they did not adopt business or economic arguments to support the limitations in any of the ways they used business and economic arguments to support accelerated depreciation deductions.

Further comparison of the two interchanges reveals the inadequacy of the tax policy arguments made. The taxable transaction that leads to accelerated depreciation deductions is the purchase of machinery. Secretary Humphrey preferred, however, to emphasize the related transactions of hiring workers to make and use the machinery. In contrast, the taxable transaction that leads to the deduction of employment-related child-care expenditures is, in fact, the hiring of a worker-a waged worker hired to perform child-care services. Secretary Humphrey, Mr. Folsom, and Senator Long all preferred, however, to emphasize the related transaction of the child-care consumer (the mother of the child) leaving the home and entering the waged workforce. The explanation for the different emphasis placed on the hiring of a worker who makes or operates a machine and one who cares for children can be found by looking to the underlying similarities between the two interchanges.

In both cases, the Eisenhower Administration's position is being constructed to obtain the support of the middle class. For accelerated depreciation deductions, the Secretary appealed to the middle class by showing them how their "livelihood" depended on an expanding economy. For child-care expenditures, the Secretary and the Under Secretary appealed to the middle class by emphasizing fiscal responsibility and child welfare. Senator Long's questions were also constructed to appeal to the middle class. His attack on the accelerated depreciation deduction was on behalf of middle-class workers/taxpayers, whom he saw as having conflicting interests with their employers and other investors. He saw middle-class workers paying higher taxes while the propertied class of entrepreneurs and investors reaped higher after-tax profits. His attack on the limitations to the child-care deduction were also on behalf of the middle class. He was stating the case on behalf of the lady-like worker and her family. Neither Senator Long, nor Secretary Humphrey, nor Mr. Folsom had any political interest in making the case for and on behalf of the child-care worker. On the contrary, her invisibility was required for the interests of the middle class to be served. That was true in the nineteenth-century home; it remains true in twentiethcentury debates about tax reform. ${ }^{260}$

260. But see id. at 1061 (Statement of Mrs. Ranice W. Davis from John Hopkins School of Medicine on behalf of a number of women interested in the child-care deduction) ("I might add, of course, we feel that every child-care attendant employed is increasing the employment in the country."). 
IV. EMPLOYMENT-RELATED CHILD-CARE EXPENDITURES AND TRADITIONAL TAX LITERATURE: THE MYTH OF OBJECTIVITY

Part III showed how the traditional tax concepts of the business/personal distinction and imputed income failed to produce either certainty of tax treatment or objectivity. It showed instead that the concepts, as developed and applied, are a reflection of social and economic hierarchies traceable to the nineteenth century that contribute to the invisibility of reproductive labor and the women who perform it. Part IV continues this discussion by showing how some of the most influential and respected tax writings of the twentieth century relied upon social stratification to reach so-called objective conclusions about the proper tax treatment of employment-related child-care expenditures.

I would identify the writings of three men as having a major influence on the approaches typically found in the tax literature on employment-related child-care expenditures. The first is Henry Simons's Personal Income Taxation, published in $1938 .{ }^{261}$ The importance of this book in modern tax analysis cannot be overstated. As indicated earlier, Simons's work became the basis for developing the concept of the ideal accretion $\operatorname{tax}^{262}$ and tax scholars frequently use his writings as the starting point for considering a wide range of tax issues. ${ }^{263}$

The second is the 1939 opinion of Judge Opper in the case of Smith $v$. Commissioner. ${ }^{264}$ This opinion is important because it was the first of a relatively small number of cases concerning the issue of employment-related child-care expenditures that were decided before Congress addressed the issue by statute. ${ }^{265}$ It also has been made important because it is frequently used in basic individual income tax courses to teach students the business/personal

261. See SimONS, supra note 13, at 110-11.

262. See supra note 228 and accompanying text.

263. See, e.g., William D. Andrews, A Consumption-Type or Cash Flow Personal Income Tax, 87 HARV. L. REV. 1113, 1113-14 nn. 1 \& 4 (1974); Joseph Bankman \& Thomas Griffith, Is the Debate Between Income Tax and a Consumption Tax a Debate About Risk? Does it Matter?, 47 TAX L. REV. 377, 378 (1992); Noel B. Cunningham \& Deborah Schenk, Taxation Without Realization: A "Revolutionary" Approach to Ownership, 47 TAX L. REV. 725, 728 (1992); Richard A. Epstein, The Consumption and Loss of Personal Property Under the Internal Revenue Code, 23 STAN. L. REV. 454, 455 (1971); Daniel I. Halperin, Interest in Disguise: Taxing the "Time Value of Money", 95 YALE L.J. 506, 508-09 (1986); Paul B. Stephan III, Federal Income Taxation and Human Capital, 70 VA. L. REV. 1357, 1359 n.2 (1984); Jeff Strnad, Taxation of Income from Capital: A Theoretical Reappraisal, 37 STAN. L. REV. 1023, 1024-34 (1985); Deborah M. Weiss, Can Capital Tax Policy Be Fair? Stimulating Savings Through Differentiated Tax Rates, 78 CORNELL L. REV. 206, 211-13 (1993).

264. See 40 B.T.A. 1038, aff'd per curiam, 113 F.2d 114 (2d Cir. 1939).

265. See supra notes $158-60$ and accompanying text (describing Congress's enactment of a tax deduction for employment-related child-care expenditures). For another case denying employment-related child-care expenditures, see O'Connor v. Comm'r, 6 T.C. 323 (1946). See also Nammack v. Comm'r, 56 T.C. 1379 (1971), aff'd mem., 459 F.2d 1045 (2d Cir.), cert. denied, 409 U.S. 991 (1972) (unsuccessfully challenging the constitutionality of the limitations on employment-related child-care expenditures provided under the now repealed I.R.C. $\S 214$ based on evidence that they imposed a particular burden on working women); accord Black v. Comm'r, 69 T.C. 505 (1977). For other cases involving the deductibility of child-care expenditures under the provision permitting medical expenses to be deducted, see Ochs v. Comm'r, 195 F.2d 692, cert. denied, 344 U.S. 827 (1952); Wendell v. Comm'r, 12 T.C. 161 (1949). 
distinction. ${ }^{266}$ By its inclusion in standard tax teaching materials, its reasoning has had a far greater impact on tax discourse than it might otherwise have had.

The third is the 1973 publication of Pathways to Tax Reform: The Concept of Tax Expenditures written by Stanley Surrey. ${ }^{267}$ This book represents the culmination of Surrey's work developing the concept of tax expenditures that he first began to consider while Assistant Secretary for Tax Policy in the Treasury Department in the late $1960 \mathrm{~s}^{268}$ His influential position in government combined with his prominence as a teacher and scholar at Harvard Law School allowed Surrey to showcase the concept of tax expenditures and his agenda for tax reform. Although academics have debated the usefulness of the tax expenditure concept, it is widely recognized as having had a substantial influence on the making of federal tax laws. ${ }^{269}$ In many respects, the concept of tax expenditures is derived from the ideal income tax base developed by Simons. Surrey's contribution was to show how, through identifying tax expenditures, political pressure could be created for adoption of tax reforms that would make the Code more nearly reflect the ideal income tax base. Whether policymakers and scholars agree or disagree with the concept, none of them deny that it changed the nature of tax discourse. Since the late sixties, conventional analysis typically includes consideration of the question of whether the tax item (credit, deduction, or exclusion) is a tax expenditure or an item necessary to a determination of the ideal income base. ${ }^{270}$

\section{A. Henry Simons: The Definition of Income}

Henry Simons's comments about child-care expenditures are quite minimal, but the context in which those comments arise is significant. According to Simons,

Measurement of consumption presents insuperable difficulties to achievement of a rigorous conception of personal income. ... [F]rom the point of view of equity in taxation, the consumption of goods and services produced within the household or individual economy presents

266. See, e.g., ANDREWS, supra note 237, at 541-42; STEPHEN B. COHEN, FEDERAL INCOME TAXATION 128-29 (1989); MichaEl J. GraETZ \& DEBORAH H. SCHENK, FEDERAL INCOME TAXATION: PRINCIPLES AND POLICIES 270-71 (3d ed. 1995); KLEIN \& BANKMAN, supra note 237, at 568-72.

267. See SURREY, supra note 15.

268. See id. at vii-viii.

269. See Thomas D. Griffith, Theories of Personal Deductions in the Income Tax, 40 HASTINGS L.J 313, 349-52 (1989); Daniel Shaviro, Beyond Public Choice and Public Interest: A Study of the Legislative Process in the 1980s, 139 U. PA. L. REV. 1, 62 (1990); Victor Thuronyi, Tax Expenditures: A Reassessment, 1988 DUke L.J. 1155, 1163-81; Edward A. Zelinsky, James Madison and Public Choice at Gucci Gulch: $A$ Procedural Defense of Tax Expenditures and Tax Insititutions, 102 YALE L.J. 1165, 1165-71 (1993).

270. See, e.g., Joseph M. Dodge, Taxing Human Capital Acquisition Costs-Or Why Costs of Higher Education Should Not Be Deducted or Amortized, 54 OHIO ST. L.J. 927, 968, 970-81 (1993); Jonathan B. Forman, Reconsidering the Income Tax Treatment of the Elderly: It's Time for the Elderly to Pay Their Fair Share, 56 U. PITT. L. REV. 589, 604-12 (1995); Weiss, supra note 263, at 215-17. 
real imponderables. Clearly inequitable results arise whether such items are consistently included or ignored.

To exclude them is obviously to penalize specialization. If A works nine hours a day and pays for care of his garden with the proceeds of one hour's work, he would be overtaxed relative to B, who works eight hours at the same hourly rate and maintains a similar garden by giving daily one hour of his own time. Families where wives pay for their housework from their own earnings outside the home would also be relatively overtaxed. Similar cases might be multiplied ad nauseam.

On the other hand, if the value of goods and services produced within the household are to be accounted for, one must face, first of all, the necessity of stopping somewhere; and no convenient stopping-place is discernible. Shall one include the value of shaves? of instruction to children? of a mother's services as a nurse? [emphasis added]

But further problems appear. Even if one be satisfied with the decision to include only the sort of goods and services commonly obtained by exchange (and such a rule is certainly not very helpful), the results will often seem unfair. Mrs. A does her own housework, while Mrs. B prefers to economize on other things and hires a maid. To impose additional taxes upon the A family is, so to speak, to penalize industry and subsidize leisure-and in a not readily defensible manner. If Mrs. A prefers to do her own work and spend on good entertainment what would otherwise go as wages to a maid rather than have time for bridge and modern fiction, it is hard to see why more income tax should be imposed on that account. The enjoyment of leisure is merely a form of consumption; and the choice between leisure and goods is of the same order as that among economic goods generally. Surely there is a strong presumption against any differentiation, under income taxes, according to the form which one's consumption may take.

All this, however, may only suggest the impropriety of taxing as income what may be called "earned income in kind." If it is not equitable to exclude such items entirely, this may be recognized in the most flagrant cases by allowing small, additional exemption with respect to the "earned income" of a wife. . . In general, however, it would seem that considerations of justice, not to mention those of administration, argue here for [a] rather narrow definition of taxable income. ${ }^{271}$

Although Simons admitted at the outset that "inequitable results arise whether such items [of imputed income] are consistently included or ignored, ${ }^{, 272}$ he ultimately concluded that ignoring imputed income is the preferred solution and, if anything is done about the "'earned income' of a wife," it should be a "small,

271. SIMONS, supra note 13 , at 110-12 (footnotes omitted).

272. Id. at 110 . 
additional exemption."273 How Simons could begin a discussion of imputed income apparently fully appreciating the imponderability of imputed income and end it with such clear conviction that imputed income should be ignored is worth investigating. It is especially worth investigating for our purposes because of the role childcare plays in the form of argument he adopts.

His discussion about the taxation of imputed income from services takes a number of turns. The first is when a comparison of a waged worker and a waged worker/gardener is abandoned for a consideration of families where the wife is a waged worker purchasing housecleaning services. ${ }^{274}$ Although not mentioned, the assumption seems to be that the husband is also a waged worker. Why was it important to Simons to shift from the single-waged worker to the two-wagedworker family? In the last line of the paragraph, Simons indicated that he saw them as raising the same type of issues when he said "[s]imilar cases might be multiplied ad nauseam." 275 That would suggest, at least at the outset, that the tax law leads frequently to inequitable results if imputed income is ignored.

The reference to family and wives seems to signal the next turn in his analysis that takes the form of a set of examples. But for the reference to shaving, the other reproductive labor examples involve the work historically associated with mothers and wives providing services to other family members, including the instruction to children and nursing of children. ${ }^{276}$ Although there is some ambiguity in this part of his reasoning, one reading is that this list represents items of imputed income for which the law would encounter significant difficulties if it tried to tax their value. In the paragraph that immediately follows, Simons suggested taxing only those items that could be acquired in the marketplace ${ }^{277} \mathrm{He}$ never told us whether he believed that shaving, instruction to children, and the nursing of children should be excluded from taxation on that basis. ${ }^{278}$ The fact is, however, that all these services (including shaving) could be "obtained by exchange."279 Throughout the early part of the twentieth century, which is the time period of primary concern for him, household workers assisted with child-care duties as well as housecleaning in middle-class households. ${ }^{280}$ On the other hand, an argument in favor of a reading that he believed these services are not readily available in the marketplace can be made if we focus on his examples of childcare: "instruction of children" and "a mother's services as a

273. Id. at 111

274. See id. at 110. See supra notes $243-49$ and accompanying text (noting that imputed income is defined to include services provided by one family member for another without any inquiry as to why that is the appropriate result).

275. SIMONS, supra note 13 , at 110.

276. See id. at 110. See supra notes 45-67 and accompanying text (describing the role reproductive labor played in establishing the boundaries between the public marketplace and the private home).

277. See SIMONS, supra note 13 , at 111 .

278. See id. at 110-11.

279. Id. at 111 .

280. See supra notes 87-92, 101, 103-04, 107-08, 118-28 and accompanying text (describing the labor history of waged domestic workers in the early part of the twentieth century). 
nurse." 281 The grammar of respectability, degeneracy, and stratified reproduction provides us with the insight that the types of child-care tasks Simons referred to are most closely associated with middle-class identity and the perpetuation of that identity. ${ }^{282}$ Acknowledging that certain child-care duties could not be delegated to waged household workers avoided a wide range of contradictions and anxieties within middle-class life. Simons successfully avoided those troubling identity issues through ambiguity. By so doing, he left his work susceptible to an interpretation that could be used to strengthen the public/private distinction along with the hierarchical relationships embedded within it.

His argument took a more disturbing turn. No longer was he making the comparison between a taxpayer who produced taxable income in the waged labor market and one who produced imputed income through unwaged labor. Instead, he was comparing the choices made by two women, both of whom apparently were not in the waged labor market. ${ }^{283}$ One chose to do housecleaning and spend her money on "good entertainment."284 The other chose to pay someone else for housecleaning so that she might entertain herself by playing "bridge" and reading "modern fiction." 285 With this comparison of potential taxpayers, who could disagree with Simons's conclusion that "[s]urely there is a strong presumption against any differentiation, under income taxes, according to the form which one's consumption may take" $?^{286}$ What happened to the waged worker who worked fewer hours at his job to do some gardening or the wagedworking wife who paid for housecleaning services? ? $^{28}$ Once Simons started comparing different forms of imputed income, his analysis of the issue of imputed income no longer included waged workers. ${ }^{288}$ From the immediately preceding comparison of bridge playing and housecleaning, Simons concluded that "[a]ll this ... suggest[s] the impropriety of taxing as income what may be called earned income in kind.",289

What started out as a consideration of difficult questions ${ }^{290}$ ended with a consideration of a quite easy one. ${ }^{291}$ Simons explicitly used a model of the gender roles associated with white, middle- or upper-class families to reach that

281. SIMONS, supra note 13 , at 110.

282. See supra notes 64-66 and accompanying text (describing the tensions within the middle-class home that led to the denigration of waged child-care work and the women who performed it).

283. See SMMONS, supra note 13, at 111

284. Id.

285. Id.

286. Id.

287. See id. at 110.

288. See id. at 111 .

289. Id.

290. See $i d$. at 110 (stating that "[m]easurement of consumption presents insuperable difficulties to achievement of a rigorous conception of personal income").

291. See id. at 111 (stating in reference to Mrs. A, who cleans her own home, and Mrs. B, who hires a housecleaner so that she may have more time for bridge and modem fiction that "[s]urely there is a strong presumption against any differentiation, under income taxes, according to the form which one's consumption may take'). 
easy question and obscure the more difficult ones in his analysis. His shift from the waged worker/unwaged gardener to the unwaged housecleaner/unwaged bridge player was only possible because women are associated with the responsibility of maintaining a clean house, either because they do it themselves or because they are in charge of hiring someone else to do it. ${ }^{292}$ His references to child rearing and mothering without an accompanying comparison to waged work were also convincing because motherhood is so tightly linked to who women are. ${ }^{293}$ The tax law and society remained in equilibrium as Simons's analysis proceeded.

The final step in his argument had to do with wives (referred to as Mrs. A and Mrs. B) and the choices they have in running a comfortable household. ${ }^{294}$ Running the household entails making choices among cleaning, playing bridge, reading fiction, or finding some other good entertainment. ${ }^{295}$ The nature of the choices are crucial to Simons's argument because, without saying so directly, he made "the wife" an unsympathetic family member, given the good life she leads. ${ }^{296}$ The fact that he was only describing those wives who have sufficient financial resources to stay at home and hire "a maid" was never defended because it did not have to be. ${ }^{297}$ The stereotype of the non-working wife was powerful enough to let his argument pass as the equivalent of sound analytical tax policy.

There is obviously a double edge to Simons's analysis and conclusion. One edge created a tax inequity for women who are engaged in waged work. By having Mrs. A and Mrs. B stand in for most women, Simons avoided dealing with women in the waged work force other than as exceptions to the general rule. ${ }^{298}$ Within this context, it became reasonable to propose only a "small" exemption for working wives to be available for only the "most flagrant cases. ${ }^{.299}$ In other words, he presented an ideal income tax base that depended on most women remaining in the category of lady.

The other edge is that, by having Mrs. A and Mrs. B stand in for most women, Simons undermined the nature of women's unwaged labor. ${ }^{300}$ The choices for most women are not between housecleaning and bridge. The choices are among housecleaning, washing clothes, paying bills, mending, child rearing, etc. To treat maintaining a household and leisure as comparable choices in the manner that Simons did was to reinforce the notion that unwaged labor is not productive, but self-indulgent and not economically valuable. ${ }^{301}$ Treating

292. See id. at $110-11$.
293. See id. at 110.
294. See id. at 111.
295. See id.
296. See id.
297. See id.
298. See id.
299. See id.
300. See id.
301. See id.


unwaged reproductive labor as having no value means that Simons's analysis and the tax system he was prescribing had the effect of undermining the concerns of women, whether or not they are in the waged labor market, by undermining the unwaged work they do at home. Further, by reinforcing the view that reproductive labor is not valuable, the tax analysis and the prescribed system bolstered the view that waged reproductive labor is inferior labor with the effect of justifying low wages and poor working conditions. Thus, through the unreflective use of gender stereotypes, Simons simultaneously strengthened the inferior status of the lady, as well as the hierarchy between the lady and the waged household worker.

Simons's analysis was made possible by the tenacious remnants of the nineteenth-century class, gender, and race hierarchies represented in the "cult of respectability." ${ }^{302}$ With that historical framework, we can fully appreciate how and why Simons could have engaged in what is at best a fragmented and ambiguous analysis. Furthermore, only by reference to the construction of respectability can we fully appreciate the potential class and racial/ethnic dimensions of his analysis. As we have seen, the cult of respectability was made possible by white middle-class women hiring other women to do hard and distasteful work like floor scrubbing and laundry. ${ }^{303}$ In the last half of the nineteenth century, domestic work burgeoned as the middle and upper-classes grew. ${ }^{304}$ The majority of the domestic workers that white women hired were immigrants and women of color. ${ }^{305}$ The effect of Simons's analysis was to reinscribe the nineteenth-century cult of respectability onto the ideal income tax base and twentieth-century tax law; that reinscription strengthened the class, gender, and racial divisions that continue to be associated closely in the U.S. political economy with household work. ${ }^{306}$ In fairness, the problem with the current tax law's treatment of reproductive labor is not Simons's-the problem lies with those of us who have carried forward his work into the modern income tax without interrogating our own assumptions and biases. Those assumptions and biases make it easy for us to ignore those passages where he expressed concerns about the tax treatment of a waged-working wife and to emphasize those passages equating reproductive labor and leisure activities.

\section{B. Smith v. Commissioner: Applying "Accepted Principles"}

Simons's analysis of imputed income from services, particularly child-care services, was echoed in the opinion by Judge Opper in Smith v.

302. See supra notes 45-67 and accompanying text (discussing the cult of respectability as it developed in the last half of the nineteenth century).

303. See supra notes 55-56 and accompanying text discussing the need for middle-class women to distance themselves from what they regarded as menial household work.

304. See supra note 41 and accompanying text.

305. See supra notes $75-86,93-117$ and accompanying text providing data concerning the labor history of domestic workers in the last half of the nineteenth century.

306. See supra Part II. 
Commissioner. ${ }^{307}$ The taxpayers, Henry and Lillie Wright Smith, claimed a deduction on their 1937 tax returns for, as the court described it, "sums spent by the wife in employing nursemaids to care for petitioners' young child, the wife, as well as the husband, being employed. ${ }^{308}$ One basis for Opper's rejection of the Smiths' claim for a business deduction was that the child-care expenditures were indistinguishable from other types of expenditures, such as medical, clothing, housing, and food. ${ }^{309}$ As the court stated, "but for" any of these types of expenditures, a taxpayer would not be able to earn taxable income. ${ }^{310}$ All of the expenditures that he named represented "the very essence of those 'personal' expenses the deductibility of which is expressly denied."311 Once the court equated child-care expenditures with these other types of expenditures, it found no difficulty in concluding that the petitioners' argument that child-care expenditures enabled the wife to engage in waged labor was unpersuasive.

The reasoning was problematic because it failed to address the problem that, by engaging in waged labor, the petitioners were forgoing the tax benefit of having untaxed imputed income. ${ }^{312}$ As noted earlier, taking into account the untaxed imputed income would not necessarily mean that a deduction should be allowed. ${ }^{313}$ It is fair to say, however, that it makes the case against nondeductibility not as strong as Opper suggested it was. By referring to personal expenditures that did not implicate the issue of imputed income, he obscured inherent problems with both Simons's ideal income definition and with the practical operation of the federal tax system he was applying. ${ }^{314}$

Even more problematic was what Opper had to say about imputed income. Continuing his argument that child-care services were "like similar aspects of family and household life [and are not] other than a personal concern," Opper reasoned that the non-taxability of imputed income was evidence that the expenditure for child-care services was not deductible: ${ }^{315}$ "The wife's services as

307. 40 B.T.A. 1038, aff'd per curiam, 113 F.2d 114 (2d Cir. 1939). For another extensive critique of Smith, see MCCAFFERY, supra note 30 , at 111-14.

308. 40 B.T.A. at 1038 . This case arose before the joint tax retum had been introduced yet both husband and wife were petitioners in the case. The court did not clearly indicate in its opinion whether the deduction was taken on the wife's or husband's tax return or on both their returns.

309. 40 B.T.A. at 1039 .

310. 40 B.T.A. at $1038-39$.

311. See 40 B.T.A. at 1039 .

312. The text adopts the traditional broad definition of imputed income that includes in-kind income produced by one family member for another. If the opinion were analyzed using a narrow definition of imputed income, the court's reasoning could be shown also to have failed to address the problem of having untaxed intrafamily transfers of in-kind service income. See supra notes 243-49 and accompanying text (noting that imputed income is defined to include services provided by one family member for another without any inquiry as to why that is the appropriate result).

313. See supra notes $250-56$ and accompanying text (discussing the interrelationship between the business/personal distinction and imputed income).

314. Had Opper referred to food preparation or dress and shirt making rather than the purchase in the marketplace of food and clothing items an interesting and valuable discussion about where and how to draw the line among different kinds of imputed income from services might have occurred. That difficult problem, however, was obscured completely by Opper's unexamined claim of comparability between expenditures for child-care services and expenditures for medical care, housing, clothing, and food.

315. 40 B.T.A. at 1039. 
custodian of the home and protector of its children are ordinarily rendered without monetary compensation. There results no taxable income from the performance of this service and the correlative expenditure is personal and not susceptible of deduction." ${ }^{316}$ Opper assumed the wife's traditional role of performing reproductive labor without compensation. Although underlying that assumption was a recognition that she was performing valuable services, for and on behalf of, other family members, Opper was unable to break from the conceptual constraints reflected in the public/private distinction. That constraint made him unable to recognize that a wife's household services enabled her husband to enter the waged workforce and produce taxable income. It also seemed to make him unable to appreciate the taxpayers' purchasing of child-care services in the marketplace to enable them to enter the waged workforce as anything other than personal.

Opper understood how the conventional view of imputed income implicated the business/personal distinction in the same way that expenditures $\mathrm{do}^{317}$ What Opper did not appreciate, however, was the potential for tax inequities created by the exclusion of imputed income from the tax base. Opper, when effectively comparing two families with young children-one family in which there were two waged workers and one family in which there was only one waged workershowed no evidence that he recognized the tax inequity. ${ }^{318}$ Instead, he used the comparison to argue that the non-taxability of child-care services performed by a wife for her own children was a reason not to allow a deduction for child-care expenditures. ${ }^{319}$ Had he raised concerns about taxpayers without young children in need of child-care services, his argument about the personal nature of the child-care expenditures would have been more understandable. ${ }^{320}$ Apparently, he was not prepared to discuss the decision to have children as a personal (nonbusiness) choice. Instead, he preferred to show the personal nature of the expenditures by focusing on the wife's choice to enter the waged labor market.

Here the wife has chosen to employ others to discharge her domestic function and the services she performs are rendered outside the home. They are a source of actual income and taxable as such. But that does not deprive the same work performed by others of its personal character nor furnish a reason why its cost should be treated as an offset in the guise of a deductible item. ${ }^{321}$

Focusing on the wife's choice to perform child-care services for the family or

\footnotetext{
316. See id.

317. See id.

318. See id.

319. See id.

320. See supra notes $253-56$ and accompanying text (analyzing the business/personal distinction and imputed income by comparing various family situations).

321. 40 B.T.A. at 1039.
} 
purchase them from another was both different from and similar to the reasoning found in Simons. ${ }^{322}$ Like Simons, Opper recognized that the wife is engaged in waged work-he analyzed the tax situation of a lady-like worker and not that of a lady. ${ }^{323}$ Unlike Simons, however, he saw the decision to employ others to perform her household duties as personal and unconnected to the waged labor she was performing. ${ }^{324}$ The result of that reasoning was that, under the guise of objective tax analysis, the cult of respectability and the hierarchical relations on which it relies were strengthened.

The other basis for the court's holding in Smith that child-care expenditures are not deductible was tradition. The petitioners had argued that working wives were "a new phenomenon." ${ }^{25}$ Opper's response was that a social and economic change of this type made it "all the more necessary to apply accepted principles to the novel facts."326 The petitioners addressed the "accepted principles" arguments by echoing a recurrent theme in Simons's writings that "[a] thoroughly precise and objective distinction [between business and personal] is inconceivable." 327 They reminded the court that "disbursements normally personal may become deductible by reason of their intimate connection with an occupation carried on for profit. ${ }^{\prime 328}$ Rather than acknowledge the indeterminacy of the tax code with regard to the business/personal distinction, Opper declared tradition to be an accepted principle and then went on to assert that tradition required child-care expenditures to be nondeductible: ${ }^{329}$

The line is not always an easy one to draw nor the test simple to apply. But we think its principle is clear. It may for practical purposes be said to constitute a distinction between those activities which, as a matter of common acceptance and universal experience, are "ordinary" or usual as the direct accompaniment of business pursuits, on the one hand; and those which, though they may in some indirect and tenuous degree relate to the circumstances of a profitable occupation, are nevertheless personal in their nature, of a character applicable to human beings generally, and which exist on that plane regardless of the occupation, though not necessarily of the station in life, of the individuals concerned....

In the latter category, we think, fall payments made to servants or others occupied in looking to the personal wants of their employers. . . And we include in this group nursemaids retained to care for infant

322. See id.

323. See id.

324. See id.

325. Id.

326. Id. (emphasis added).

327. SIMONS, supra note 13, at 54. See supra text accompanying notes 233-35 (discussing Simons's theme of inconceivable preciseness).

328. 40 B.T.A. at 1039.

329. See id. at 1039 . 
children. ${ }^{330}$

Relying on social norms, Opper easily ignored, or at least was easily indifferent, to the gendered tradition of the public/private distinction upon which he relied. ${ }^{331}$ Childcare occurred at the hearth and it was beyond reason apparently from Opper's vantage point to suggest, as the petitioners were doing, ${ }^{332}$ that it could shift to the business side of the business/personal distinction.

One also might detect that issues concerning class differences influenced the court in Smith to deny a deduction for child-care expenditures. Opper's reference to a person's "station in life" and "servants" meeting the "personal wants of their employers" suggests that he viewed the hiring of a child-care worker ("nursemaid") as a luxury available only to the upper class. ${ }^{333}$ With a few ambiguous references, we can only speculate that Opper viewed the deduction for child-care expenditures as operating to the unfair advantage of the wealthy. Perhaps he believed that well-to-do taxpayers would be the most likely to hire a "nursemaid" to meet child-care needs. Perhaps he believed that the less wealthy working class would meet those needs by relying on non-market arrangements (in-kind service income) of extended family members, such as grandmothers and aunts, or even older children. Although both would have enjoyed the advantage of lower tax liabilities (the wealthy through a deduction from income; the less wealthy through income exclusion if they had to pay any tax at all), achieving tax equity by increasing the deductions available to the wealthy may have nevertheless seemed untenable. This might have seemed especially true within the social and economic environment of the Great Depression in which Opper was writing. ${ }^{334}$

Whatever the extent of Opper's liberal instinct to preserve the progressive tax by finding child-care expenditures nondeductible, the idea that childcare and other reproductive labor were women's private responsibility even if women could avoid that responsibility by hiring other women to do it, was left intact.

330. Id. at 1039-40 (emphasis added)

331. See supra notes $45-49$ and accompanying text (discussing the public/private distinction).

332. See 40 B.T.A. at 1039.

333. 40 B.T.A. at 1040. A related point of interest is that Henry Smith was an attorney who himself argued the case before Opper.

334. The approach that has been taken in the child-care tax provisions since it was first enacted in 1954-favoring parents in the lower-tax brackets over those in the higher-tax brackets-reflects a similar type of class analysis of employment-related child-care expenditures that is only hinted at by Opper. In fact, the debate over the 1954 enactment, that occurred in the vastly different postwar period and over fifteen years after the Smith decision, reflected concerns similar to those that may have been troubling Opper. One of the most notable concerns was that middle-class women entering the waged labor market were doing so for personal reasons and that the child-care expenditures might be of a quality and cost beyond that necessary to engage in waged labor. See supra notes 161-63 and accompanying text (discussing the legislative history accompanying the 1954 legislation). The Smith case and the debates surrounding the 1954 enactment allowing the deduction for child-care expenditures provide a good example of how the government defers to the judgment of the taxpayer when the expenditures are presumed to be business-related while the government subjects expenditures presumed to be personal to substantial regulation and skepticism. See Roy, supra note 232, at 188-89. 
The marketplace transactions of hiring the child-care worker and entering the waged workforce are ignored. What might first appear to be a hint of genuine class sympathy, therefore, becomes on closer examination a reinforcement of class, gender, and racial hierarchies. For Opper, the mother and wife remain the ideal, and history tells us that the ideal of the lady can only be achieved through class, gender, and race subordination.

Although Opper's opinion is more a series of unsupported conclusions than it is reasoned analysis, it is not surprising given its historical underpinnings that it has continuing influence in maintaining the view that sound tax principles do not support the deductibility of child-care expenditures. Not even the fact that Congress ultimately overrode the Smith decision by enacting a child-care provision seems to have mattered. One significant reason why Smith has had such a long-lasting influence is that its conclusions were reinforced nearly thirty years later within the analytical framework of the tax expenditure budget, which Stanley Surrey successfully promoted.

\section{Stanley Surrey: The Tax Expenditure Budget}

In 1967, Stanley Surrey made a speech in his capacity as Assistant Secretary of the Treasury for Tax Policy in which he developed the concept of "tax expenditures" and a "tax expenditure budget." ${ }^{\text {"35 }}$ Surrey understood the federal income tax system as consisting of two types of provisions. One type are those "structural provisions necessary to implement the income tax on individual and corporate net income." ${ }^{\text {"336 }}$ The other type are those provisions that "comprise[ ] a system of tax expenditures under which the Governmental financial assistance programs are carried out through special tax provisions rather than through direct Government expenditures. ${ }^{337}$ The term tax expenditures was chosen to indicate that these provisions are the equivalent of direct government outlays, the only difference being that they are accomplished through the federal income tax system. ${ }^{338}$ Surrey's purpose for classifying tax provisions as either structural or tax expenditures was to expose the relationship between tax reform and Government expenditures and to suggest "new pathways to tax reform." 339 For him, tax reform meant grappling with questions, such as, "[ [] s tax assistance the preferred route, or should the assistance be given directly? Which method comes closest to the targeted goal of the assistance and does so with fairness and efficiency? ${ }^{340}$

The business/personal distinction and imputed income issues are incorporated into the structural/tax expenditure distinction. As Surrey acknowledged, the tax

\footnotetext{
335. SURREY, supra note 15 , at 3

336. Id. at 6 .

337. Id.

338. See id. at 3.

339. Id at viii-ix

340. Id. at viii.
} 
expenditure budget raises "difficulties in the application of agreed income tax structural concepts, such as the proper line between allowable expenses incurred in trade or business or in the acquisition of income and nondeductible personal consumption expenses (e.g., moving expenses or child care expenses)....,341 That acknowledgment, however, did not lead him to modify his approach to account for the difficulties. ${ }^{342}$

Surrey was more concerned about items being omitted from the list of tax expenditures than he was about those that were included. ${ }^{343}$ That made logical sense within his proposal because being listed as a tax expenditure purportedly meant that the item would be subject to political scrutiny. At that point, any arguments about difficulties of classification between business and personal could be made. What Surrey failed to acknowledge, however, were the practical difficulties of successfully challenging the classification of any one item. Once the tax treatment (a deduction initially and subsequently a credit or exclusion) for employment-related child-care costs was classified as a tax expenditure, especially given the historical construction of reproductive labor within our social and economic institutions, including the tax law, it is no surprise that no serious consideration has been given to reclassifying the tax treatment.

Even Surrey, who had listed childcare as an example of the type of expenditure that raised definition problems, ${ }^{344}$ ignored those difficulties when addressing the question of whether child-care expenditures should continue to be deductible under the federal income tax system. ${ }^{345}$ Surrey put the deduction for child-care expenditures among a group of tax expenditure items that should be eliminated and replaced by direct financial assistance from the government. ${ }^{346}$ He reasoned that the provision was introduced into the tax system at a time when there were few governmental child-care programs. ${ }^{347}$ With the increased availability of programs for childcare in the 1970s, he believed it was appropriate to have the tax provision eliminated and the tax savings channeled to those existing programs. ${ }^{348}$ The primary advantage he saw to using direct assistance was that it would allow the funds to be used for those families who

341. Id. at 19 (emphasis added).

342. The Tax Expenditure Budget continues to classify the tax provisions for dependent care expenses as tax expenditures. See JOINT COMM. ON TAXATION, supra note 11, at table 1.

343. See SURREY, supra note 15 , at 19.

344. See id.

345. See id. at $\mathbf{1 9 8 - 2 0 2}$

346. See id.

347.

Its presence in the tax system reflects the earlier absence of direct child care programs available to a family where both spouses were employed ... . Tax expenditure items of this character evidence the sensitivity of the tax system to concem over the lack of federal assistance in social areas. Relief through the tax system is thus the point where social advance wedges into the federal budget and is often the forerunner of larger and more adequate direct programs in later years. Unfortunately, the Id. at 201 . tax expenditure item usually remains as an inequitable and vestigial program.

348. See id:; see also supra notes 175-79 and accompanying text (discussing child-care legislation in the 1960 s and 1970s). 
were "poor" and who could not take advantage of the tax provision, thus reducing the benefits going to families with higher incomes. ${ }^{349}$ This argument is a variation on the "upside-down" subsidy theme that Surrey emphasized throughout his discussion of the tax expenditure model. ${ }^{350}$ After making the observation that a tax deduction provided under a progressive tax system leads to greater tax benefits for the wealthy because a deduction is worth more to those persons who have greater incomes and, therefore, are taxed at higher rates, ${ }^{351}$ Surrey contended that "almost any of these tax expenditures is seen as woefully unfair or inefficient when cast as a direct expenditure program." 352

Surrey bolstered his redistribution argument by focusing on the greater effectiveness of child-development programs stressed in the direct assistance programs as compared to the simple custodial care required under the tax provision. ${ }^{353} \mathrm{He}$ saw this issue as directly related to his redistribution argument when he cited the Senate Finance Committee's decision in 1971 to allow a deduction for household expenditures unrelated to childcare once the taxpayer otherwise qualified for a deduction under the tax provision. ${ }^{354} \mathrm{He}$ indicated that the Committee saw this "reform" as part of the government's larger efforts "to take people off welfare." ${ }^{.355}$ It cannot be doubted that Surrey found subsidies to employers of persons who perform domestic work for them misguided and contrary to what should be the redistributive policies of the federal government. He wrote:

But there is a strange irony in giving tax benefits to upper middle class families to aid them in employing servants to help solve welfare problems. It is clear that no direct program of this characterGovernment grants to better-off families to subsidize their obtaining domestic help - could stand the light of public scrutiny. But here it is, buried in the child care tax expenditure. This is another illustration of how one tax expenditure program, itself dubious, expands to encompass additional programs that are even more ill-advised. ${ }^{356}$

Surrey's line of argument concerning welfare, direct subsidies for childcare, and persons who are poor ${ }^{357}$ was made in the context of the civil rights movement,

349. See SURREY, supra note 15, at 201-02.

350. See id. at 37 .

351. See id. at 36 .

352. Id. at 37. But see Griffith, supra note 269 , at $352-63$ (providing alternative analyses of the distributive implications of tax expenditures); Handelman, supra note 231 , at 123 ("[T]ax expenditure analysis reflects unacknowledged, and surely unintentional, class bias. Higher-income taxpayers are the principal beneficiaries of . . prudential adjustments to the definition of income. The experiences and perceptions of working people are not taken similarly into account.").

353. See SURREY, supra note 15, at 202.

354. See id; see also supra notes $182-86$ and accompanying text (discussing this tax change).

355. SURREY, supra note 15 , at 202.

356. Id

357. See id. 
Operation Headstart, and the War on Poverty. ${ }^{358}$ As noted earlier, in the late 1960 s and early 1970 s, childcare became inextricably linked to race as well as class. ${ }^{359}$ Therefore, his critique based on the progressivity principle also should be understood as a critique of the racial bias that motivated proposals to expand the availability of tax benefits for child-care expenditures as well as limit direct funding programs.

Although Surrey came close to embracing the antisubordination principle I am advancing, his analysis fell short. He assumed that, if the tax law eliminates a deduction for childcare, it is no longer complicit in facilitating economic exploitation and racism. He neither saw how tax neutrality could constitute complicity in exploitative and subordinating practices nor imagined how the tax law might take a more active role in disrupting those practices.

Surrey's redistribution arguments are also problematic because they implicitly assumed that child-care expenditures are personal rather than business and ignored the imputed income implications raised by child-care expenditures. Surrey took up both these aspects of child-care expenditures in a footnote ${ }^{360}$ Again referring to the debates in 1971 surrounding the child-care tax provision, he noted that "there was an unsuccessful effort to convert it into a deduction that determined adjusted gross income rather than an itemized deduction in the deduction group alternative to the standard deduction." ${ }^{\text {"361 }} \mathrm{He}$ went on to say that the proposal was based on the argument that child-care expenditures were like other business expenses. ${ }^{362}$ Surrey viewed this argument as gendered, and believed that once he removed gender from the argument the personal nature of the expense would become clear:

Much of the force behind the position that childcare is a real business expense derives from the view of women's groups that the expense of child care is generally offset against the working wife's probable earnings to see how much net income she would add to the family by working. Under these mores, the child care deduction assists her in obtaining a freedom of decision on a parity with the husband. . . In this view, it would seem that if decisions as to who works outside the home were made regardless of sex, there would be no basis for the child care deduction. If so, as a matter of tax structure it is hard to see why the expense is really a business expense and not a personal expense. What steps Congress should take to assist in altering current mores regarding women and career occupations is a matter for direct expenditure

358. See supra notes 175-77 and accompanying text (discussing the federal domestic legislative agenda during the middle and late 1960s).

359. See supra notes 175-77 and accompanying text (discussing Operation Headstart and how it came to be socially and politically understood).

360. See SURREY, supra note 15 , at 357 n. 66

361. Id.

362. See id. 
programs, such as those for child care and development assistance, and not tax programs. ${ }^{363}$

Surrey's reasoning with regard to the business/personal nature of child-care expenditures is perplexing. He did not explain why it was important to resolving the business/personal issue that the proposal was made by women's groups. ${ }^{364}$ Even more problematic is how he used the fact that the limitations on deductibility of child-care expenditures had their greatest practical effect on women entering the work force as a basis for reasoning that child-care expenditures were personal. ${ }^{365} \mathrm{He}$ seemed to understand this argument as an argument about sex discrimination rather than as an argument showing that child-care expenditures enabled the earning of income by both parents when he stated that "it would seem that if decisions as to who works outside the home were made regardless of sex, there would be no basis for the child-care deduction." ${ }^{366}$ However one might interpret his response to the proposal, it is hard to avoid the conclusion that Surrey believed that any effort to address sex discrimination in employment was beyond the appropriate goals of the tax system.

In this same footnote, Surrey addressed issues related to imputed income. ${ }^{367}$ Apparently, he felt that more needed to be said once the comparison between one-waged-worker and two-waged-worker families was raised ${ }^{368}$ His reasoning about imputed income is most intriguing, especially in view of Simons's position on imputed income from services. ${ }^{369}$ Surrey wrote:

Of course, if the imputed income of a family member staying home and providing child care and household services were taxed, then tax differences in this respect between that member working or staying at home would not exist; also there should be no deduction for amounts paid to others for child care and household services. This view then shifts the argument to whether a child care deduction is appropriate to offset the non-taxation of such imputed income. But tax measures having this function would seem to be properly classed as tax expenditures, and to be judged accordingly. ${ }^{370}$

363. Id. See supra note 265 for cases challenging constitutionality of child-care provisions based on gender.

364. See SURREY, supra note 15 , at 357 n. 66 .

365. See id.

366. Id.

367. See id.

368. See id

369. For a discussion of Simons's position on imputed income from services, see supra notes 271-73 and accompanying text.

370. SURREY, supra note 15 , at 357 n.66. This passage makes clear that Surrey embraced the conventional broad definition of imputed income, which means that he ignored the tax implications of intrafamily transfers of in-kind income for services. See supra notes 243-49 and accompanying text noting that imputed income is defined to include services provided by one family member for another without any inquiry 
One's first reaction to Surrey's response to the inequity created by the nontaxability of imputed income from services may be dismay. ${ }^{371}$ If assuring horizontal equity-treating similarly situated families similarly under the tax system - is not a tax structural provision, it becomes harder to understand what would be. His response only makes sense within the context of the ideal accretion tax and the Haig-Simons definition of income, which underlies the Tax Expenditure Budget. ${ }^{372}$ Simons ignored imputed income from services. Therefore, Surrey apparently reasoned that any provision designed to address that issue becomes a tax expenditure. ${ }^{373}$ Although technically sound, Surrey's conclusion ultimately raises serious questions about how useful the Tax Expenditure Budget can be as a basis for tax reform. ${ }^{374}$

Surrey clearly drew on his liberal instincts to inform his tax analysis. His conclusions, however, coincided with the gendered tradition that reproductive labor, and childcare in particular, were the primary responsibility of women to be accomplished by the upper and middle classes within the private domain without direct or indirect governmental assistance. In what appears to be an unintended effect of Surrey's analysis, concerns about subordination based on class, gender, and race become the basis for arguing that a tax response is inappropriate rather than a reason to explore how tax reform might disrupt it.

\section{Summary}

An analysis of the approaches used by Simons, Opper, and Surrey addressing the question of the deductibility of child-care expenditures shows that they are all quite similar. All three acknowledged the difficulty of developing objective guidelines to distinguish between business and personal expenses, and all three failed to confront this difficulty when reaching the conclusion that child-care expenditures should not be deductible. Although Surrey was more explicit and Simons was less direct on this question, all three understood this deduction as disproportionately benefiting higher-income families. All three relied on traditional gender roles as they each strove to achieve the appearance of applying tax principles objectively for the purpose of approximating an ideal income tax base. Within that tradition, all three failed to consider the effect of nondeductibility of child-care expenditures on child-care workers.

The approaches of Simons, Opper, and Surrey differ most with regard to issues of race. Simons reinforced racial stereotypes with his implicit reference to

as to why that is the appropriate result.

371. See SURREY, supra note 15 , at 357 n. 66 .

372. See id at 12-13.

373. See supra notes 271-73 and accompanying text (discussing Simons's position on imputed income from services)

374. See Griffith, supra note 269 , at $346-47$ (critiquing the modifications to Haig-Simons that the tax expenditure model makes, such as ignoring the non-taxation of unrealized appreciation in property and the exclusion from income of imputed income from owner-occupied homes and other property). 
the cult of respectability. Opper treated race as invisible; based exclusively on the historical treatment of reproductive labor and waged household workers, his reasoning left racial and ethnic hierarchies in place. Although Surrey implicitly acknowledged race discrimination in his analysis of Congressional treatment of childcare in the early 1970s, it is clear that all three, including Surrey, saw racial hierarchies beyond the purview of an ideal income tax base.

Scrutiny of their respective approaches demonstrates that each failed to provide a convincing rationale either for or against deductibility of child-care expenditures. Each refused to consider the implications of having a tax system in which reliance on so-called objective principles could not produce predictable results. Instead, each arranged their arguments in such a way as to perpetuate the myth that an income tax system consists of predetermined objective principles.

The perpetuation of that myth has had considerable influence on tax commentators addressing the question of the proper tax treatment of child-care expenditures. Some commentators remain tied to the business/personal distinction and marshal a variety of arguments in favor of treating child-care costs as a business expense in the tax law. ${ }^{375}$ In contrast, others assume that the deduction for child-care costs is a tax expenditure and argue that this deduction should be retained or expanded under the tax law. ${ }^{376}$ The nature of the child-care debate can be transformed, however, by introducing the antisubordination principle into tax policy discourse. The proper measurement of the income tax base of taxpayers who employ child-care workers is no longer the only issue. As we have seen, an examination of the historical context of childcare changes the discourse by expanding the range of relevant tax issues to include questioning the effects of tax law on child-care workers. That analysis is undertaken in Part V.

\section{EMPLOYMENT-RELATED CHILD-CARE EXPENDITURES UNDER THE TAX LAW: APPLYING THE ANTISUBORDINATION PRINCIPLE}

Supplementing a discussion of the business/personal distinction and the concept of imputed income with a historical analysis of class, gender, and race in the child-care labor market leads to a reevaluation of current tax law provisions. On the one hand, the tax rules for employment-related child-care expenditures provided under sections 21 and 129 suggest an acknowledgment of the business

375. For examples of commentators showing child-care costs to be an appropriate business deduction, see ABA Section on Taxation, supra note 7, at 341; Marjorie Kornhauser, Theory Versus Reality: The Parinership Model of Marriage in Family and Income Tax Law, 69 TEMP. L. REV.1413, 1447-48 (1996); Zelenak, supra note 6, at 409-11; Lawrence Zelenak, The Reification of Metaphor: Income Taxes, Consumption Taxes and Human Capital, 51 TAX L. REV. 1, 14 n.60 (1995); Ellen R. Zieve, To Work or Not to Work, and What about the Kids?, 3 S. CAL. REV. L. \& WOMEN's STUD. 163, 167-76, 181 (1993).

376. See, e.g., Michael Livingston, Risky Business: Economics, Culture and the Taxation of Highrisk Activities, 48 TAX L. REV. 163, 184 n.74 (1993) (explaining provisions as reflecting cultural values); John F. Witte, Congress and Tax Policy: Problems and Reforms in a Historical Context, 10 AM. J. TAX POL'Y 107, 113 (1992) (explaining child-care provisions along with others as part of a dynamic of "tax politics"). 
nature of these expenditures. On the other hand, the segregation of child-care expenditures from other employee-related or self-employed expenditures suggests their personal nature. This view is reinforced by the structure of the credit calculation under section 21. By circumventing the progressive rate structure to allow for greater reductions in tax liability for lower-income taxpayers than for higher-income taxpayers, the credit appears more related to redistribution of wealth concerns than determining the appropriate tax base under an ideal accretion tax. Arguably, the conflicting interpretations of the tax provisions appropriately reflect the ambiguity inherent in the business/personal distinction. Even though the reasoning found in Simons's Personal Income Taxation, the Smith case, and Surrey's Pathways to Tax Reform resisted the implications of the "inescapable" problems of the business/personal distinction, in the political arena, where ambiguity and compromise are coins of the realm, the idea of an expense having both a business and personal nature appears to have found support.

The historical devaluation of reproductive labor adds another dimension to the business/personal controversy surrounding employment-related child-care expenditures. For expenditures where the distinction between business and personal is otherwise difficult to make, arguably the tax law should err on the side of classifying an expenditure as business related. Treating an expenditure, such as childcare, the same as other business deductions would disrupt the hierarchical distinction between productive and reproductive labor. By treating child-care expenditures as personal, the tax law perpetuates the economic exploitation, sexism, and racism that is rationalized by distinguishing between public production and private reproduction. Reconnecting the business/personal distinction to its social, cultural, and economic roots makes the limited tax relief provided under sections 21 and 129 seem inadequate.

Another reason for favoring a deduction that is not limited either by the income level of the taxpayer or the amount spent for employment-related childcare concerns the tax inequity created by the exclusion of child-care services, performed in the home by parents, from the tax base, and the class, gender, and race implications of that exclusion. Recent statistics show that the percentage of married couples with children in which both parents work exceeds seventy percent for couples with children over age six and is nearly sixty percent for couples with children under age six. ${ }^{377}$ Considering the increasing number of single mothers, we can conclude that the great majority of taxpayers do not enjoy the tax benefit of excluding child-care services performed by a parent. ${ }^{378}$ Arguably, these statistics suggest that the exclusion creates only minor issues of tax equity because of the ever-increasing rates of two-income couples and single

377. See supra note 145

378. In $1995,65 \%$ of all "never married" women with children were in the waged labor force and $57 \%$ of all women with children who had been widowed, divorced, or separated were in the waged labor force. See Nantell, supra note 11, at 883-84. 
mothers.

The antisubordination principle, however, encourages us to look in more detail at who is most likely to accrue the benefits of tax-free imputed income. ${ }^{379}$ Data on earnings suggest that the substantially higher salaries and wages paid to white married men places them in a better financial position to forgo their wives' waged earnings and enjoy the tax-free benefits of her child-care services. ${ }^{380}$ These statistics suggest that excluding child-care services from income has significant class and race implications. By allowing a deduction for child-care expenditures, the tax law indirectly taxes the child-care services enjoyed by oneearner couples. ${ }^{381}$ An unlimited deduction would indirectly ameliorate some of the effects of wage and salary discrimination experienced by women and men of color in all sectors of the labor market. Yet another consequence of providing an unlimited deduction for child-care expenditures would be the removal of one potential economic barrier for women entering the waged labor market. The income exclusion encourages women to remain in the household, giving continuing vitality to the cult of respectability.

The arguments just presented for an unlimited child-care deduction demonstrate how the integration of antisubordination principle into an analysis of the business/personal distinction and conventional notions of imputed income can change the character of those common staples of tax analysis. The antisubordination principle transforms seemingly objective criteria by reconnecting them with various social and economic institutions. The veil of objectivity surrounding traditional tax principles is lifted once the historical context from which they were derived and operate is revealed.

The foregoing analysis remains woefully incomplete because it only indirectly addresses the issue of economic exploitation of child-care workers. Over time, and in combination with the successes of other social movements, the sociopolitical devaluation of reproductive labor and related discriminatory wage patterns could be countered by an unlimited child-care deduction. In the context of the social, political, and economic trends today, however, this proposal seems like nothing more than the substitution of one set of abstractions (the business/personal distinction, imputed income, and the ideal accretion tax) with another set (productive/reproductive labor distinction, the public/private distinction, and stratified reproduction).

The primary problem with the proposal is that it ignores what we know about

379. The text reference to imputed income is based on the traditional definition of imputed income, which includes in-kind income produced by one family member for another. If a more narrow definition of imputed income is adopted, the tax equity issue raised in the text would include not only the exclusion of inkind income from child-care services individuals produce for themselves, but also the exclusion of intrafamily transfers of child-care services. See supra notes 243-49 and accompanying text (noting that imputed income is defined to include services provided by one family member for another without any inquiry as to why that is the appropriate result).

380. See supra notes $146-47$ and accompanying text (referring to data showing the relative incomes of married men based on race).

381. See supra note 255 and accompanying text. 
today's child-care labor market. Wages for child-care workers are depressed and, in view of the elasticity of the labor supply, are not likely to increase, even with increased tax benefits for child-care consumers. ${ }^{382}$ Any increase in tax benefits are far more likely to accrue to the consumers of childcare than they are to trickle down to child-care workers through increased wages and benefits or improved working conditions.

One response to this problem might be that an unlimited child-care deduction be accompanied with increased enforcement of federal and state labor laws and federal immigration laws to address directly problems in the child-care labor market through governmental intervention. The current subsidy to the middle class through the "seepage of unauthorized workers"383 into childcare is indefensible. ${ }^{384}$ Linking an expansion of the child-care deduction that is likely to benefit the child-care consumer to other labor and immigration policies, however, without first changing the underlying structures supporting those policies would seem to betray any commitment to take seriously the economic exploitation and racism experienced by migrant household workers.

Another response might be the elimination of any tax relief for employmentrelated child-care expenditures. The tax savings from such a measure, projected in 1997 to have been approximately $\$ 3.6$ billion, ${ }^{385}$ could be used to design child-care programs that could simultaneously increase the availability of affordable care to lower-income taxpayers and upgrade the working conditions and wages for child-care workers. One problem with this response is that the loss of tax relief may increase the incentives for middle-class families to obtain childcare services through the underground economy. Although there is no evidence that increased tax relief will lead to higher wages or better working conditions for child-care workers, neither is there assurance that the removal of tax benefits will not detrimentally affect the workers.

The 1996 welfare reform legislation mandates work participation rates by recipients of benefits. ${ }^{386}$ As part of this legislation, the federal government

382. This analysis relies on the work of A.C. Pigou, who supported the use of tax to correct market failures. See generally A.C. PIGOU, A STUDY IN PUBLIC FINANCE (3d ed. 1947). For further discussion of the relation of Pigou's work to the treatment of child-care expenditures, see Mary L. Heen, Welfare Reform, Child Care Costs, and Taxes: Delivering Increased Work-Related Child Care Benefits to Low-Income Families, 13 YALE L. \& POL'Y REV. 173, 208-09 (1995) (viewing the market failures as having to do with parents' and society's failure "to invest adequately in children's human capital" and the "constellation of . . . social and economic factors discouraging women from full labor force participation.")

383. Papademetriou, supra note 203 , at 28 .

384. Some might argue that stricter enforcement of immigration laws might be detrimental to the childcare workers because it would create further barriers to their ability to earn a living. This response is problematic because it fails to take into account the history of migrant labor in this country and becomes an excuse for exploitation. See supra notes 68-117, 204-25 and accompanying text (discussing the history of migrant workers providing domestic services, and specifically child-care services, during the late nineteenth century and throughout the twentieth century)

385. See JONT COMM. ON TAXATTON, supra note 11 , at table 1 .

386. See Personal Responsibility \& Work Opportunity Reconciliation Act of 1996, Pub. L. No. 104-193, 110 Stat. 2105 (codified as amended in scattered sections of 42 U.S.C.); Center for Law \& Social Policy, The Temporary Assistance for Needy Families Block Grant, 4 GEO. J. FIGHTING POVERTY 311, 311-13 (1997); Mark Greenberg, HHS Policy Guidance on Maintenance of Effort, Assistance, and Penalties: Summary and 
provides block grants to the states for childcare ${ }^{387}$ A portion of the child-care grant money is available only if the state meets certain matching requirements. ${ }^{388}$ Predictions are that the new dollars for childcare fall far short of what would be needed to implement the new work requirements. ${ }^{389}$ Not only does this new legislation undermine the availability, affordability, and quality of childcare for low-income families, it also casts doubt on the federal and state governments' commitment to assuring fair working conditions for child-care workers. Rather than seeing the recent changes in welfare laws as invigorating a commitment of federal and state governments to provide quality childcare, state and federal governments, under the cover of fiscal responsibility, may ultimately place considerable pressure on child-care workers to keep their compensation low.

Appeals to fiscal responsibility may also be a reason why an unlimited deduction for employment-related child-care expenditures may be unlikely to prevail. Nevertheless, the experience over the last four decades suggests that tax reform related to childcare is more likely to gain legislative support than direct funding programs. Its appeal to the politically powerful middle class may be enough at some point in the future to lead policymakers to reorder their fiscal priorities. ${ }^{390}$

The question then arises as to what kind of tax reform could avoid the reinforcement of class, gender, and race hierarchies identified with the current approach and simultaneously disrupt the economic exploitation of child-care workers. Two reforms warrant serious consideration in any discussion of the tax treatment of employment-related child-care expenditures. One would entail a direct response to the issue of economic exploitation of child-care workers by abandoning the idea of an unlimited deduction and allowing instead employment-related child-care expenditures to be deducted only for those childcare expenditures that exceed some percentage of the taxpayer's adjusted gross income. For example, assuming a percentage limitation of five percent, if $T$ had adjusted gross income of $\$ 75,000$ and employment-related child-care expenditures of $\$ 5,000, T$ would be allowed to deduct $\$ 1,250(\$ 5,000-(\$ 75,000$ $\mathrm{x} .05)$ ). The amount the taxpayer spends on childcare becomes the tool by which the tax law intervenes into a sector of the labor market that is economically

Discussion, 4 GEO. J. FIGHTING POVERTY 315, 319 (1997); Nichola L. Marshall, The Welfare Reform Act of 1996: Political Compromise or Panacea for Welfare Dependency, 4 GEO. J. FightING POVERTY 333, 335 (1997).

387. See Center for Law \& Social Policy, supra note 386, at 312.

388. See id.

389. See Congressional Budget Office, CBO Memorandum: Federal Budgetary Implications of the Personal Responsibility and Work Opportunity Reconciliation Act of 1996, at 13 (Dec. 1996) (estimating a $\$ 1.4$ billion shortfall for 1997-2002); see also CHILDREN's DEFENSE FUND, THE STATE OF AMERICA's CHILDREN: YEARBOOK 1997, at 35-38 (1997) (describing unmet need of child-care assistance for low-income working families and the inadequate funding of child-care assistance for parents forced into the work force under the 1996 law). But see Jason DeParle, The Welfare Evolution: A Special Report, N.Y. TIMES, June 30, 1997, at Al (reporting that states are doing more than was expected regarding expanding eligibility for childcare programs and allocating resources to child care)

390. See supra notes $182-86$ and accompanying text discussing changes to the tax treatment of employment-related child-care expenditures during the 1970 s that favored middle-class families. 
exploitative due to class, gender, and race subordination. ${ }^{391} T \mathrm{~s}$ expenditures on child-care services in excess of a minimum amount would be fully deductible. Keying the amount deductible to the taxpayer's adjusted gross income ameliorates, to some extent, the problem that an unlimited deduction would disproportionately benefit higher-income taxpayers. ${ }^{392}$ If the reform were to achieve its dual goal of addressing the needs of consumers and providers in the child-care market, the revenue loss could be as high as would result from the adoption of an unlimited child-care deduction. Any revenue savings produced by the limitations should be offset by increased costs of childcare resulting from improved working conditions and higher wages for child-care workers.

One criticism of denying a deduction for some portion of child-care expenditures incurred is that it undermines the benefits otherwise achieved by having the tax law unambiguously treat employment-related child-care expenditures as a business expense. Although the motivation for the limitations are quite different, the limitations for child-care expenditures would resemble the limitations placed on other controversial deductions, such as medical expenses and casualty losses. ${ }^{393}$ Perhaps one way to counteract this perception is to allow the deduction to be taken to reach adjusted gross income so as to distinguish it from other deductible expenses viewed as personal in nature. ${ }^{394}$

Another criticism is that consumer expectations and the general view of the economic worth of child-care services will combine to make the availability of the tax deduction irrelevant. Instead of encouraging consumers to increase the wages and improve the working conditions of child-care workers, it may lead to increased reliance on the underground economy. The history of the child-care labor market certainly suggests that consumer resistance will be strong. Whether it is possible to overcome that tradition by setting a standard of fair wages through the tax law is unknown. To design a tax provision that ignores the reality of economic exploitation in this labor market, however, seems wholly unacceptable.

Some of the concern about consumer resistance could be addressed through an additional reform that would work in conjunction with the first. This reform

391. To avoid the possibility that child-care consumers might further exploit child-care workers and intensify the racial divisions within child-care services by entering into secondary child-care arrangements, some type of constraint under either type of reform needs to be placed on the deduction based on the number of child-care workers hired. See supra note 211 (discussing secondary child-care arrangements).

392. To meet further the needs of low-income taxpayers who incur employment-related child-care expenditures consistent with encouraging fair wages and working conditions for child-care workers, the proposal could include a refundable tax feature. That would mean that taxpayers who would otherwise not owe any taxes would nevertheless receive a tax refund based on the amount of child-care expenditures they had incurred. For further discussion of refundability, see Nantell, supra note 11, at 937-38, 949.

393. See I.R.C. $\S \S 165(h)$ (casualty losses); 213 (medical expenses); William D. Andrews, Personal Deductions in an Ideal Income Tax, 86 HARV. L. REV. 309, 331 -43 (1972) (medical expenditures); Epstein, supra note 263, at 463-67 (casualty losses); see generally Stanley A. Koppelman, Personal Deductions Under an Ideal Income Tax, 43 TAX L. REV. 679 (1988) (analyzing the relationship of income definition to personal deductions that includes consideration of casualty losses and medical expenses)

394. This would, of course, require the amount to be determined on the basis of a tentatively computed adjusted gross income amount. 
entails two substantial amendments to section 129. The first change would be to eliminate the limitation on the amount of child-care assistance employers are allowed to provide for their employees. The other change would be to allow the employee to exclude the in-kind or reimbursed amounts from income only if the employer assures that the child-care workers' working conditions meet certain criteria, such as a fair salary, reasonable working hours, and provision for family health care. The exclusion provided under section 129, as amended, would be more valuable to an employee than the limited deduction proposed above because the amount of the exclusion would not depend on an employee's adjusted gross income. ${ }^{395}$ This difference would encourage employers to establish child-care assistance programs. One major advantage of employerprovided child-care assistance is that high standards of care by, and working conditions for, child-care workers are more likely to be achieved. The government can assure proper working conditions for child-care workers far more easily through IRS audits of employers of child-care consumers than it can by trying to regulate the child-care market by investigating individual child-care workers and consumers. By creating tax incentives for employers to provide quality child-care assistance programs, current conditions in the child-care market can be changed dramatically, benefiting both child-care consumers and child-care workers. ${ }^{396}$

A second major advantage of employer-provided child-care assistance is that it would acknowledge employers' partial responsibility for the well-being of their workers' families. ${ }^{397}$ The historical tradition of viewing childcare as private has not only supported the production/reproduction hierarchy, but has also obscured the relationship of childcare to production itself. Tax incentives for employerprovided childcare will encourage the marketplace to recognize its coresponsibility for the care and nurturing of young generations who represent the

395. A complete evaluation of the advantages and disadvantages to employees of the proposed amendments to section 129 requires consideration of state and local income tax rates as well as federal income tax rates. It also requires consideration of the immediate savings of Social Security taxes compared to potential reductions in Social Security benefits in the future, which are based on the employee's taxable earnings record. See supra notes 23,25 considering the tax treatment of employment-related child-care expenditures and social security.

396. Recent proposals for lowering corporate taxes for those businesses that provide their workers attractive compensation packages, including pensions, education and training, health insurance, and profitsharing or stock purchase, parallel the tax reform approach to child-care expenditures that I am suggesting. See Senate democratic Task force on High-Wage Jobs, Scrambling to Pay the Bllls: Butlding allies FOR AMERICA'S WORKING FAMILIES, PROPOSALS TO ADDRESS WAGE AND INCOME STAGNATION AND BOOST ECONOMC GROWTH 12-14 (Feb. 28, 1996) (modifying the Boren-Danforth Business Activities Tax proposal, which is a form of consumption tax); see also Margaret $\mathrm{O}$. Kirk, Parents, the Ultimate Experts, Critique the Clinton Proposal, N. Y. TIMES, Jan. 18, 1998, at 4 (describing President Clinton's child-care proposals, which include tax credits for companies that offer child-care services for employees); Nantell, supra note 11, at 92737 (describing state tax incentives to employers who provide child-care assistance to their employers); $i d$. at 950-51 (describing proposals to provide federal tax incentives to employers who furnish child-care assistance to employees).

397. See generally Handelman, supra note 231, at 135-36 (through analysis of health care costs, showing how U.S. tax policy has failed to recognize working people's lives and productive contributions with the effect that it has failed to account for the human costs of business enterprises through analysis of health care costs). 
workers of the future. The basis for this tax reform proposal is respect for the investment in human potential. Promotion of that respect is itself a necessary component to structural changes that will make the economic exploitation of child-care workers intolerable within our political economy. ${ }^{398}$

This proposal is likely to raise concerns on the part of the Internal Revenue Service and employers that they have neither the expertise nor the administrative systems necessary to evaluate the working conditions of child-care workers. Claims of complexity and unmanageability essentially reflect a general reluctance in the tax law to scrutinize business arrangements. Deference to the child-care labor market should be an unacceptable alternative, given its history and current operation. Before this proposal is rejected as unfeasible, the I.R.S. should at least have to show, after consulting with the business community, including small and large businesses, child-care experts, and labor relation experts, why it is unable to develop workable criteria for administering this tax provision.

The concern about the feasibility of the proposed employer-provided childcare assistance program raises a broader issue. The obvious criticism of the limited deduction/exclusion scheme that I am proposing is that it is explicitly designed to interfere with the marketplace and that such interference is inconsistent with the widely accepted goals of the federal income tax system. ${ }^{399}$ Standard tax analysis evaluates tax reform proposals based on their ability to avoid distorting economic decisions. If nothing else has been shown in this article, it is clear that there is no tax response that will not affect the child-care labor market. Regardless of the existence and/or extent of a deduction for employment-related child-care expenditures, the issue of economic exploitation of child-care workers cannot be avoided. A decision not to intervene in that economic exploitation is as significant as a decision to intervene. The goal of minimizing distorting economic decisions is based on an assumption that prices and wages are determined through competitive forces. Introducing the antisubordination principle into the discussion about the child-care labor market shows that this assumption was misplaced regarding this market sector. An argument to preserve the child-care labor market in the name of economic neutrality ignores the equally important goal that the tax law should not be used to facilitate class, gender, and race subordination.

The solution I am proposing to the complex set of problems concerning childcare is imperfect because it is produced out of a set of constrained circumstances that presents only bad choices. What is more important than the particulars of the proposal is that the discussion helps us to appreciate how the tax law is implicated in the social and economic relationships of the parties to an

398. I am encouraged to make this proposal by reports of the growing number of employers who are providing on-site child care for their employees. See Nantell, supra note 11, at 886, 946-48 (reporting that as of 1996 approximately 1400 businesses provided on-site child care). This development suggests a growing recognition by employees of their responsibility to this generation and future generations of employees.

399. See supra note 2 and accompanying text. 
economic arrangement. What the discussion of current tax law and possible reforms shows is that no tax debate about employment-related child-care expenditures should exclude consideration of how childcare has been constructed through our social and economic institutions. What the discussion further accomplishes is the removal of the artificial boundary between tax concepts designed to implement an ideal accretion tax and the social and economic environment in which those concepts operate. The point is not to diminish the importance of the distinction between business and personal or the concept of imputed income. Rather the point is that those concepts can gain more analytical power when they are analyzed within a framework that includes the antisubordination principle.

\section{CONCLUSION}

Through a historical examination of domestic work, specifically childcare, this article uncovers the class, gender, and race implications of the tax law's child-care provisions. In the process, this article shows how seemingly objective tax reasoning using seemingly objective principles of tax analysis implicates issues involving exploitative and subordinating practices. It further shows that when the principles prove inescapably problematic, stereotypical roles based on class, gender, and race are relied upon to obscure the inadequacy of the principles. Finally, it shows how those tax principles might be used in a much more dynamic fashion to further the dual goals of developing a comprehensive tax base and disrupting economic arrangements that lead to class, gender, and race subordination.

The analysis depends on the exploration of the meaning of domestic work and childcare over time and in various geographical contexts in the United States. Social and economic beliefs and practices frequently naturalize subordination. That is, beliefs and practices make subordination seem as though it is based on objective truth, leading to conclusions that the consequences of the subordination are fair, inevitable, unchangeable, or unrelated to the acquisition of wealth and status by others. ${ }^{400}$ The problem of identifying subordinating practices demands a methodology designed to contest theories, ideas, acts, or facts that are seemingly incontestable. The work of critical race theorists and legal feminists makes the difficult task of uncovering discrimination in the marketplace and in the tax law easier. This critical jurisprudence shows how important history is in providing a context for understanding current practices and beliefs. ${ }^{401}$ It also stresses the importance of examining relevant legal texts for rhetorical ploys that achieve the appearance of objectivity by relying on

400. See John O. Calmore, Critical Race Theory, Archie Schepp, and Free Music: Securing an Authentic Intellectual Life in a Multicultural World, 65 S. CAL. L. REV. 2129, 2142-44, 2206-10 (1992).

401. See id. at 2143-44; Cheryl I. Harris, Whiteness as Property, 106 HARV. L. REV. 1707, 1713-24, $1734-45(1993)$. 
subordinating beliefs and practices. ${ }^{402} \mathrm{I}$ am not suggesting that implementing the antisubordination principle is easy, but I am suggesting that the difficulties would be reduced if we expand traditional tax analysis by relying on a welldeveloped critical methodology, which historically contextualizes an issue and critically examines classic legal texts that have addressed that issue.

At first glance, attributing economic exploitation, sexism, and racism to the tax code may seem surprising. Admittedly, my linking of the income tax law and economic and social practices that lead to subordination of persons based on their class, gender, and race is not the standard fare of tax analysis. When policymakers address class issues, they typically do so in the context of evaluating tax reforms in terms of their distributional effects among income classes ${ }^{403}$ Seldom are tax rules evaluated by how they may maintain and perhaps encourage economic exploitation. ${ }^{404}$ In recent years, some academics have explored the ways in which the income tax law discriminates against women, in particular married women. ${ }^{405} \mathrm{~A}$ few have discussed the ways in which income tax law treats same-sex couples. ${ }^{406}$ Far too little analysis has been published exploring the implications of race in tax law. ${ }^{407}$ This growing collection of work,

402. See, e.g., Lucinda M. Finley, Breaking Women's Silence in Law: The Dilemma of the Gendered Nature of Legal Reasoning, 64 NOTRE DAME L. REV. 886, 887-95 (1989); Harris, supra note 401, at 1750-57.

403. See, e.g., STAFF OF JONT COMM. ON TAXATION, supra note 2, at 16-18; STAFF OF JONT ECONOMI CoMm., supra note 2, at 34-40; Anne L. Alstott, The Earned Income Tax Credit and the Limitations of TaxBased Welfare Reform, 108 HARV. L. REV. 533, 557-58 (1995); Barbara H. Fried, Fairness and the Consumption Tax, 44 STAN. L. REV. 961, 1011-12 (1992); Heen, supra note 382, at 189-90; Weiss, supra note 263 , at 239-40; Zelenak, supra note 6, at 369-70.

404. But see generally, e.g., Handelman, supra note 231 (showing how tax analysis fails to recognize the productive role of workers); Roy, supra note 232 (interrogating the soundness of the personal/business distinction and revealing how the distinction privileges the business realm while devaluing the contributions of workers and their families).

405. See, e.g., MCCAFFERY, supra note 30, at 11-28; Alstott, supra note 9, at 2006-50; Amy C Christian, The Joint Return Rate Structure: Identifying and Addressing the Gendered Nature of the Tax Law, 23 J. L. \& POL. 241, 279-354 (1997); Alice Kessler-Harris, "A Principle of Law But Not of Justice": Men, Women and Income Taxes in the United States 1913-1948, 6 S. CAL. REV. L. \& WOMEN's STUD. 331, 349-60 (1997); Marjorie E. Komhauser, Love, Money, and the IRS: Family, Income-Sharing, and the Joint Income Tax Return, 45 HASTNGS L.J. 63, 92-111 (1993); Edward J. McCaffery, Slouching Towards Equality: Gender Discrimination, Market Efficiency, and Social Change, 103 YALE L.J. 595, 600-34 (1993); McCaffery, supra note 18, at 988-96, 1001-29; Zelenak, supra note 254, at 344-81, 401-04.

406. See, e.g., Patricia A. Cain, Taxing Lesbians, 6 S. CAL. REV. L. \& WOMEN's STUD. 471, 475-81 (1997) (demonstrating how for unmarried couples the tax law is in many cases unclear and in other cases is generally disadvantageous); Patricia A. Cain, Same-Sex Couples and the Federal Tax Laws, 1 LAW \& SEXUALITY 97, $111-23$ (1991) (analyzing the tax treatment of same-sex couples); Adam Chase, Tax Planning for Same-Sex Couples, 72 DENV. U. L. REV. 359, 360-68 (1995) (comparing tax treatment of same-sex couples and married couples); William V. Vetter, Restrictions on Equal Treatment of Unmarried Domestic Partners, 5 B.U. PUB. INT. L.J. 1, 5-12 (1995) (analyzing tax ramifications of domestic partnerships).

407. But see Brown, supra note 146, at 1488-1507 (compiling income data for married couples based on race showing that the marriage penalty produced by the joint return in disproportionately paid by low- and middle-income white wives and African American wives and that the marriage bonus is disproportionately enjoyed by upper-income white wives); Brown, supra note 196, at 52-54 (evaluating the joint tax return and providing data showing that white couples are more likely to enjoy the marriage bonus and Black couples are more likely to suffer the marriage penalty); Beverly I. Moran \& William Whitford, A Black Critique of the Internal Revenue Code, 1996 WIS. L. REV. 751, $759-803$ (studying the differential enjoyment of various tax benefits by Blacks and whites); john a. powell, How Government Tax and Housing Policy Have Racially Segregated America, in TAXING AMERICA, supra note 196, at 80, 92-95 (analyzing how the role of the federal government, including its tax policies, has contributed to racial separation of African American and white 
however, is not viewed as central to an understanding of the basic concepts of tax law. ${ }^{408}$ This article attacks the myth that considerations of class, gender, and race raise tangential tax issues, and shows that tax analysis cannot be done in the absence of an antisubordination principle.

Policymakers widely accept that the federal tax law should be designed to meet the goals of equity, administrability, and economic rationality. ${ }^{409}$ They have pursued these goals predominantly through a technical lens, seeking neutral and objective solutions. ${ }^{410}$ Their attempts to disengage normative questions from technical ones have led to a cramped view of what constitutes equity, administrability, and economic neutrality as well as to policies that hinder redistributive justice.

Under traditional tax analysis, it is easy to forget that the three goals of the federal tax law are embedded in American political values, which include respect for individual autonomy, privacy, and free enterprise. For example, a tax rule that requires a taxpayer to reveal or allow government inspection of information generally viewed as personal is considered unadministrable because it would lack public support. Freedom from governmental intervention in an individual's private life is a strong American political value that carries considerable weight in debates about current tax law and proposed reforms, even if not consistently reflected in existing tax laws.

Another strongly held American value reflected in these goals is a commitment against discrimination on the basis of class, gender, and race. ${ }^{411}$ No one advocates, for example, tax rules that explicitly tax members of the working class more than capitalists, women more than men, or persons of color more than whites. ${ }^{412}$ Although some argue that legal remedies aimed at reducing discrimination are ineffective and lead to economic inefficiencies, ${ }^{413}$ no one

communities)

408. See Karen B. Brown \& Mary Louise Fellows, Introduction to TAXnNG AMERICA, supra note 196, at 2 (discussing the current debate on tax reform and how it fails to take into account issues of class, gender, and race).

409. See STAFF of JoInt COMM. ON TAXATION, supra note 2, at 6-11; STAFF OF JOINT ECONOMIC COMM., supra note 2, at 30-42.

410. See Lisa Philipps, Discursive Deficits: A Feminist Perspective on the Power of Technical Knowledge in Fiscal Law and Policy, 11 CAN. J.L. \& SOC'Y 141, 145, 149-51 (1996).

411. The same cannot be said with as much conviction about discrimination based on disabilities or sexual orientation.

412. Progressive taxation might be described as reflecting class animus against the wealthy. This is not, however, a rebuttal to the argument in the text because the animus is directed at a group-the wealthy-that historically and contextually wield considerable economic and social power. Animus toward the wealthy does not perpetuate domination but disrupts it and should not be equated with animus toward members of the working class.

413. See, e.g., Richard A. Epsten, ForbidDen Grounds: The Case Against EMPloyment Discrimination Laws 28-87 (1992); Daniel R. Fischel \& Edward P. Lazear, Comparable Worth and Discrimination in Labor Markets, 53 U. CH. L. REV. 891, 901-15 (1986); Richard A. Posner, An Economic Analysis of Sex Discrimination Laws, 56 U. CHI. L. REV. 1311, 1325-34 (1989). For examples of legal scholars favoring legal intervention, see Mary E. Becker, Barriers Facing Women in the Wage-Labor Market and the Need for Additional Remedies: A Reply to Fischel and Lazear, 53 U. CHI. L. REV. 934, 940-47 (1986); John J. Donohue III, Prohibiting Sex Discrimination in the Workplace: An Economic Perspective, 56 U. CHI. L. REV. 1337, 1358-68 (1989). 
advocates that the law should be designed to exacerbate marketplace discrimination. ${ }^{414}$ Policymakers should oppose vigorously any such proposal as inconsistent with all three goals of the federal tax system that follow from the American belief in assuring individual dignity and equal opportunity.

They should view the antisubordination principle as merely an extension of the current tradition of evaluating tax law in terms of its redistributive effects. Although progressivity frequently is contested ${ }^{415}$ tax proposals are typically debated in terms of their distributional effects among income classes. ${ }^{416}$ Agreement with the antisubordination principle is not a prerequisite to its inclusion in tax policy discussions. What is necessary is consensus that a comprehensive tax analysis includes an evaluation of whether a tax provision perpetuates or disrupts class, gender, and race subordination.

An analytical framework that combines traditional tax principles with the antisubordination principle proved fruitful when applied to childcare. Its ultimate potential is still undetermined. Other specific topics in the tax law need to be examined to uncover the various ways that tax literature reinforces differential treatment based on class, gender, and race. The topics should also be analyzed to determine how our understanding of tax provisions might change through an examination of the historical context in which the relevant economic arrangements occur. In addition, a similar analysis needs to be undertaken for the more general tax structural rules, such as the realization principle, accrual and cash accounting, and the non-taxation of imputed income from services and property. Once some of this work is accomplished, we may begin to imagine the general outlines of a tax system that embraces the goal of a comprehensive tax base while furthering this country's aspirations and policies to prevent economic exploitation and promote equality.

414. For a similar analysis of the tax law, see McCaffery, supra note 405, at 597-98.

415. See Charles O. Galvin \& Boris I. BTTKER, ThE Income TAX: How Progressive Should IT BE? 14-21, $31-58$ (1969); Joseph Bankman \& Thomas Griffith, Social Welfare and the Rate Structure: A New Look at Progressive Taxation, 75 CAL. L. REV. 1905, 1910-45 (1987); Donna M. Byme, Progressive Taxation Revisited, 37 ARI. L. REV. 739, 742-71 (1995); Marjorie E. Komhauser, The Rhetoric of the AntiProgressive Income Tax Movement: A Typical Male Reaction, 86 Mich. L. REV. 465, $470-517$ (1987); Charles R. O'Kelley, Jr., Tax Policy for Post-Liberal Society: A Flat-Tax-Inspired Redefinition of the Purpose and Ideal Structure of a Progressive Income Tax, 58 S. CAL. L. REV. 727, 728-35 (1985).

416. See, e.g., Adam Clymer, White House and the G.O.P. Announce Deal to Balance Budget and to Trim Taxes, N.Y. TIMES, July 29, 1997, at A1; Jason DeParle, Democrat's Invisible Man Specializes in Making Inequity to Poor Easy to See, N.Y. TIMES, Aug. 19, 1991, at Al2; E. J. Dionne, Jr., For Richer, for Poorer, In Taxes and Ideology, N.Y. TIMES, Aug. 22, 1986, at A10; Peter G. Gosselin, Soaking the Rich? Or Just a Return to Pre-Reagan Days?, Boston GLOBE, Oct. 17, 1990, § National/Foreign, at 1; Steven Greenhouse, Clinton's Economic Plan: Impact on Individuals; Middle Class and Wealthy to Bear Brunt of New Taxes, N.Y. TIMES, Feb. 18, 1993, at A18; Sylvia Nasar, Who Paid the Most Taxes in the 80's? The Superrich, N.Y. TMES, May 31, 1992, § 3, at 4; Peter Passell, Level Field or Uneven Results? Tallying Up the What Ifs in the Flat-Tax Proposals, N.Y. TIMES, Feb. 16, 1996, at D2; Robert Pear, Focus on the Tax Package: Who Will Pay How Much?, N.Y. TamES, Oct. 4, 1990, at D22; Tom Redburn, Tax Hikes to Hit the Poor, Middle Class, L.A. TIMES, Oct. 3, 1990, at Al; Robert J. Shapiro, Flat Wrong: New Tax Schemes Can't Top Old Progressive Truths, WASH. PosT, Mar. 24, 1996, § Outlook, at CO3; Robin Toner, Major Help Found in Tax Bill for Low-Income Households, N.Y. TIMES, Aug. 22, 1986, at Al. 